\title{
ÆUSGS
}

science for a changing world

In Cooperation with Coast Salish Nation

\section{Coast Salish and U.S. Geological Survey 2009 Tribal Journey Water-Quality Project}

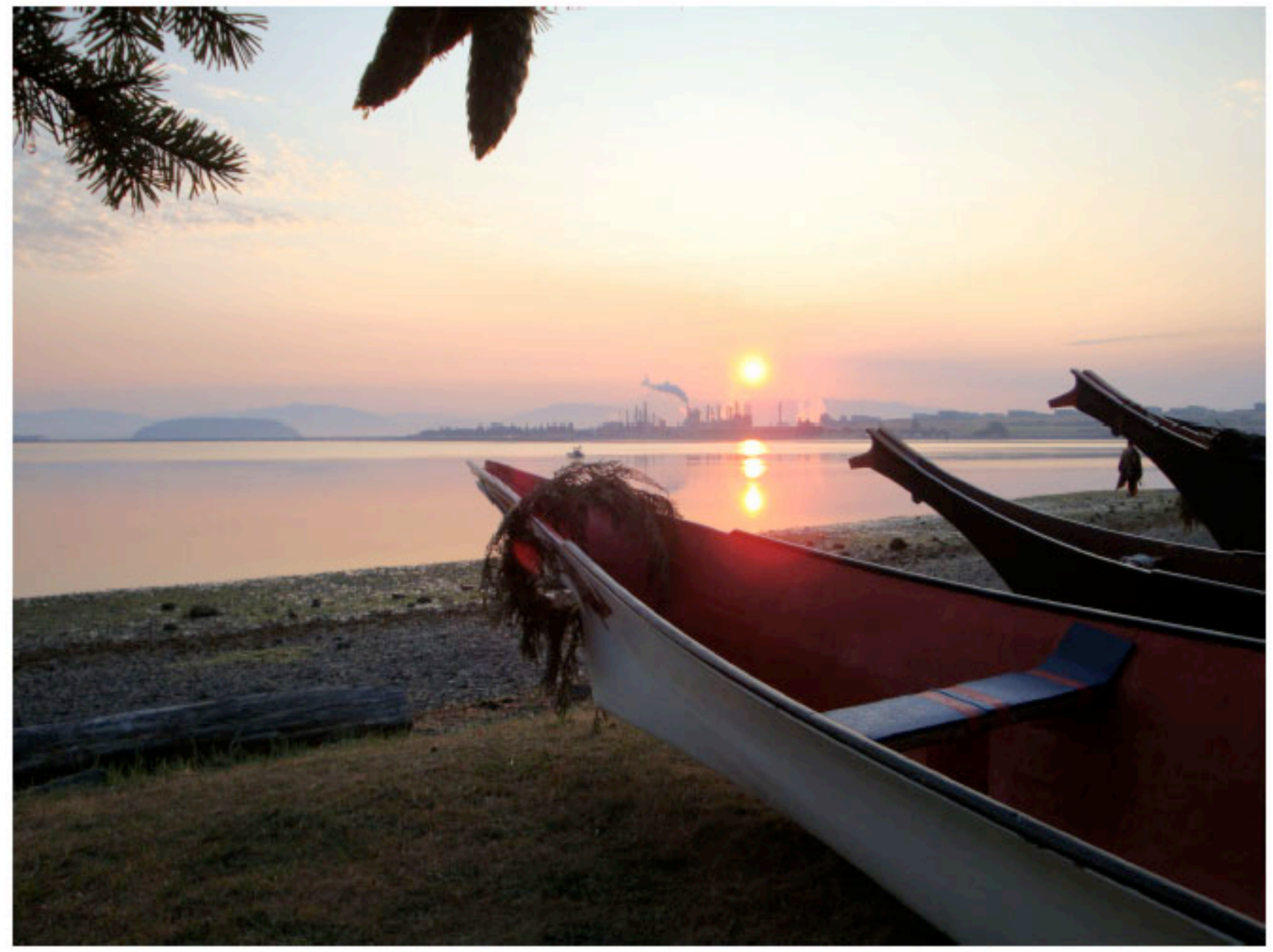

Open-File Report 2010-1143 
COVER:

This photograph is looking at a sunrise over the March's Point from the Samish canoe landing near Anacortes, Washington. Photo by Eric E. Grossman 


\section{Coast Salish and U.S. Geological Survey 2009 Tribal Journey Water-Quality Project}

By Sarah K. Akin and Eric E. Grossman

Prepared in cooperation with the

Coast Salish Nation

Open-File Report 2010-1143

U.S. Department of the Interior

U.S. Geological Survey 


\title{
U.S. Department of the Interior \\ KEN SALAZAR, Secretary
}

\author{
U.S. Geological Survey \\ Marcia K. McNutt, Director
}

U.S. Geological Survey, Reston, Virginia: 2010

For product and ordering information:

World Wide Web: http://www.usgs.gov/pubprod

Telephone: 1-888-ASK-USGS

For more information on the USGS-the Federal source for science about the Earth,

its natural and living resources, natural hazards, and the environment:

World Wide Web: http://www.usgs.gov

Telephone: 1-888-ASK-USGS

Suggested citation:

Akin, S.K., and Grossman, E.E., 2010, Coast Salish and U.S. Geological Survey 2009 Tribal Journey water quality project: United States Geological Survey Open-File Report 2010-1143, 60 p. [http://pubs.usgs.gov/of/2010/1143/].

Any use of trade, product, or firm names is for descriptive purposes only and does not imply endorsement by the U.S. Government.

Although this report is in the public domain, permission must be secured from the individual copyright owners to reproduce any copyrighted material contained within this report. 


\section{Contents}

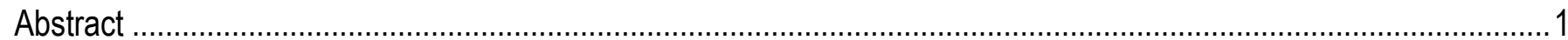

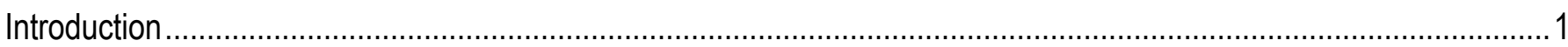

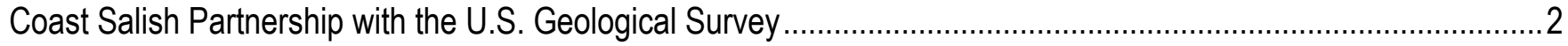

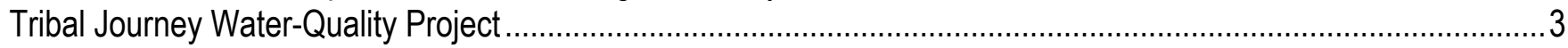

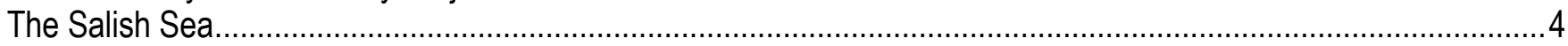

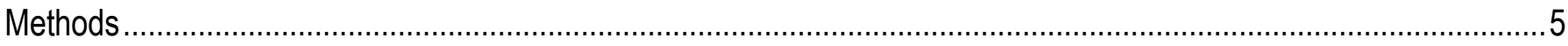

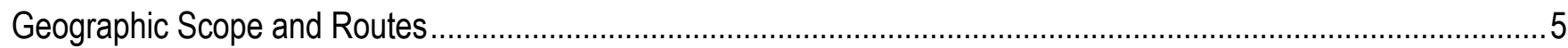

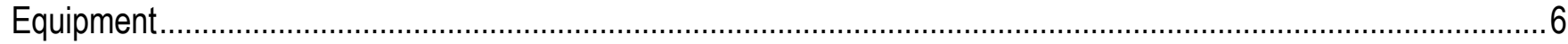

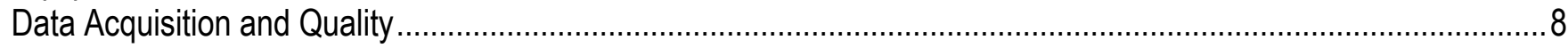

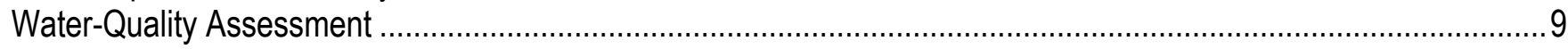

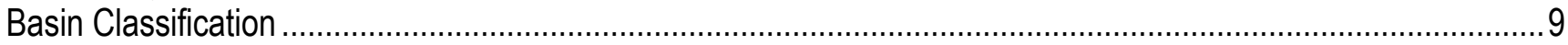

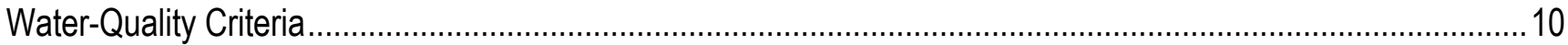

Results

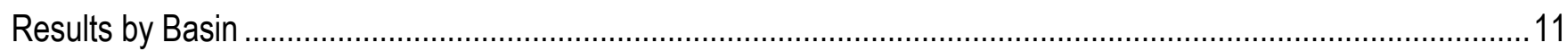

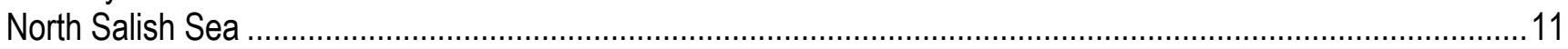

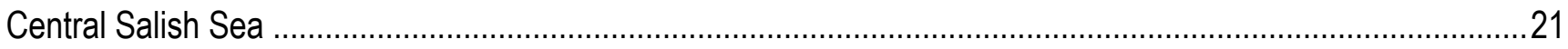

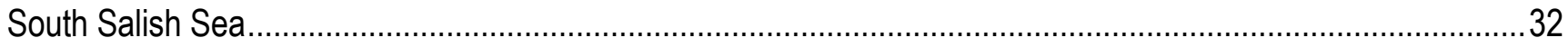

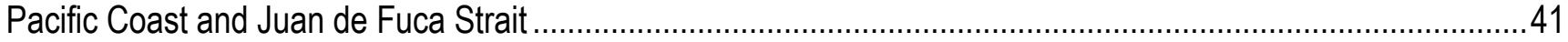

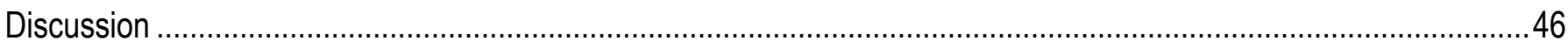

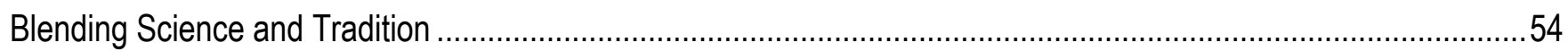

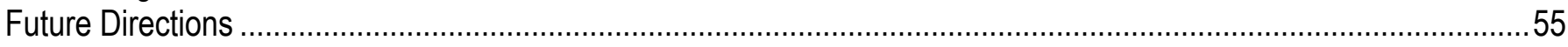

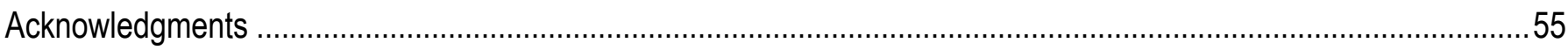

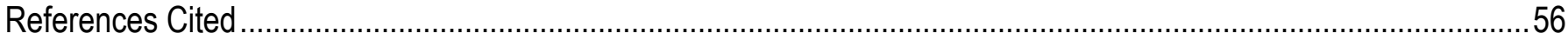

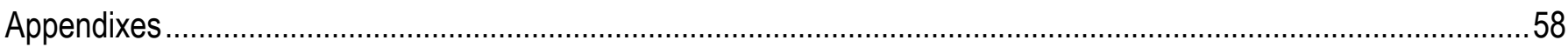

Appendix I: YSI 6920 V2-2 Sensor specifications including units, range, resolution, and accuracy.........................58

Appendix II: Calibration and Audit Log recording the accuracy of conductivity, pH, turbidity, and

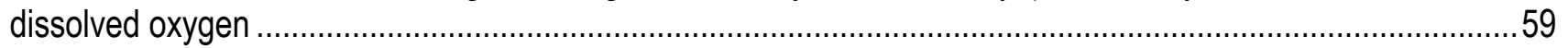

\section{Figures}

Figure 1. The Salish Sea with 2008 (white) and 2009 (yellow) monitoring routes with basin outlines, landing sites and reporting regions, United States and Canada. Salish Sea watershed boundary (white) adapted from Environment Canada... 3

Figure 2. Squamish Nation canoe towing a YSI sonde during the 2009 Tribal Journey. Photo by E. Grossman. ..........6

Figure 3. YSI sonde and cables with the Pelican watertight housing. Photo by L. Gordon....................................... 8

Figure 4. Red algae bloom observed in Squamish Basin north of Horseshoe Bay and east of Anvil Island, British Columbia, Canada. Photo by E. Grossman

Figure 5. Discharge measurements in cubic meters per second and temperature in degrees Celsius for the Fraser River at Hope, British Columbia, Canada, from June 1 to October 1, 2009. Yellow box indicates time period canoes traveled through the Fraser River and delta. Data Collected by Environment Canada.

Figure 6. Surface-water temperatures recorded in degrees Celsius in the northern portion of the Salish Sea from July 22 to 24, 2009. This region includes data from Squamish and Lower Fraser Basins and the Fraser River.....

Figure 7. Surface-water salinity results recorded in practical salinity units in the northern portion of the Salish Sea from July 22 to 24, 2009. This region includes data from Squamish and Lower Fraser Basins and the Fraser River. 
Figure 8. Surface-water $\mathrm{pH}$ recorded in standard units in the northern portion of the Salish Sea from July 22 to 24, 2009. This region includes data from Squamish and Lower Fraser Basins and the Fraser River.

Figure 9. Surface-water dissolved oxygen recorded in milligrams per liter in the northern portion of the Salish Sea from July 22 to 24, 2009. This region includes data from Squamish and Lower Fraser Basins and the Fraser River......

Figure 10.Surface-water turbidity recorded in Formazin Nephelometric Units in the northern Salish Sea from July 22 to 24, 2009. This region includes data from Squamish and Lower Fraser Basins and the Fraser River.......19

Figure 11. Daily river discharge in cubic meters per second for the Skagit River at Mt. Vernon, Wash. (Station 12200500). The yellow box indicates the time period that the canoes pulled past the Skagit delta. Data collected by the U.S. Geological Survey.

Figure 12. Surface-water temperature recorded in degrees Celsius in the central Salish Sea from July 21 to August 4, 2009. This region includes results from the San Juan, Whidbey, and North Central Puget Sound and from the Skagit River.

Figure 13. Surface-water salinity recorded in practical salinity units in the central Salish Sea from July 21 to August 4, 2009. This region includes results from the San Juan, Whidbey, and North Central Puget Sound and from the Skagit River.....

Figure 14. Surface-water pH recorded in standard units in the central Salish Sea from July 21 to August 4, 2009. This region includes results from the San Juan, Whidbey, and North Central Puget Sound and from the Skagit River.

Figure 15. Surface-water dissolved oxygen recorded in milligrams per liter in the central Salish Sea from July 21 to August 4, 2009. This region includes results from the San Juan, Whidbey, and North Central Puget Sound and from the Skagit River.

Figure 16. Surface-water turbidity recorded in Formazin Nephelometric Units along the central Salish Sea from July 21 to August 4, 2009. This region includes results from the San Juan, Whidbey, and North Central Puget Sound and from the Skagit River.

Figure 17. Biological growth observed in South Central Basin, August 2009. Photo by E. Grossman. 33

Figure 18. Surface-water temperature recorded in degrees Celsius in the southern Salish Sea region from July 21 to August 3, 2009. This region includes results from the Hood Canal, South Central Puget Sound, and South Puget Sound Basins.

Figure 19. Surface-water salinity recorded in practical salinity units in the southern Salish Sea region from July 21 to August 3, 2009. This region includes results from the Hood Canal, South Central Puget Sound, and South Puget Sound Basins.

Figure 20. Surface-water pH recorded in standard units in the southern Salish Sea region from July 21 to August 3, 2009. This region includes results from the Hood Canal, South Central Puget Sound, and South Puget Sound Basins.

Figure 21. Surface-water dissolved oxygen recorded in milligrams per liter in the southern Salish Sea region from July 21 to August 3, 2009. This region includes results from the Hood Canal, South Central Puget Sound, and South Puget Sound Basins.

Figure 22. Turbidity recorded in Formazin Nephelometric Units in the southern Salish Sea region from July 21 to August 3, 2009. This region includes results from the Hood Canal, South Central Puget Sound, and South Puget Sound Basins.

Figure 23. Surface-water temperature $(A)$ recorded in degrees Celsius and salinity $(B)$ recorded in practical salinity units in the west Salish Sea from July 26 to 29, 2009. This region includes results from the Pacific Coast and Juan de Fuca Basins.

Figure 24. Surface-water $\mathrm{pH}(\mathrm{A})$ recorded in standard units and dissolved oxygen (B) recorded in milligrams per liter in the west Salish Sea from July 26 to 29, 2009. This region includes results from the Pacific Coast and Juan de Fuca Basins. 
Figure 25. Surface-water turbidity measured in Formazin Nephelometric Units in the west Salish Sea from July 26 to 29, 2009. This region includes results from the Pacific Coast and Juan de Fuca Basins.

Figure 26. Surface-water temperature (in degrees Celsius) by basin in the Salish Sea, 2008 and 2009, for marine water bodies and fresh water. Basins are arranged from furthest north (left) to furthest south (right), followed by oceanic and fresh water inputs. Numbers above plots are the average temperature for each basin.

Figure 27. Dissolved-oxygen concentrations by basin in the Salish Sea, 2008 and 2009. Basins are arranged from furthest north (left) to furthest south (right), followed by oceanic and fresh water inputs to the Salish Sea. $\mathrm{NaN}$ indicates no data.

Figure 28. Temperature, dissolved oxygen, and pH by basin for the Salish Sea, 2008 and 2009. Basins are arranged from north (left) to south (right), followed by fresh water inputs from Fraser River.

Figure 29. Elevated temperatures associated with shallow embayments monitored by the TJWQP. A, Samish Bay $B$, Port Susan C, Fraser River delta D, Port Gamble, Wash. E, South Puget Sound and Hood Canal.

Figure 30. Water properties offshore of East Bay south of Orcas Island in the San Juan Islands. $A$ temperature in degrees Celsius, $B \mathrm{pH}$ in $\mathrm{pH}$ units, and $C$ dissolved oxygen in milligrams per liter

\section{Tables}

Table 1. Landing starting locations, number of days traveled, start and end travel dates, number of kilometers traveled and the YSI model number used by the Canoe families during the 2009 Tribal Journey to Suquamish, Washington.

Table 2. Instrument accuracy and audit criteria for conductivity, dissolved oxygen, pH, and turbidity, 2009 Tribal Journey to Suquamish, Washington.....

Table 3. Data flags used during data processing, 2009 Tribal Journey to Suquamish, Washington.

Table 4. Basin codes created by the Puget Sound Nearshore Ecosystem Restoration group and the British Columbia Watershed Atlas group.

Table 5. Washington State aquatic-life criteria for $(A)$ marine surface -waters temperatures, $(B)$ dissolved oxygen, and $(\mathrm{C}) \mathrm{pH}$

Table 6. Water-quality statistics from Squamish and Lower Fraser Basins, 2009...............................................2 20

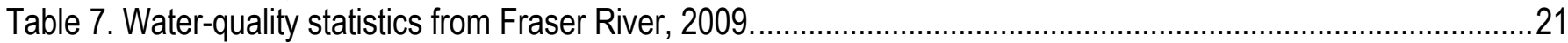

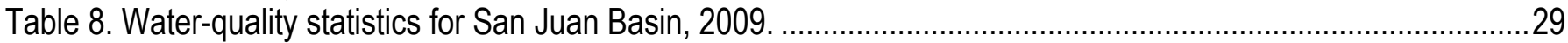

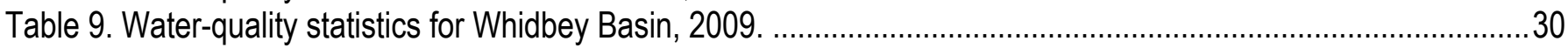

Table 10. Water-quality statistics for North Central Basin and Skagit River, 2009.................................................31

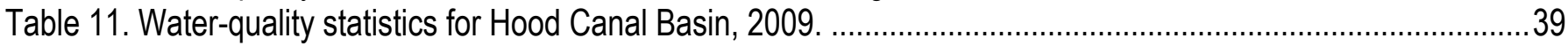

Table 12. Water-quality statistics for South Central and South Sound Basins, 2009.............................................40

Table 13. Water-quality statistics for Pacific Coast and Juan de Fuca Basins, 2009 ............................................45

Table 14. Average temperature and dissolved-oxygen classifications in the Salish Sea, 2008 and 2009.

Classifications are based on Washington State water quality criteria extraordinary, excellent, good, and fair quality aquatic life uses (table 4). 


\section{Conversion Factors}

\begin{tabular}{|lcl|}
\hline \multicolumn{1}{|c|}{ Multiply } & \multicolumn{1}{c|}{ To obtain } \\
\hline & Length & \\
\hline kilometer $(\mathrm{km})$ & 0.6214 & mile $(\mathrm{mi})$ \\
\hline meter $(\mathrm{m})$ & 3.281 & foot $(\mathrm{ft})$ \\
\hline & Area & \\
\hline square kilometer $\left(\mathrm{km}^{2}\right)$ & 0.3861 & square mile $\left(\mathrm{mi}^{2}\right)$ \\
\hline
\end{tabular}

Temperature in degrees Celsius $\left({ }^{\circ} \mathrm{C}\right)$ may be converted to degrees Fahrenheit ( $\left.{ }^{\circ} \mathrm{F}\right)$ as follows:

${ }^{\circ} \mathrm{F}=\left(1.8 \times^{\circ} \mathrm{C}\right)+32$

Specific conductance is given in microsiemens per centimeter at 25 degrees Celsius $\left(\mu \mathrm{S} / \mathrm{cm}\right.$ at $\left.25^{\circ} \mathrm{C}\right)$. 


\title{
Coast Salish and U.S. Geological Survey 2009 Tribal Journey Water-Quality Project
}

\author{
By Sarah K. Akin and Eric E. Grossman
}

\begin{abstract}
The Salish Sea, contained within the United States and British Columbia, Canada, is the homeland of the Coast Salish Peoples and contains a diverse array of marine resources unique to this area that have sustained Coast Salish cultures and traditions for millennia. In July 2009, the Coast Salish People and U.S. Geological Survey conducted a second water quality study of the Salish Sea to examine spatial and temporal variability of environmental conditions of these surface waters as part of the annual Tribal Journey. Six canoes of approximately 100 towed multi parameter water-quality sondes as the Salish People traveled their ancestral waters during the middle of summer. Sea surface temperature, salinity, $\mathrm{pH}$, dissolved oxygen, and turbidity were measured simultaneously at ten-second intervals, and more than 54,000 data points spanning 1,300 kilometers of the Salish Sea were collected. The project also synthesized Coast Salish ecological knowledge and culture with scientific monitoring to better understand and predict the response of coastal habitats and marine resources. Comparisons with data collected in 2008 reveal significantly higher mean surface-water temperatures in most subbasins in 2009 linked to record air temperatures that affected the Pacific Northwest in July 2009. Through large-scale spatial measurements collected each summer, the project helps to identify patterns in summer water quality, areas of water-quality impairment, and trends occurring through time.
\end{abstract}

\section{Introduction}

In July 2009, the Coast Salish People and U.S. Geological Survey (USGS) conducted a second water-quality study of the Salish Sea to investigate the Coast Salish ancestral waters and the response of coastal environments to climate change and land-use impacts. The ancestral waters of the Coast Salish People, the Salish Sea, constitute a large inland sea contained within the United States (Puget Sound) and British Columbia, Canada (Georgia Strait). The Salish Sea is home to more than 220 species of fish, 29 species of marine mammals, more than 40 species of commercially and recreationally harvested invertebrates, and numerous resident and migratory bird species (Washington Sea Grant Program, 2000). Unfortunately, at least 60 of these marine-based species are listed as threatened, endangered or of concern (Fraser and others, 2006). Many of these species sustained Coast Salish for millennia and are of essential cultural importance. Forecasts of climate change and urban population increase across the Pacific Northwest suggest that the Salish Sea may experience significant change in ways we do not fully understand and are not currently able to predict.

Human activities and climate change are impacting coastal ecosystems and accelerating the loss of ecologically and culturally important marine resources. Watershed modifications, coastal development, and industrial activities are altering river and tidal flow, sediment transport, and nutrient delivery all across the region, leading to the breakdown of ecosystem functions and decreasing biodiversity throughout the Salish Sea. A cooperative transboundary partnership between the U.S. Environmental 
Protection Agency (USEPA) and the Government of Canada has identified a number of key Salish Sea indicators of health, several that are noted to be worsening, including marine water-quality conditions; river, stream, and lake water quality; number of marine species at risk; toxics in harbor seals; and increased urbanization and forest change (U.S. Environmental Protection Agency, 2008). The Salish Sea ecosystem is threatened by expanding anoxic zones, invasive species that commonly exploit degraded ecosystem conditions, and changes in climate (for example, precipitation, lower river base flows). The complexities of monitoring, protecting, and restoring such a large and diverse geographical area are exacerbated by the fact that the region extends across a major political boundary, the border between the United States and Canada and one characterized by significant daily exchange of water and suspended materials by strong oceanographic circulation.

In response to the deterioration of coastal environments and the need for quantitative information on the spatial and temporal variability in water-quality conditions and physical processes influencing water quality (Puget Sound Partnership, 2008), the Coast Salish People and USGS have commenced on a partnership to examine water quality throughout the Georgia Strait and Puget Sound. This partnership measures, analyzes, and reports on water-quality conditions across the Salish Sea and synthesizes traditional Coast Salish ecological knowledge with scientific monitoring to better understand and predict the response of essential coastal habitats and marine resources to climate and human-induced change. The foundation of the study consists of measuring water-quality parameters simultaneously behind multiple (five or six) ocean-going canoes during the annual Tribal Journey, during which canoe families traveling the ancestral highways celebrate and share their rich culture. Water-quality sondes towed by the canoes collect surface-water samples every 10 seconds, producing quantitative water-property characterizations at high-resolution and across an extensive area of the Salish Sea. Special studies, including time-series moorings, depth profiling of water quality, and studies of nutrients and plankton biology in water samples, provide additional context for the canoe-track results and information on processes influencing water-quality. This time period of middle summer is important to understand conditions when environmental stress is high owing to peak annual air and seasurface temperatures, low river flow and high productivity.

During the 2008 Tribal Journey to Cowichan five Coast Salish canoes carrying YSI sondes collected more than 40,000 data points along different routes covering nearly 600 kilometers $(\mathrm{km})$ of Salish Sea territory. In 2009, canoe track studies were repeated and additional science activities were implemented, including (1) depth profiling of major water-quality parameters to examine vertical variability, (2) discrete sampling of surface waters for analyses of dissolved nutrients and phytoplankton-community composition, and (3) mooring deployments to measure variability of waterquality parameters through time associated with diurnal changes and tidal mixing. This report describes the activities and results from the canoe-based water-property measurements made during the 2009 Coast Salish Tribal Journey.

\section{Coast Salish Partnership with the U.S. Geological Survey}

We Are Coast Salish

"We, the indigenous peoples of the Salish Sea, our autonomous status as sovereign Tribes and First Nations and our inherent responsibility as protectors of our Mother Earth, will continue to speak with One Voice for the preservation, restoration, and protection of the Salish Sea Eco Region for the sustainability of our sacred inherent family rights and values that have been passed on to us by our ancestors" - Coast Salish Gathering Mission Statement

The Salish Sea is the homeland of the Coast Salish Peoples and contains a diverse and unique array of marine and upland resources unique to this area that sustain Coast Salish cultures and traditions.

Salmon are the icon of this essential but endangered connection of Coast Salish People to their land and 
waters. Coast Salish homelands and resources are under significant pressure from population growth, industrial expansion and economic demands.

In February 2008, the idea of mapping the surface-water quality of the Salish Sea during the annual Tribal Journey, the concept of the Tribal Journey Water Quality Project (TJWQP), was presented to Coast Salish Leaders at the third annual Coast Salish Gathering in Tulalip, Wash. (Akin and others, 2009). With unanimous approval, the TJWQP was formally adopted by the Coast Salish Gathering leadership. It is the first scientific effort to come out of the Coast Salish Gathering.

The objectives of the TJWQP are (1) to strengthen the valuable partnership between Coast Salish and the USGS to enhance environmental science and monitoring throughout the Salish Sea; (2) to integrate the scientific expertise provided by USGS with traditional means to gather and synthesize information on impacts to water quality, nearshore habitats, and marine resources; and, (3) to share and integrate traditional ecological knowledge with modern science and technologies to promote awareness and stewardship of the Salish Sea. The information collected during the annual Tribal Journeys will support Coast Salish leadership in making policy decisions regarding Salish Sea resources, as well as inform the scientific community and public of emerging issues concerning coastal ecosystems and climate change.

No other environmental-monitoring agency sponsored by the States, Provinces, or Federal governments of the United States or Canada has been able to spatially sample transboundary waterways as extensively as the TJWQP. The commitment of the participating canoe families made this unique effort possible.

\section{Tribal Journey Water-Quality Project}

The TJWQP blends of state-of-the-art science with the unique sampling opportunity provided by the annual Tribal Canoe Journey to measure surface water quality throughout several basins across the vast area of the Salish Sea (fig. 1). Coast Salish canoe families, in traditional canoes traveling principal ancestral waterways, simultaneously measure sea-surface temperature, salinity, $\mathrm{pH}$, turbidity, and dissolved oxygen using multiparameter water-quality sondes with Global Positioning System (GPS) every 10 -seconds while paddling canoes along various water bodies spanning hundreds of kilometers of Puget Sound, Georgia Basin, and the Pacific Coast.

The Tribal Journey occurs every summer from July through the first week of August, and each year a different final landing destination is chosen. In 2009 the final destination for the canoes was Suquamish territory in Suquamish, Wash. Although the destination is a different final landing each year, principal ancestral pathways are followed annually, enabling repeated sampling of those portions of the Salish Sea. During the 2008 and 2009 journeys, the TJWQP demonstrated that high-resolution waterquality science could be done using these methods. The data collected provide a baseline for water quality across the Salish Sea, the ability to identify areas of water-quality impairment, and trends in water properties over time. The identification of impaired water masses can be used to guide additional intensive studies to improve understanding of patterns and drivers of the impairment. Though the project currently is done only in the summer during the annual Tribal Journey, comparisons between years highlight variability in water properties across the Salish Sea during this time of high environmental stress. These data can be compared to other data sets and to future surveys to form a more complete picture of the state of the Salish Sea and of water quality trends in space and time. 


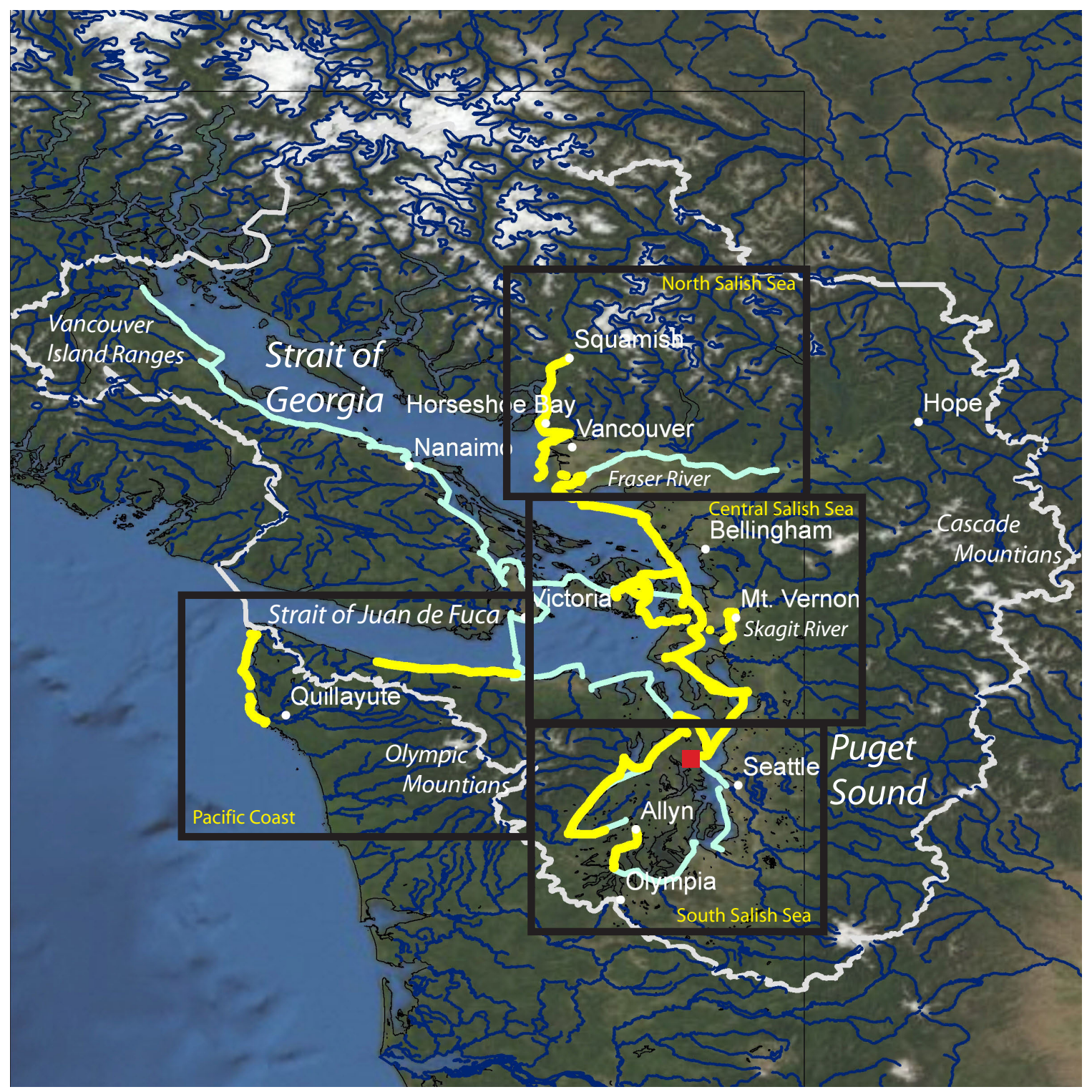

Figure 1. The Salish Sea with 2008 (white) and 2009 (yellow) monitoring routes with basin outlines, landing sites and reporting regions, United States and Canada. Salish Sea watershed boundary (white) adapted from Environment Canada.

With the success of the 2008 and 2009 journeys, planning is underway for the 2010 journey, with the intention of continuing to build water-quality monitoring capacity among Coast Salish communities. The TJWQP could not have been done without the foundational partnerships between the Coast Salish leadership, Coast Salish canoe families, and the USGS.

\section{The Salish Sea}

The Salish Sea has a surface area of $16,925 \mathrm{~km}^{2}$ with $7,470 \mathrm{~km}$ of coast line. At its deepest point, the depths reach $270 \mathrm{~m}$ (SeaDoc, 2008). The Salish Sea watershed is outlined by the crests of the Olympic Mountains, Vancouver Island Ranges, and the Cascade Mountains and covers roughly $135,000 \mathrm{~km}^{2}$ (Fraser and others, 2006). The Fraser and Skagit Rivers are the largest 
freshwater sources to the Salish Sea. The Fraser River accounts for 25 percent of the total freshwater input to Georgia Strait. The Skagit River supplies 35 percent of total freshwater input to Puget Sound. These two rivers support runs of all five species of Pacific salmon (Environment Canada, 2000) and are considered critical for their recovery throughout the entire Salish Sea ecosystem (Puget Sound Partnership, 2008).

\section{Methods}

This section describes the protocols and development of the methods used during the TJWQP. Coordination with canoe families, determination of routes, equipment, data acquisition and quality, water-quality assessment, and water-quality criteria are discussed.

\section{Geographic Scope and Routes}

The planning process for the Tribal Journey takes place within the individual Canoe Families and at Canoe Skippers planning meetings hosted monthly by various Tribes and First Nations around the region. The Canoe Families carefully create the yearly routes, which follow the traditional pathways of their ancestors through the Salish Sea. The official routes are not finalized in some cases until a few weeks before the Tribal Journey is set to begin. The TJWQP does not attempt to influence the planning process because the TJWQP is an added component to, not a driver of, the Tribal Journey. After the Tribal Journey routes have been established, sections to be used for the TJWQP are chosen according to two main criteria: (1) routes traveling the greatest extent of Salish Sea, and (2) willingness of the Canoe Families to participate in the Project.

The Canoe Families that participated in the 2008 TJWQP were Squaxin Island (Shelton, Wash.), Swinomish Tribe (LaConner, Wash.), the Sto:lo People (Chillawack, BC), Homalco Nation (Campbell River, BC), and the Skokomish Tribe (Skokomish, Wash.). In 2009, six tribal canoes participated in the water-quality monitoring, traveling from their home territories toward the final destination at Suquamish, Wash. The Squaxin Island and Swinomish tribes participated in the project for a second year and were joined by Squamish Nation (Vancouver, BC), Quinault Nation (Taholah, Wash.), Songhees Nation (Victoria, BC) and the Blue Heron canoe representing the Duwamish Tribe (Seattle, Wash.). The survey began July 22, 2009, and was completed August 3, 2009. Table 1 summarizes the landing sites for each of the 2008 and 2009 monitoring routes.

Table 1. Landing starting locations, number of days traveled, start and end travel dates, number of kilometers traveled and the YSI model number used by the Canoe families during the 2009 Tribal Journey to Suquamish, Washington.

\begin{tabular}{|l|c|c|c|c|c|c|}
\hline & \multicolumn{7}{|c|}{ Canoe Family } \\
\cline { 2 - 7 } & Squaxin Island & Squamish & Swinomish & Quinault & Blue Heron & Songhees \\
\hline Starting Location & Nisqually & Howe Sound & Birch Bay & LaPush & Deception Pass & Victoria \\
\hline Travel Days & 5 & 9 & 5 & 2 & 5 & 1 \\
\hline Start Date & $7-27-2009$ & $7-22-2009$ & $7-28-2009$ & $7-26-2009$ & $7-21-2009$ & $7-29-2009$ \\
\hline End Date & $8-3-2009$ & $7-31-2009$ & $8-4-2009$ & $7-29-2009$ & $7-26-2009$ & $7-29-2009$ \\
\hline $\begin{array}{l}\text { Distance in } \\
\text { kilomaters }\end{array}$ & 298 & 574 & 205 & 135 & 154 & 35 \\
\hline $\begin{array}{l}\text { YSI Model } \\
\text { Number }\end{array}$ & $6600 \mathrm{~V} 2$ & $6600 \mathrm{~V} 2$ & $6920 \mathrm{~V} 2$ & $6920 \mathrm{~V} 2$ & $6920 \mathrm{~V} 2$ & $6920 \mathrm{~V} 2$ \\
\hline
\end{tabular}


Canoe skippers typically plan the timing of daily trips to follow the tide from one location to another. Departure times and trip durations depend on the distance between landing sites, weather conditions, currents, and the pulling ability of the Canoes' crew. During the 2009 Journey the tide regime was characterized by early morning and late afternoon high tides, so a large proportion of the samples were collected during falling tides.

\section{Equipment}

Water-quality measurements were made by towing water-quality sondes behind traditional Coast Salish canoes. Canoes are ideal platforms for conducting surface-water-quality testing because they minimize disturbance and contamination of the water common with motorized boats. Canoes also move slowly and steady through the water at a pace between 3 to $9 \mathrm{~km} / \mathrm{hr}$ (2 to $6 \mathrm{mi} / \mathrm{hr}$ ) allowing collection of densely spaced data (fig. 2).

Water-quality data were collected using YSI Environmental model 6600 or 6920 V2 sondes towed within the top half meter of the water column. Both the YSI 6600 and 6920 recorded temperature [degrees Celsius $\left({ }^{\circ} \mathrm{C}\right)$ ], salinity [practical salinity units (psu)], $\mathrm{pH}$ (pH units), dissolved-oxygen concentration [milligrams per liter $(\mathrm{mg} / \mathrm{L})$ ], dissolved-oxygen percent saturation $(\% \mathrm{sat})$, and turbidity (FNU). YSI 6600 sondes used on two routes, Squamish, and Squaxin Island, also recorded chlorophyll fluorescence [relative fluorescence units (RFU)] and dissolved oxygen with a rapid-pulse probe. The YSI 6920 V2 optical port was equipped with optical ROX dissolved oxygen. Specifications for all sensors are provided in appendix I. The main water-quality parameters of interest for this report are surface-water temperature, dissolved oxygen (concentration and percent saturation), salinity, $\mathrm{pH}$, and turbidity.

YSI sondes were calibrated and audited daily to ensure data accuracy and to correct for any instrument drift. Calibration and audit procedures were performed by the water-quality technicians according to manufacturer recommendations. Quality-control procedures for acceptance or rejection of data are described in the USGS National Field Manual for the Collection of Water-Quality Data (Wilde, 2005) and were reviewed by USGS water-quality specialists (Akin and others, 2009). Data are accepted or rejected based on the determined acceptable precision drift range (table 2). The calibration and audit table can be found in appendix II.

Data collected by the YSI sondes were logged onto high memory YSI 650 display units that were connected to the sonde using a field cable. Garmin GPS units, boosted by a Garmin GA 25MCX antennae, also were connected to the YSI 650 display using a YSI 6115 GPS cable to integrate position information directly into the YSI data files. Sondes and displays were synchronized to GPS time prior to deployment to ensure uniformity in the data between the different tracks. The display and GPS units were housed in a water-tight Pelican case using watertight cable clams (fig. 3). The sonde and Pelican cases containing logging equipment were fixed to the aft of the canoe using shock cord. Sondes were kept inside the canoes until after the launching ceremony and then deployed when the canoe began each day's journey. The measurements made every 10 seconds, translated to an average spacing on the water of $\sim 20 \mathrm{~m}$ ( $75 \mathrm{ft}$ ) given the average speed of the traveling canoes. 


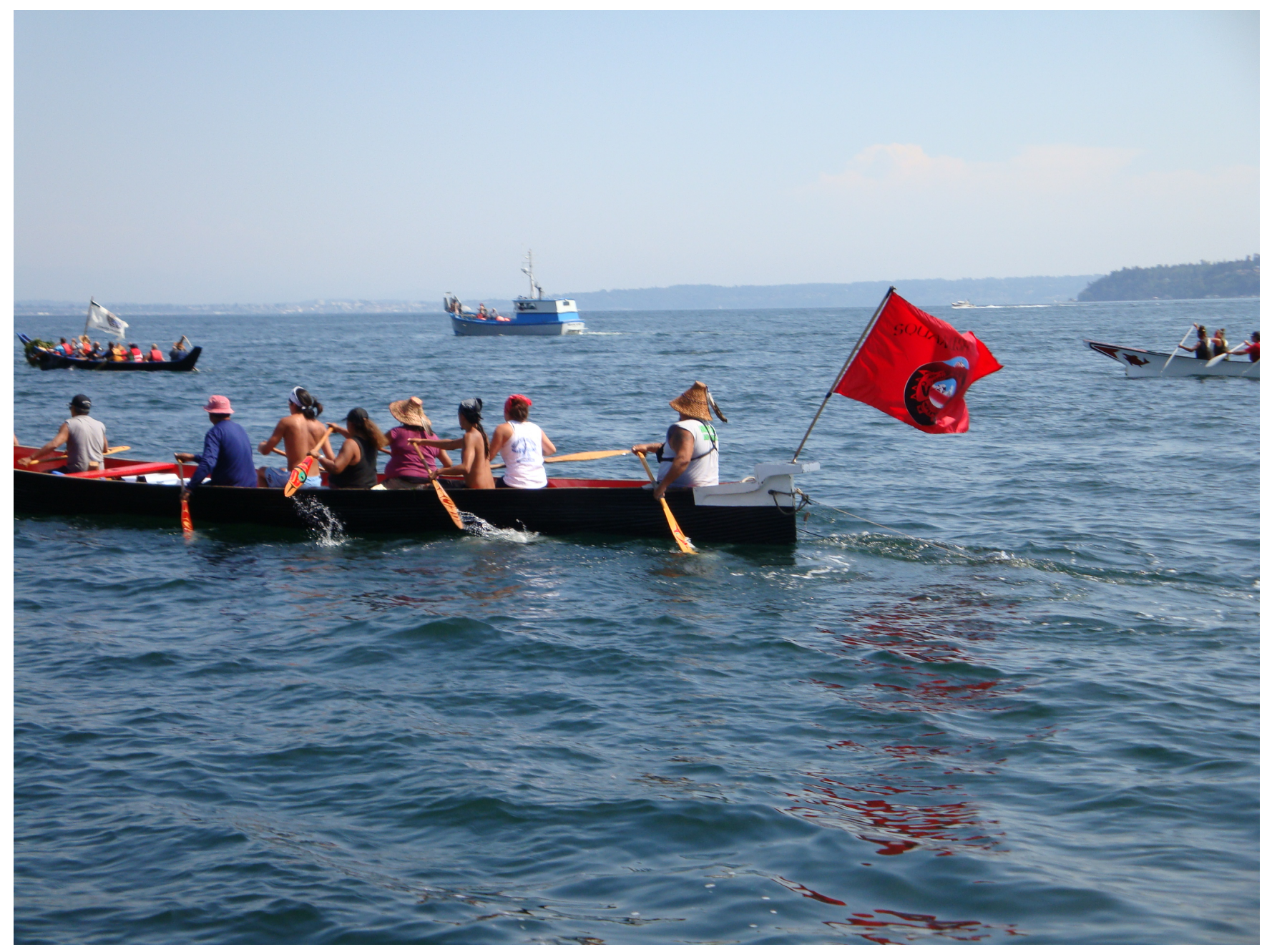

Figure 2. Squamish Nation canoe towing a YSI sonde during the 2009 Tribal Journey. Photo by E. Grossman. 


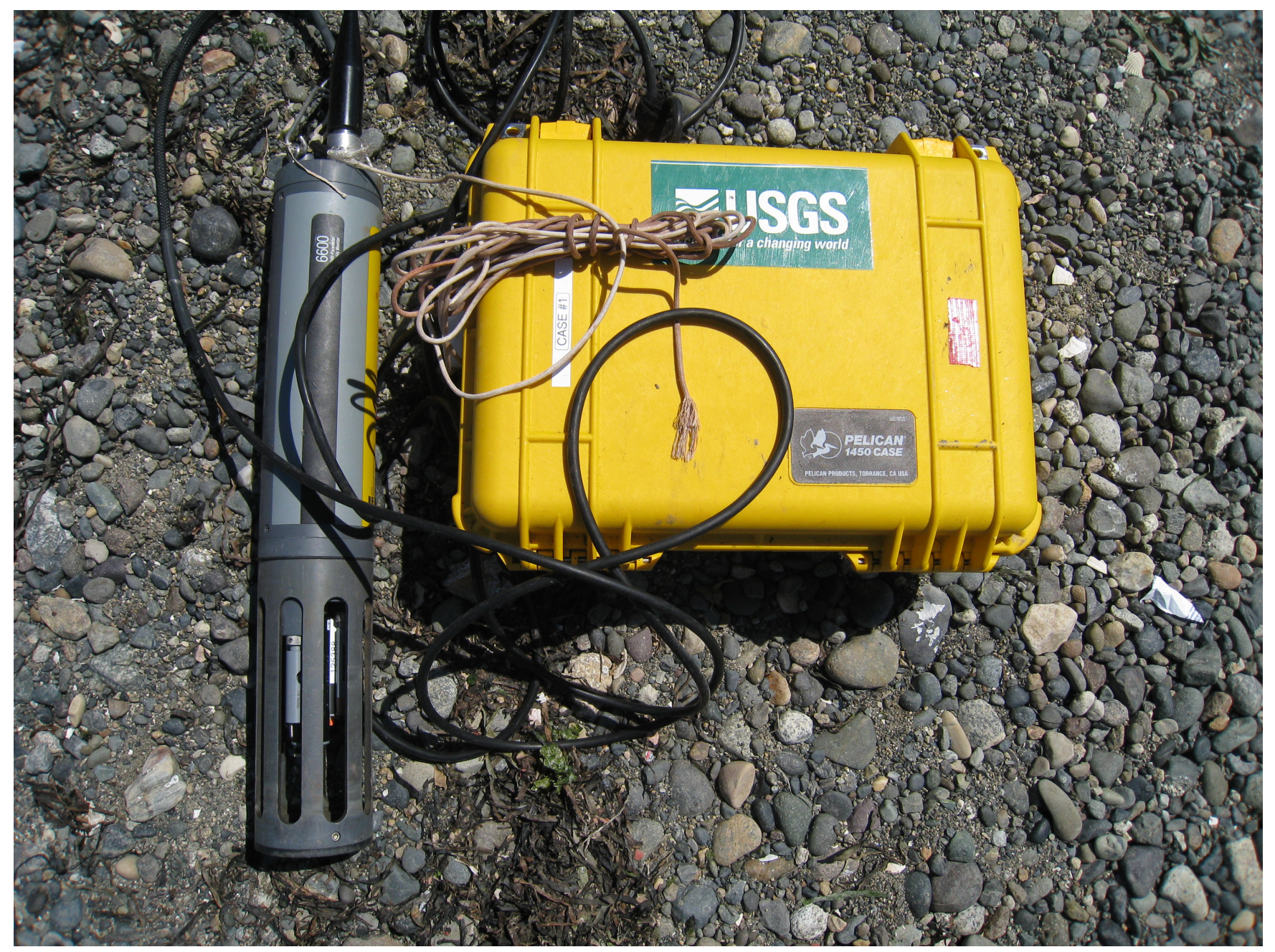

Figure 3. YSI sonde and cables with the Pelican watertight housing. Photo by L. Gordon.

\section{Data Acquisition and Quality}

The data presented in this report were gathered during USGS Field Activity C-2-09-PS (http://walrus.wr.usgs.gov/infobank/c/c209ps/html/c-2-09-ps.meta.html). To assist with sonde and sensor maintenance and with quality-assurance and control procedures, each canoe family welcomed a water-quality technician on their journey. Technicians were selected for their experience with waterquality testing equipment and/or for their experiences working with Tribes and First Nations. It was very important that the Canoe Families accept the technician as a part of their Family and that the technicians ensure that the TJWQP did not interfere with the cultural and healing aspects of the Tribal Journey. The Technicians also had to be comfortable with being on the open water for six or more hours at a time and physically capable of pulling their fair share of each canoe leg, which can be strenuous for even the most fit paddler.

Data processing procedures were modified for the 2009 field effort based on results of the 2008 project. Raw YSI data files were downloaded each day and processed according to the following steps: (1) raw track data files were merged with the 10-second interval corresponding GPS file containing latitude, longitude, and speed; (2) calibration and audit logs were examined for each of the instruments for each of the days to determine which parameters met data-quality objectives (table 2); (3) errors in 
the merged data files were flagged with a numerical codes (table 3); and (4) flagged data errors were corrected, where possible, before files proceeded for subsequent analyses.

Table 2. Instrument accuracy and audit criteria for conductivity, dissolved oxygen, pH, and turbidity, 2009 Tribal Journey to Suquamish, Washington.

\begin{tabular}{|l|c|c|c|}
\hline Parameter & Units & Method Accuracy & Precision \\
\hline Conductivity & $\mathrm{mS} / \mathrm{cm}$ & $\pm 0.5 \%$ of reading & $\pm 0.3 \mathrm{~ms} / \mathrm{cm}$ \\
\hline Dissolved Oxygen & $\mathrm{mg} / \mathrm{L}$ & $\pm 0.2 \mathrm{mg} / \mathrm{L}$ & $\pm 0.5 \mathrm{mg} / \mathrm{L}$ \\
\hline $\mathrm{pH}$ & $\mathrm{pH}$ units & \pm 0.2 units & \pm 0.2 units \\
\hline Turbidity & $\mathrm{FNU}$ & $2 \%$ of range & $5 \%$ of range \\
\hline
\end{tabular}

Table 3. Data flags used during data processing, 2009 Tribal Journey to Suquamish, Washington.

\begin{tabular}{|l|l|}
\hline Flag & Criteria \\
\hline-1111 & delete out of water (zero salinity) \\
\hline-2222 & delete zero value latitude/longitude \\
\hline-3333 & correct positive value longitude \\
\hline-4444 & zero negative turbidity values \\
\hline-5555 & zero negative chlorophyll values \\
\hline-6666 & salinity sensor error \\
\hline-9999 & failed parameter audit or probe error \\
\hline
\end{tabular}

Following initial quality-control processing, data were mapped in Google Maps and disseminated near real-time online at the Project Web site (http://www.usgs.gov/coastsalish). Maxima, minima, mean and standard deviation for each parameter were analyzed, except for $\mathrm{pH}$, where the median was determined.

\section{Water-Quality Assessment}

\section{Basin Classification}

The Salish Sea is consists of three main water bodies: Puget Sound, the Strait of Georgia, and the Strait of Juan de Fuca. The Puget Sound Nearshore Ecosystem Restoration Project (PSNERP) divided Puget Sound into seven basins that take into account the diversity in bathymetry and circulation features across the region (Shipman, 2008). However, this basinclassification system only addresses the portion of the Salish Sea within Washington State. To add areas in British Columbia and the Strait of Georgia, six watershed groups (Lower Fraser River, Squamish, Comox, Parker, Cowichan, and Victoria, hereafter referred to as basins) were used from the British Columbia Watershed Atlas (British Columbia, 2007). The borders of these basins were extended seaward to include the marine waters offshore of the watersheds. TJWQP data were classified by the 16 designated basins by using GIS software with basin names used for marine water bodies and water body names used for the fresh water bodies of the Fraser and Skagit Rivers that were monitored during the Tribal Journey (table 4). 
Table 4. Basin codes created by the Puget Sound Nearshore Ecosystem Restoration group and the British Columbia Watershed Atlas group.

\begin{tabular}{|l|l|}
\hline Basin Code & Basin Name \\
\hline COMX & Comox \\
\hline PARK & Parksville \\
\hline COWN & Cowichan \\
\hline SQUM & Squamish \\
\hline LFRA & Lower Fraser \\
\hline VICT & Victoria \\
\hline SJ & San Juan \\
\hline JF & Juan de Fuca \\
\hline WB & Whidbey \\
\hline NC & North Central Puget Sound \\
\hline SC & South Central Puget Sound \\
\hline HC & Hood Canal \\
\hline SP & South Puget Sound \\
\hline PC & Pacific Coast \\
\hline Fraser & Fraser River \\
\hline Skagit & Skagit River \\
\hline
\end{tabular}

\section{Water-Quality Criteria}

We compared the data with an established set of regulatory standards to evaluate the variation in the water quality across the study area. Washington State has developed water-quality standards through the Washington Administrative Code to protect the marine and fresh surface waters of the State, with specific levels of protection designated by quality of aquatic life uses for marine surface waters. Marine waters are classified as being of extraordinary quality, excellent quality, good quality, and fair quality as outlined in Washington Administrative Code Title 173-201 A, 2006 (table 5). The marine surfacewater results by basin from the TJWQP were compared to wac-173-201A-210 standards, and results for temperature, dissolved oxygen, and $\mathrm{pH}$ are reported in this document.

Table 5. Washington State aquatic-life criteria for $(A)$ marine surface -waters temperatures, $(B)$ dissolved oxygen, and $(C) \mathrm{pH}$.

\begin{tabular}{|c|c|}
\hline Aquatic Life Use & General Description \\
\hline Extraordinary quality & $\begin{array}{l}\text { Salmonid and other fish migration, rearing, and spawning; clam, oyster, and mussel } \\
\text { rearing and spawning; crustaceans and other shellfish (crabs, shrimp, crayfish, scallops, } \\
\text { etc.) rearing and spawning. }\end{array}$ \\
\hline Excellent quality & $\begin{array}{l}\text { Salmonid and other fish migration, rearing, and spawning; clam, oyster, and mussel } \\
\text { rearing and spawning; crustaceans and other shellfish (crabs, shrimp, crayfish, scallops, } \\
\text { etc.) rearing and spawning. }\end{array}$ \\
\hline Good quality & $\begin{array}{l}\text { Salmonid migration and rearing; other fish migration, rearing, and spawning; clam, oyster, } \\
\text { and mussel rearing and spawning; crustaceans and other shellfish (crabs, shrimp, } \\
\text { crayfish, scallops, etc.) rearing and spawning. }\end{array}$ \\
\hline Fair quality & Salmonid and other fish migration. \\
\hline
\end{tabular}




\begin{tabular}{|c|c|c|}
\hline \multicolumn{3}{|c|}{$\begin{array}{l}\text { Aquatic Life Temperature and Dissolved Oxygen Criteria in Marine Water } \\
\text { WAC-173-201A-210 Table } 210(1)(c) \text { and }(d)\end{array}$} \\
\hline Category & $\begin{array}{l}\text { Highest 1-Day Maximum, in } \\
\text { degrees Celsius }\end{array}$ & $\begin{array}{l}\text { Lowest 1-Day Minimum, in } \\
\text { milligrams per liter }\end{array}$ \\
\hline $\begin{array}{l}\text { Extraordinary } \\
\text { quality }\end{array}$ & $13\left(55.4^{\circ} \mathrm{F}\right)$ & 7 \\
\hline Excellent quality & $16\left(60.8^{\circ} \mathrm{F}\right)$ & 6 \\
\hline Good quality & $19\left(66.2^{\circ} \mathrm{F}\right)$ & 5 \\
\hline Fair quality & $22\left(71.6^{\circ} \mathrm{F}\right)$ & 4 \\
\hline
\end{tabular}

C

Aquatic Life pH Criteria in Marine Water WAC-173-201A-210 Table 210 (1)(f)

\begin{tabular}{|l|l|}
\hline Use Category & \multicolumn{1}{c|}{$\mathrm{pH}$ Units } \\
\hline Extraordinary quality & $\begin{array}{l}\mathrm{pH} \text { must be within the range of } 7.0 \text { to } 8.5 \text { with a human-caused } \\
\text { variation within the above range of less than } 0.2 \text { units. }\end{array}$ \\
\hline Excellent quality & $\begin{array}{l}\mathrm{pH} \text { must be within the range of } 7.0 \text { to } 8.5 \text { with a human-caused } \\
\text { variation within the above range of less than } 0.5 \text { units. }\end{array}$ \\
\hline Good quality & Same as above. \\
\hline Fair quality & $\begin{array}{l}\mathrm{pH} \text { must be within the range of } 6.5 \text { to } 9.0 \text { with a human-caused } \\
\text { variation within the above range of less than } 0.5 \text { units. }\end{array}$ \\
\hline
\end{tabular}

\section{Results}

The data results presented in this report summarize the water-quality patterns of the Salish Sea in 2009 and provide comparisons to the 2008 results (Akin and others, 2009) at the landscape scale and basin scale. Site-specific patterns in a subset of both data years are available online at http://www.usgs.gov/coastsalish/.

A total of 54,522 data points were collected during the 2009 Tribal Journey, capturing surface-water temperature, dissolved-oxygen concentration and percent saturation, $\mathrm{pH}$, salinity, and turbidity. The six canoes pulling during the TJWQP covered 1,366 km of the Salish Sea during the two week period from July 21 to August 4, 2009.

\section{Results by Basin}

The Canoe Families that participated in the TJWQP came from territories at the furthest extents of the Salish Sea from the final landing in Suquamish. The results of their efforts are summarized by sub-basin within four regions of the Salish Sea (north, central, south, and Pacific regions, fig. 1), with corresponding summary maps for surface-water temperature, salinity, $\mathrm{pH}$, turbidity, and dissolved oxygen.

\section{North Salish Sea}

Within the north region of the Salish Sea, the Squamish (SQUM) and Lower Fraser (LFRA) Basins and the Fraser River (Fraser) are examined. The canoes traveled through Squamish Basin on July 22 and 23, the Lower Fraser Basin on the afternoons of July 23 and 24, and the Fraser River on July 24, 2009. Temperature, salinity, $\mathrm{pH}$, dissolved oxygen, and turbidity results for the north Salish Sea are provided in figures 6 to 10; tabulated results for the contributing basins (Squamish and Lower Fraser Basins and Fraser River) are in tables 6 and 7. 
Freshwater inputs from the Squamish and Fraser Rivers play a major role in regional variation in the water-quality properties measured by the TJWQP in the SQUM and LFRA Basins. Surface-water temperatures in the Squamish Basin (table 6) were cool during 2009 in northern Howe Sound and warmed during the day as the canoes traveled toward Horseshoe Bay. During the two-day sampling period the temperature ranged from 11.97 to $22.36^{\circ} \mathrm{C}$ and the average was $18.4^{\circ} \mathrm{C}(\mathrm{n}=4,946)$. A surface plume of freshwater in Squamish Basin depressed the salinities, resulting in a minimum of $0.5 \mathrm{psu}$, a maximum of $27 \mathrm{psu}$ and an average of $11 \mathrm{psu}(\mathrm{n}=4,057)$. The $\mathrm{pH}$ results ranged widely from 6.8 units at the northern extent of Howe Sound to 9.1 units in the southern portion of the basin approaching Vancouver. The median $\mathrm{pH}$ was 8.29 units $(\mathrm{n}=4,946)$ and nearly 24 percent of $\mathrm{pH}$ samples were above 8.5 units, contributing to the fair water-quality classification for $\mathrm{pH}$ for the basin. Dissolved-oxygen concentration ranged from 7.9 to $16.9 \mathrm{mg} / \mathrm{L}$ and averaged $10.8 \mathrm{mg} / \mathrm{L}(\mathrm{n}=4,946)$. The dissolved-oxygen saturation for Squamish Basin ranged from a minimum of 93.6 percent toa maximum of 208.3 percent and averaged 124.2 percent. The high dissolved-oxygen concentrations were observed by project staff while traveling through a red algae bloom that extended more than $11 \mathrm{~km}$ (fig. 4). The dissolvedoxygen concentrations measured qualified Squamish Basin for extraordinary water quality during the monitoring, which all occurred during daylight hours. Turbidity showed a minimum of $0.0 \mathrm{FNU}$, a maximum of $180 \mathrm{FNU}$ and an average of $13 \mathrm{FNU}(\mathrm{n}=4,946)$.

Between July 23 and July 25, $2009(\mathrm{n}=1,956)$ Lower Fraser Basin (table 6) surface-water temperatures ranged from 12.2 to $23.5^{\circ} \mathrm{C}$, and averaged $17.5^{\circ} \mathrm{C}$. Surface-water temperature cooled, moving south from the city of Vancouver, BC, across the Fraser Delta front and into the deeper waters offshore of the delta. Due to a brief period of equipment malfunction, salinity was measured only in Lower Fraser Basin on the afternoon of July 24 on a transect from the river mouth toward the delta front. The salinity ranged from 0.0 to $22 \mathrm{psu}$ and averaged $3.9 \mathrm{psu}(\mathrm{n}=207)$. The $\mathrm{pH}$ in Lower Fraser Basin ranged from 7.5 to 8.5 units (median of $8.1, n=1,968$ ). Dissolved-oxygen concentration reached a maximum of 13.8 and a minimum of $6.3 \mathrm{mg} / \mathrm{L}$ and averaged $8.7 \mathrm{mg} / \mathrm{L}(\mathrm{n}=1,827)$. Dissolved-oxygen saturation levels reached a maximum of 181.6 percent, reflecting high surface-water productivity during the calm, warm weather conditions that prevailed during sampling. Turbidity values ranged from 0.0 to $91 \mathrm{FNU}$, and averaged $8 \mathrm{FNU}(\mathrm{n}=1,968)$ for the Lower Fraser Basin.

The Fraser River discharge recorded by Environment Canada at the Hope, British Columbia, station decreased from a peak of 7,500 cubic meters per second $\left(\mathrm{m}^{3} / \mathrm{s}\right)$ in mid June to $4,000 \mathrm{~m}^{3} / \mathrm{s}$ (fig. 5) in late July when the canoes were monitoring marine waters offshore of the Fraser delta. At the Hope monitoring station, located about $150 \mathrm{~km}$ from the delta, water temperatures were about $17.9{ }^{\circ} \mathrm{C}$ during the monitoring period and peaked a week later near $20^{\circ} \mathrm{C}$ (fig. 5). TJWQP temperature monitoring in the lower reach of the Fraser River (table 7) showed a minimum of $18.3^{\circ} \mathrm{C}$, a maximum of $26.4^{\circ} \mathrm{C}$, and averaged $19.3^{\circ} \mathrm{C}(\mathrm{n}=914)$. These results show an $8.5^{\circ} \mathrm{C}$ increase in water temperature from the Hope station to the delta. Surface waters of the Fraser River on July 24, 2009, were of fair water quality for all the samples collected. Fraser River salinity ranged from 0.1 to 5.8 psu near the delta, and averaged 1.0 psu. The median $\mathrm{pH}$ was 7.8 units with a range of 7.7 to 8.4 units. Dissolved-oxygen levels ranged from 8.6 to $10.0 \mathrm{mg} / \mathrm{L}$ and averaged $9.1 \mathrm{mg} / \mathrm{L}$. Dissolved-oxygen percent saturation ranged from 96.3 to 124.5 percent. Turbidity levels were elevated in the Fraser River, ranging from 3.9 to $89 \mathrm{FNU}$ and averaging 29 FNU. 


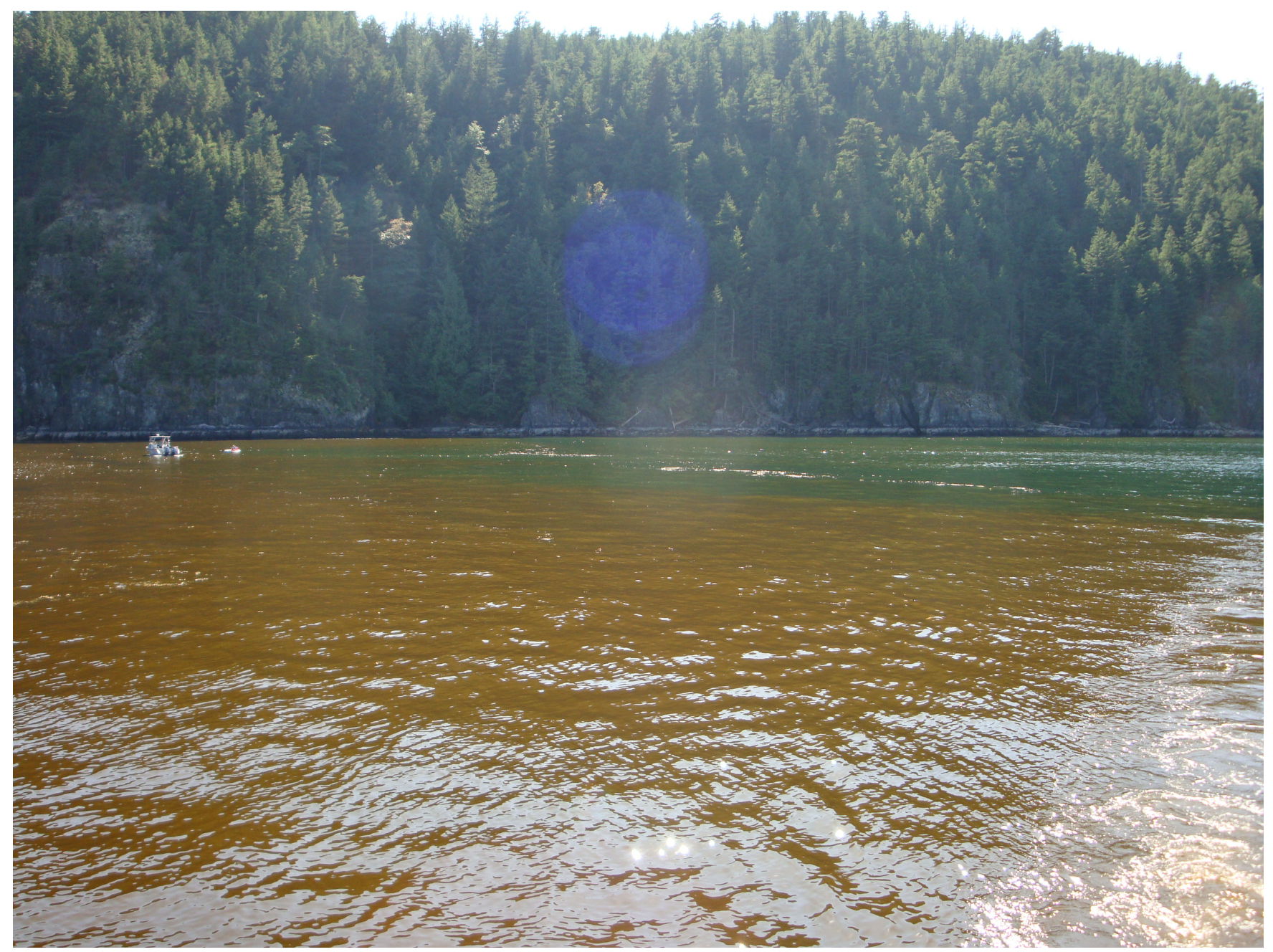

Figure 4. Red algae bloom observed in Squamish Basin north of Horseshoe Bay and east of Anvil Island, British Columbia, Canada. Photo by E. Grossman. 


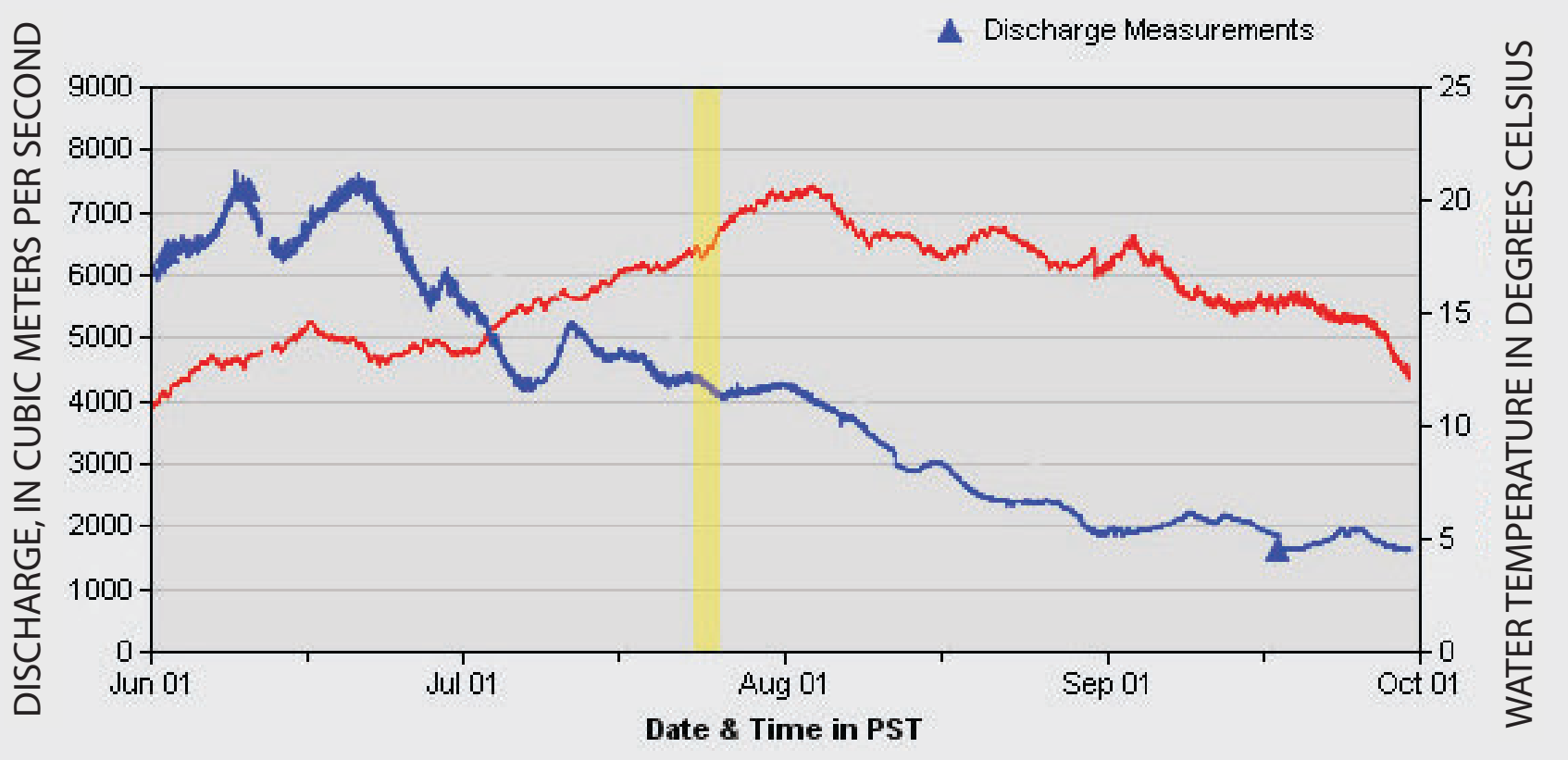

Figure 5. Discharge measurements in cubic meters per second and temperature in degrees Celsius for the Fraser River at Hope, British Columbia, Canada, from June 1 to October 1, 2009. Yellow box indicates time period canoes traveled through the Fraser River and delta. Data Collected by Environment Canada. 


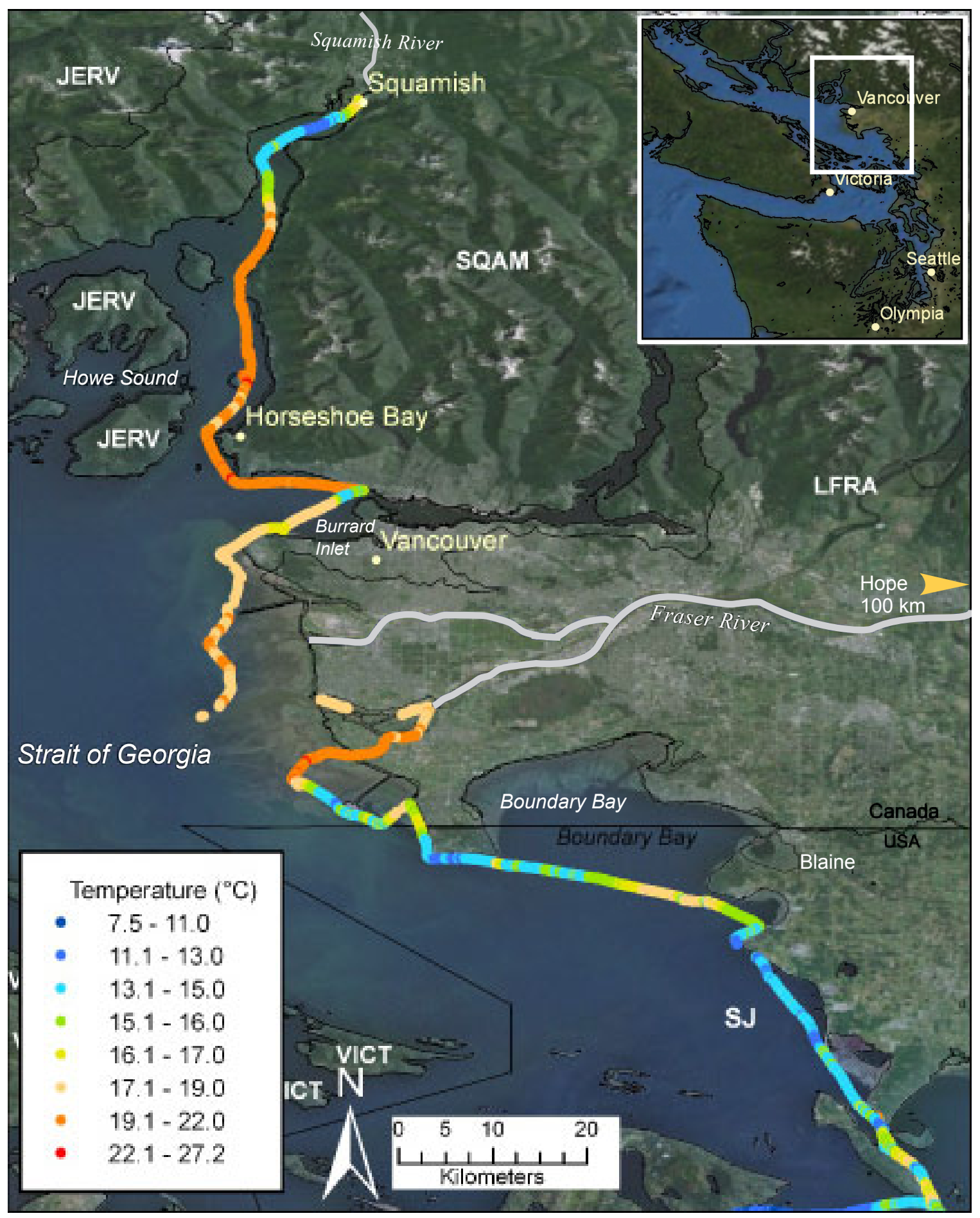

Figure 6. Surface-water temperatures recorded in degrees Celsius in the northern portion of the Salish Sea from July 22 to 24, 2009. This region includes data from Squamish and Lower Fraser Basins and the Fraser River. 


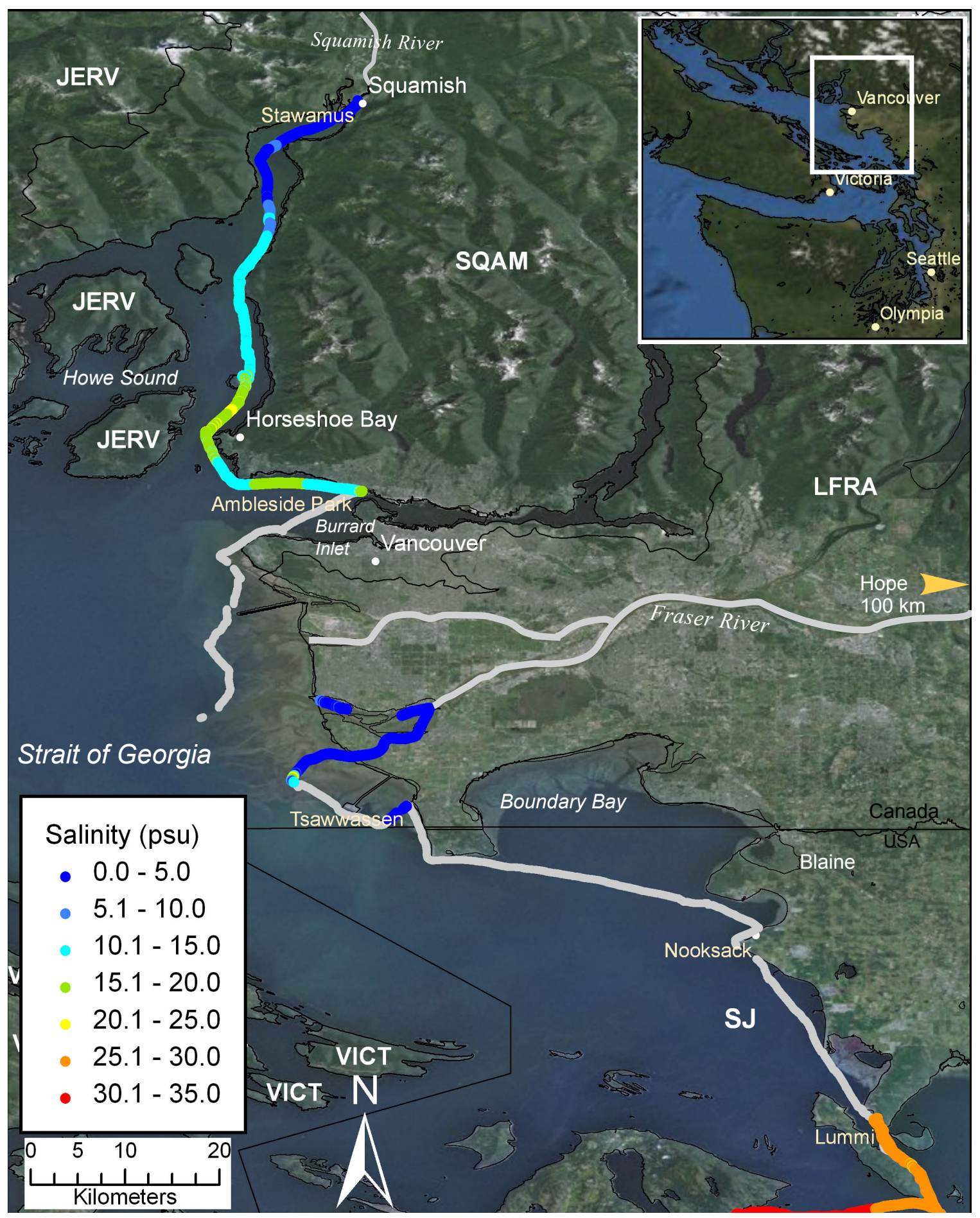

Figure 7. Surface-water salinity results recorded in practical salinity units in the northern portion of the Salish Sea from July 22 to 24, 2009. This region includes data from Squamish and Lower Fraser Basins and the Fraser River. 


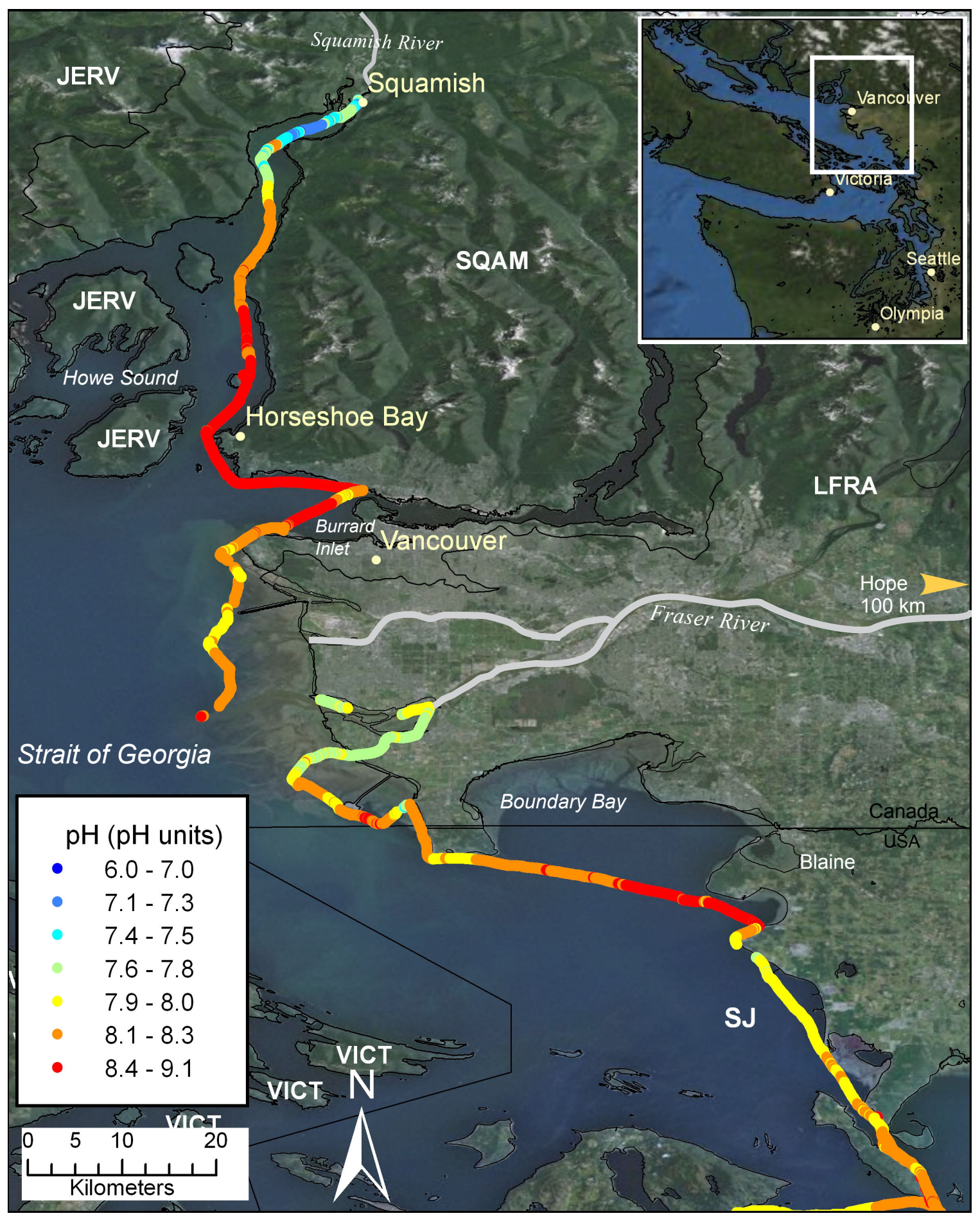

Figure 8. Surface-water $\mathrm{pH}$ recorded in standard units in the northern portion of the Salish Sea from July 22 to 24 , 2009. This region includes data from Squamish and Lower Fraser Basins and the Fraser River. 


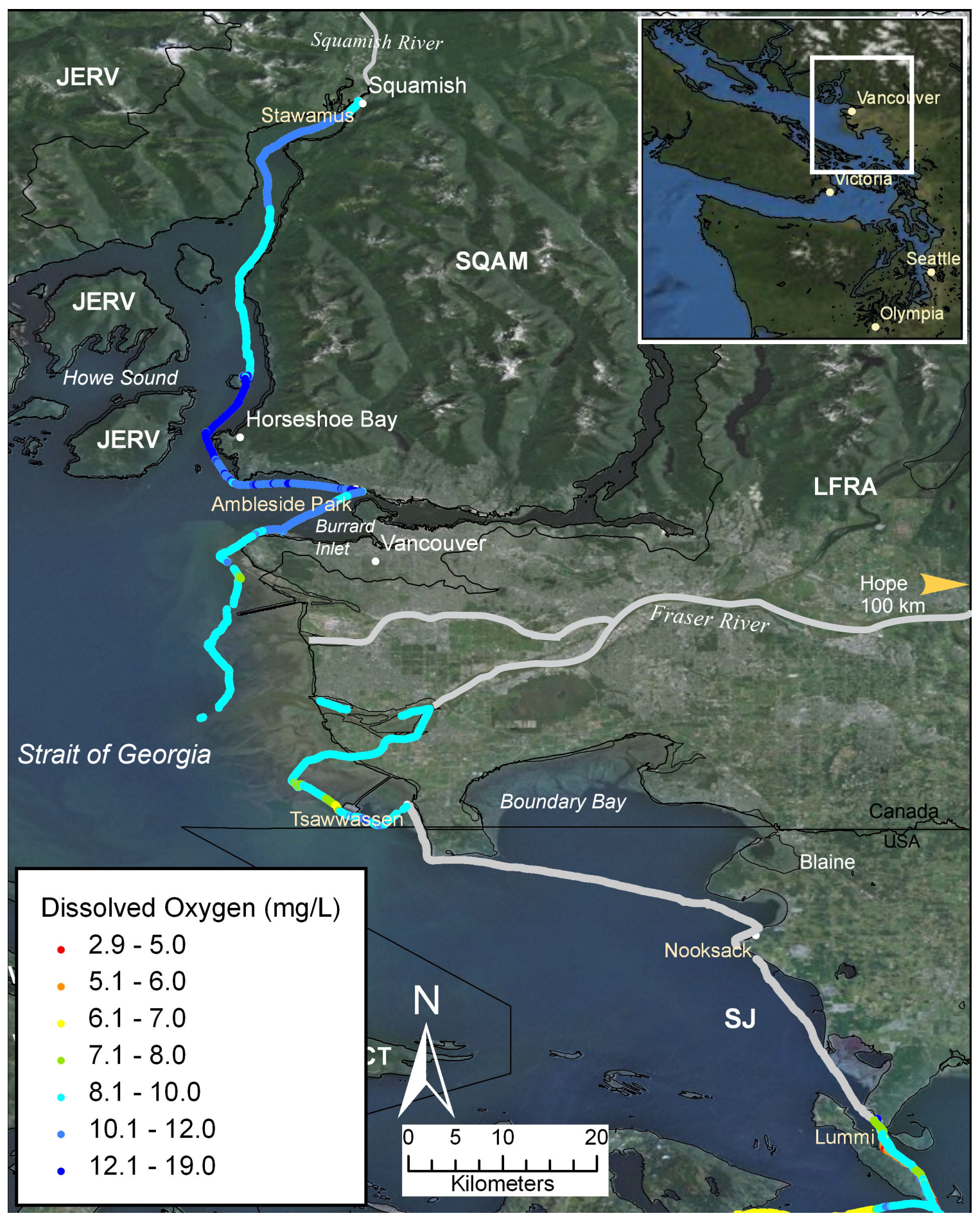

Figure 9. Surface-water dissolved oxygen recorded in milligrams per liter in the northern portion of the Salish Sea from July 22 to 24, 2009. This region includes data from Squamish and Lower Fraser Basins and the Fraser River. 


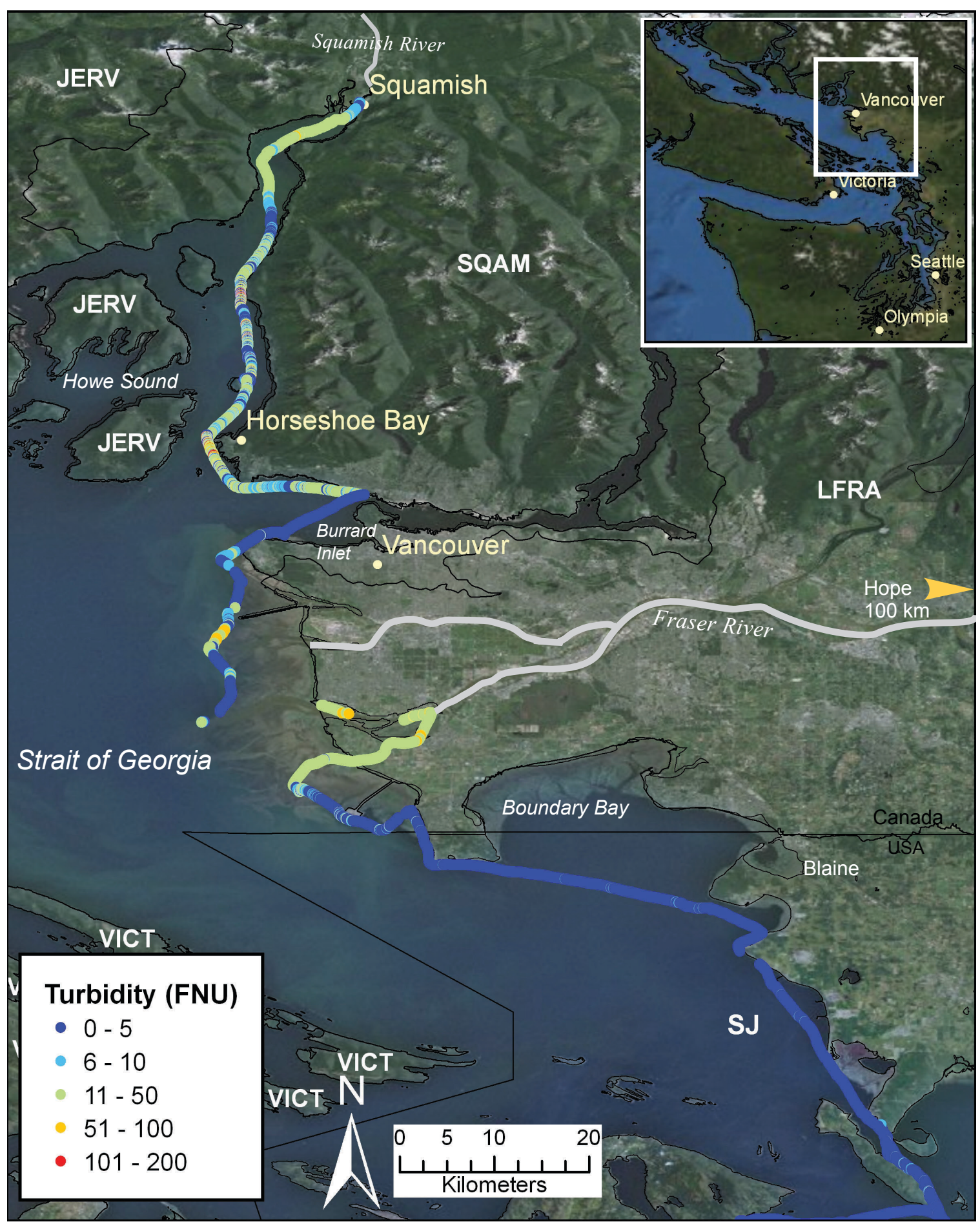

Figure 10.Surface-water turbidity recorded in Formazin Nephelometric Units in the northern Salish Sea from July 22 to 24, 2009. This region includes data from Squamish and Lower Fraser Basins and the Fraser River. 
Table 6. Water-quality statistics from Squamish and Lower Fraser Basins, 2009.

[Average, median, maximum, minimum, standard deviation (StdDev), and number of observations (n) for temperature in degrees Celsius, salinity in pratical salinity units, $\mathrm{pH}$ in $\mathrm{pH}$ units, dissolved-oxygen in milligrams per liter and percent saturation, and turbidity in Formazin Nephelometric Units. NaN was used for parameters which did not meet data-quality standards.]

\begin{tabular}{|c|c|c|c|}
\hline 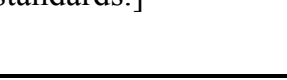 & \multicolumn{3}{|c|}{ Squamish } \\
\hline$n$ & 4,057 & 889 & 4,946 \\
\hline $\begin{array}{l}\text { Temperature in } \\
\text { degrees Celsius }\end{array}$ & $7 / 22 / 2009$ & $7 / 23 / 2009$ & $\begin{array}{c}\text { All } \\
\text { Days }\end{array}$ \\
\hline Average & 18.6 & 17.4 & 18.4 \\
\hline Maximum & 22.4 & 18.9 & 22.4 \\
\hline Minimum & 12.0 & 12.6 & 12.0 \\
\hline StdDev & 2.8 & 1.3 & 2.6 \\
\hline $\begin{array}{l}\text { Salinity in practical } \\
\text { salinity units }\end{array}$ & $7 / 22 / 2009$ & $7 / 23 / 2009$ & $\begin{array}{c}\text { All } \\
\text { Days }\end{array}$ \\
\hline Average & 11 & $\mathrm{NaN}$ & 11 \\
\hline Maximum & 27 & $\mathrm{NaN}$ & 27 \\
\hline Minimum & 0.5 & $\mathrm{NaN}$ & 0.5 \\
\hline StdDev & 5.5 & $\mathrm{NaN}$ & 5.5 \\
\hline $\mathrm{pH}$ in $\mathrm{pH}$ units & $7 / 22 / 2009$ & $7 / 23 / 2009$ & $\begin{array}{c}\text { All } \\
\text { Days }\end{array}$ \\
\hline Maximum & 9.1 & 8.5 & 9.1 \\
\hline Minimum & 6.8 & 7.9 & 6.8 \\
\hline Median & 8.3 & 8.2 & 8.3 \\
\hline $\begin{array}{l}\text { Dissolved Oxygen in } \\
\text { milligrams per liter }\end{array}$ & $7 / 22 / 2009$ & $7 / 23 / 2009$ & $\begin{array}{c}\text { All } \\
\text { Days }\end{array}$ \\
\hline Average & 11.0 & 9.9 & 10.8 \\
\hline Maximum & 16.9 & 11.6 & 16.9 \\
\hline Minimum & 8.6 & 7.9 & 7.9 \\
\hline StdDev & 1.9 & 1.1 & 1.8 \\
\hline $\begin{array}{l}\text { Dissolved Oxygen } \\
\text { percent saturation }\end{array}$ & $7 / 22 / 2009$ & $7 / 23 / 2009$ & $\begin{array}{c}\text { All } \\
\text { Days }\end{array}$ \\
\hline Average & 126.0 & 116.2 & 124.2 \\
\hline Maximum & 208.3 & 138.7 & 208.3 \\
\hline Minimum & 95.7 & 93.6 & 93.6 \\
\hline StdDev & 27.2 & 14.5 & 25.7 \\
\hline $\begin{array}{l}\text { Turbidity in Formazin } \\
\text { Nephelometric Units }\end{array}$ & $7 / 22 / 2009$ & $7 / 23 / 2009$ & $\begin{array}{c}\text { All } \\
\text { Days } \\
\end{array}$ \\
\hline Average & 16 & 2 & 13 \\
\hline Maximum & 176 & 39 & 176 \\
\hline Minimum & 0.0 & 0.0 & 0.0 \\
\hline StdDev & 18 & 4 & 17 \\
\hline
\end{tabular}

\begin{tabular}{|c|c|c|c|}
\hline \multicolumn{4}{|c|}{ Lower Fraser } \\
\hline 981 & 846 & 141 & 1,968 \\
\hline $7 / 23 / 2009$ & $7 / 24 / 2009$ & $7 / 25 / 2009$ & $\begin{array}{c}\text { All } \\
\text { Days }\end{array}$ \\
\hline 18.7 & 16.3 & 15.9 & 17.5 \\
\hline 19.7 & 23.5 & 16.6 & 23.5 \\
\hline 17.2 & 12.2 & 15.4 & 12.2 \\
\hline 0.4 & 2.4 & 0.3 & 2.0 \\
\hline $7 / 23 / 2009$ & $7 / 24 / 2009$ & $7 / 25 / 2009$ & $\begin{array}{c}\text { All } \\
\text { Days }\end{array}$ \\
\hline $\mathrm{NaN}$ & 3.9 & $\mathrm{NaN}$ & 3.9 \\
\hline $\mathrm{NaN}$ & 23 & $\mathrm{NaN}$ & 23 \\
\hline $\mathrm{NaN}$ & 0.0 & $\mathrm{NaN}$ & 0.0 \\
\hline $\mathrm{NaN}$ & 6.2 & $\mathrm{NaN}$ & 6.2 \\
\hline $7 / 23 / 2009$ & $7 / 24 / 2009$ & $7 / 25 / 2009$ & $\begin{array}{c}\text { All } \\
\text { Days }\end{array}$ \\
\hline 8.3 & 8.5 & 8.3 & 8.5 \\
\hline 7.9 & 7.5 & 8.1 & 7.5 \\
\hline 8.1 & 8.0 & 8.2 & 8.1 \\
\hline $7 / 23 / 2009$ & $7 / 24 / 2009$ & $7 / 25 / 2009$ & $\begin{array}{c}\text { All } \\
\text { Days } \\
\end{array}$ \\
\hline 8.7 & 8.8 & $\mathrm{NaN}$ & 8.7 \\
\hline 9.9 & 13.8 & $\mathrm{NaN}$ & 13.8 \\
\hline 7.8 & 6.3 & $\mathrm{NaN}$ & 6.3 \\
\hline 0.4 & 1.2 & $\mathrm{NaN}$ & 0.9 \\
\hline $7 / 23 / 2009$ & $7 / 24 / 2009$ & $7 / 25 / 2009$ & $\begin{array}{c}\text { All } \\
\text { Days }\end{array}$ \\
\hline 102.4 & 116.1 & $\mathrm{NaN}$ & 108.7 \\
\hline 112.8 & 181.6 & $\mathrm{NaN}$ & 181.6 \\
\hline 92.8 & 85.2 & $\mathrm{NaN}$ & 85.2 \\
\hline 5.2 & 20.1 & $\mathrm{NaN}$ & 15.7 \\
\hline $7 / 23 / 2009$ & $7 / 24 / 2009$ & $7 / 25 / 2009$ & $\begin{array}{c}\text { All } \\
\text { Days }\end{array}$ \\
\hline 11 & 6 & 0 & 8 \\
\hline 91 & 87 & 11 & 91 \\
\hline 0.0 & 0.0 & 0.0 & 0.0 \\
\hline 21 & 10 & 1 & 16 \\
\hline
\end{tabular}


Table 7. Water-quality statistics from Fraser River, 2009.

[Average, median, maximum, minimum, standard deviation (StdDev), and number of observations (n) for temperature in degrees Celsius, salinity in pratical salinity units, $\mathrm{pH}$ in $\mathrm{pH}$ units, dissolved-oxygen in milligrams per liter and percent saturation, and turbidity in Formazin Nephelometric Units.]

\begin{tabular}{|l|c|l|l|}
\hline \multicolumn{4}{|c|}{ Fraser River } \\
\hline $\mathrm{n}$ & 914 & $\mathrm{n}$ & 914 \\
\hline
\end{tabular}

\begin{tabular}{|l|c|}
\hline $\begin{array}{l}\text { Temperature in } \\
\text { degrees Celsius }\end{array}$ & $7 / 24 / 2009$ \\
\hline \hline Average & 19.2 \\
\hline Maximum & 26.4 \\
\hline Minimum & 18.3 \\
\hline StdDev & 1.0 \\
\hline
\end{tabular}

\begin{tabular}{|l|c|}
\hline $\begin{array}{l}\text { Dissolved Oxygen } \\
\text { in milligrams per } \\
\text { liter }\end{array}$ & $7 / 24 / 2009$ \\
\hline \hline Average & 9.1 \\
\hline Maximum & 10.0 \\
\hline Minimum & 8.6 \\
\hline StdDev & 0.1 \\
\hline
\end{tabular}

\begin{tabular}{|l|c|}
\hline $\begin{array}{l}\text { Salinity in } \\
\text { practical salinity } \\
\text { units }\end{array}$ & $7 / 24 / 2009$ \\
\hline \hline Average & 1.0 \\
\hline Maximum & 5.8 \\
\hline Minimum & 0.1 \\
\hline StdDev & 1.6 \\
\hline
\end{tabular}

\begin{tabular}{|l|c|}
\hline $\begin{array}{l}\text { Dissolved Oxygen } \\
\text { percent saturation }\end{array}$ & $7 / 24 / 2009$ \\
\hline \hline Average & 98.7 \\
\hline Maximum & 124.5 \\
\hline Minimum & 96.3 \\
\hline StdDev & 1.9 \\
\hline
\end{tabular}

\begin{tabular}{|l|c|}
\hline & \\
$\mathrm{pH}$ in $\mathrm{pH}$ units & $7 / 24 / 2009$ \\
\hline \hline Maximum & 8.4 \\
\hline Minimum & 7.7 \\
\hline Median & 7.8 \\
\hline
\end{tabular}

\begin{tabular}{|l|c|}
\hline Turbidity in & \\
Formazin & \\
Nephelometric & \\
Units & $7 / 24 / 2009$ \\
\hline \hline Average & 28 \\
\hline Maximum & 89 \\
\hline Minimum & 3.9 \\
\hline StdDev & 14 \\
\hline
\end{tabular}

\section{Central Salish Sea}

The Central Salish Sea region includes the San Juan (SJ), Whidbey (WB), and North Central Puget Sound (NC) Basins and the Skagit River. The San Juan and North Central Basins are mixing zones where water-quality parameters are influenced significantly by water from the Strait of Juan de Fuca and by waters circulating through the Georgia Strait (San Juan Basin) and Puget Sound-Hood Canal (North Central Basin). San Juan Basin (table 8) was monitored by the TJWQP for seven days (from July 22 to July 29), with a rest day and no monitoring on July 28. Whidbey Basin (table 9) was monitored six days (from July 21 to August 4). North Central Basin was monitored on August 3 (table 10), and the Skagit River was monitored August 1 and 2 (table 10). Air temperatures recorded in Blaine, Wash. for the month of July averaged $18{ }^{\circ} \mathrm{C}$, with a high of $30^{\circ} \mathrm{C}$, which occurred during the sampling period (National Oceanic and Atmospheric Administration, 2009) and had the lowest maximum temperature for July in the Salish Sea region. Central Salish Sea results for temperature, salinity, pH, dissolved oxygen, and turbidity are shown in figures 12-16. The San Juan Basin surface-water temperatures ranged from a minimum of $10.7^{\circ} \mathrm{C}$ to a maximum of $22.5^{\circ} \mathrm{C}$, and averaged $13.6^{\circ} \mathrm{C}(\mathrm{n}=18,212)$ (table 7). The warmest areas were along the eastern shoreline of the basin, particularly Samish Bay and the Swinomish Channel, Bellingham Bay off of Lummi Island, and offshore of Blaine, Wash.. The salinity 
ranged from 2.5 to $32 \mathrm{psu}$, and averaged $29 \mathrm{psu}(\mathrm{n}=12,260)$. The median $\mathrm{pH}$ for San Juan Basin was 7.9 $\mathrm{pH}$ units $(\mathrm{n}=18,212)$, with a maximum of 8.9 and a minimum of $6.0 \mathrm{pH}$ units. Dissolved-oxygen concentrations ranged from 4.2 to $16.3 \mathrm{mg} / \mathrm{L}$ with an average of $7.9 \mathrm{mg} / \mathrm{L}(\mathrm{n}=10,235)$. Dissolved oxygen saturation ranged from 57.0 to 204 percent. Turbidity had a minimum of 0.0 and a maximum of $95 \mathrm{FNU}$ and averaged $1 \mathrm{FNU}(\mathrm{n}=18,212)$.

Surface-water temperatures (table 9) for Whidbey Basin ranged from 11.2 to $21.8^{\circ} \mathrm{C}$ and averaged $16.8^{\circ} \mathrm{C}(\mathrm{n}=7,962)$. The coolest temperatures were recorded from Deception Pass across to Hope Island, and the warmest temperatures were recorded in south Whidbey Basin near the outlet of East Basin. The salinity ranged from 16 to $30 \mathrm{psu}$, and averaged $25 \mathrm{psu}(\mathrm{n}=5,915)$, with depressed salinity levels in the Swinomish Channel and off shore of the Tulalip Reservation, likely because of dilution from the Skagit and Snohomish Rivers, respectively. The $\mathrm{pH}$ ranged from 7.5 to $8.4 \mathrm{pH}$ units with a median of $8.2 \mathrm{pH}$ units $(\mathrm{n}=7,962)$. The dissolved-oxygen concentration ranged from 4.0 to $12.6 \mathrm{mg} / \mathrm{L}$ and averaged 8.4 $\mathrm{mg} / \mathrm{L}(\mathrm{n}=5,465)$. Dissolved-oxygen saturation ranged from 48.1 to 146.7 percent. Turbidity ranged from 0.0 to $110 \mathrm{FNU}$, and averaged $3 \mathrm{FNU}(\mathrm{n}=7,962)$.

North Central Basin surface-water temperatures (table 10) had a minimum of 12.3 and a maximum of $15.5^{\circ} \mathrm{C}$ and averaged $13.9^{\circ} \mathrm{C}(\mathrm{n}=1,104)$. Salinity ranged from 21 to $30 \mathrm{psu}$, and averaged $29 \mathrm{psu}$. The median $\mathrm{pH}$ was 8.1 units, and it ranged from 8.3 to $7.9 \mathrm{pH}$ units. Dissolved-oxygen concentration had a minimum of 5.9 and a maximum of $9.4 \mathrm{mg} / \mathrm{L}$ and averaged $7.1 \mathrm{mg} / \mathrm{L}$. Dissolved-oxygen saturation ranged from 107.9 to 69.7 percent. Turbidity results are not available for the North Central Basin due to instrument malfunctions.

The Skagit River is the largest freshwater input into the Salish Sea south of the Fraser River. The average discharge of the Skagit River at Mt. Vernon, Wash. (Station 12200500) as the canoes traveled through the region on August 1 and 2 was $322 \mathrm{~m}^{3} / \mathrm{s}$ (11,371 cfs) (fig. 11), approaching base-flow levels (U.S. Geological Survey, 2009). The surface-water temperatures (table 10) had a minimum of $15.5^{\circ} \mathrm{C}$ and a maximum of $23.8^{\circ} \mathrm{C}$ at the delta and the average temperature recorded during TJWQP monitoring was $16.8{ }^{\circ} \mathrm{C}(\mathrm{n}=2,367)$. Salinity ranged from 0.0 to $6.0 \mathrm{psu}$, and averaged $0.1 \mathrm{psu}$. The median $\mathrm{pH}$ of the Skagit River was $7.4 \mathrm{pH}$ units, with a minimum of 6.6 and a maximum of $8.8 \mathrm{pH}$ units. Dissolved oxygen concentrations ranged from 7.5 to $18.7 \mathrm{mg} / \mathrm{L}$, and averaged $9.7 \mathrm{mg} / \mathrm{L}(\mathrm{n}=2,367)$. Dissolved oxygen saturation ranged from 77.9 to 187.3 percent. Turbidity ranged from 10 to $29 \mathrm{FNU}$ and averaged $22 \mathrm{FNU}(\mathrm{n}=587)$. 


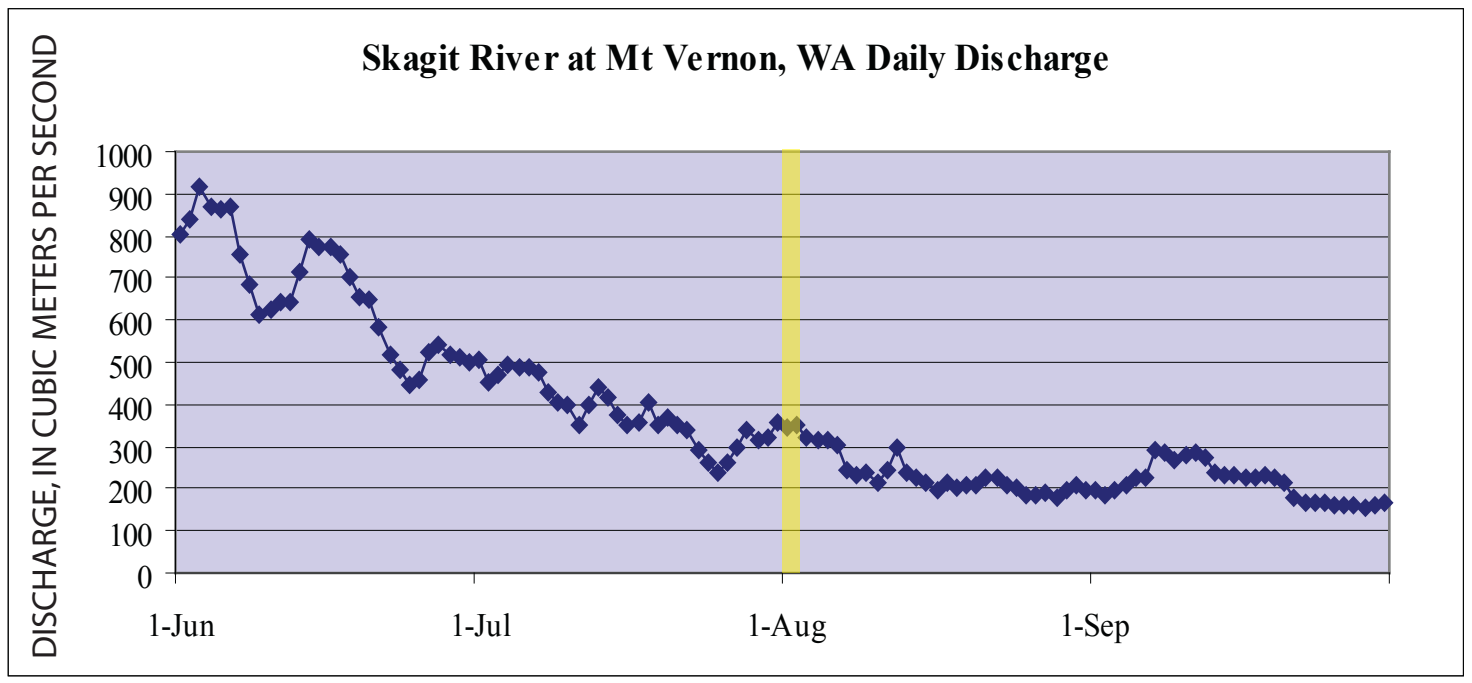

Figure 11. Daily river discharge in cubic meters per second for the Skagit River at Mt. Vernon, Wash. (Station 12200500). The yellow box indicates the time period that the canoes pulled past the Skagit delta. Data collected by the U.S. Geological Survey. 


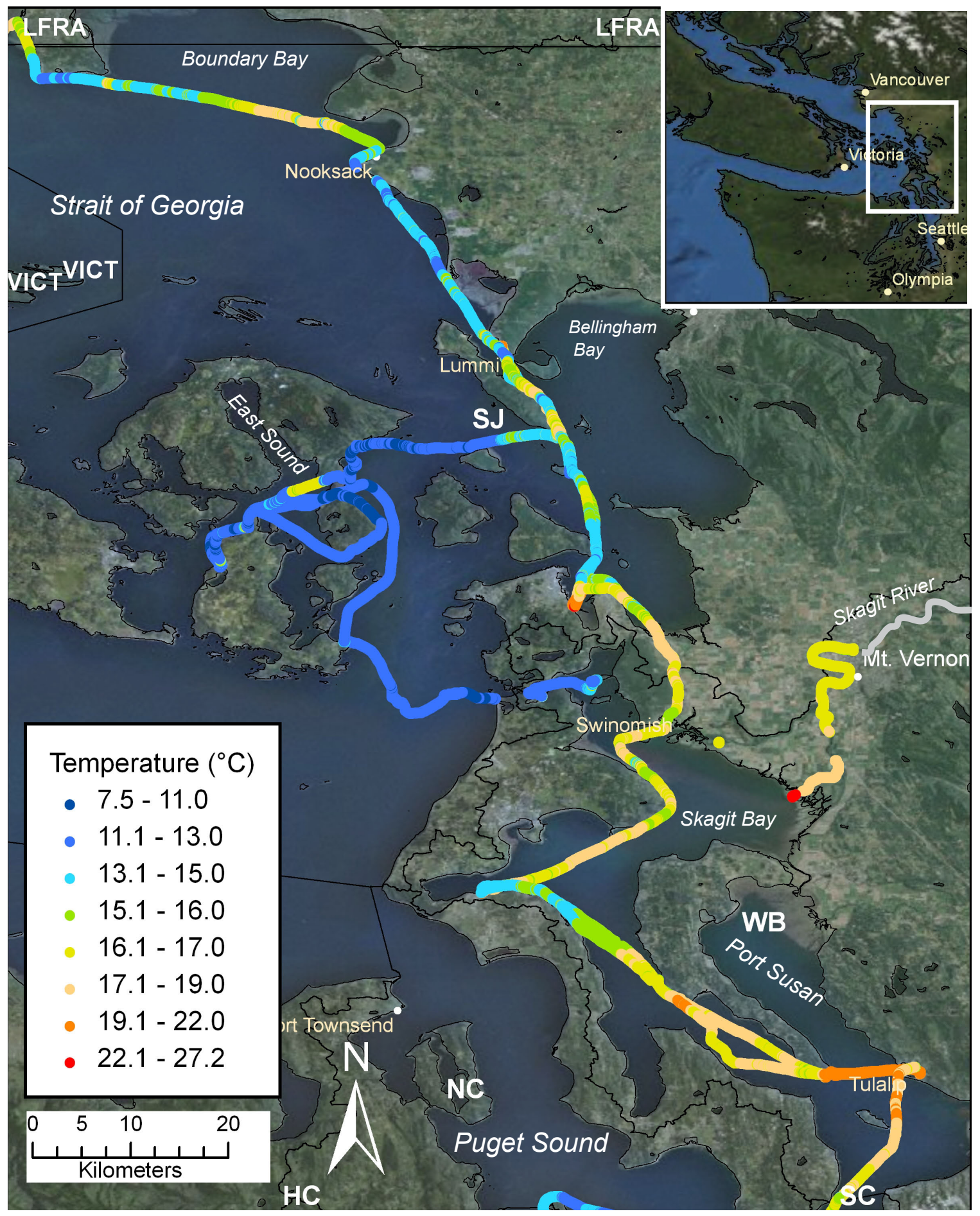

Figure 12. Surface-water temperature recorded in degrees Celsius in the central Salish Sea from July 21 to August 4 , 2009. This region includes results from the San Juan, Whidbey, and North Central Puget Sound and from the Skagit River. 


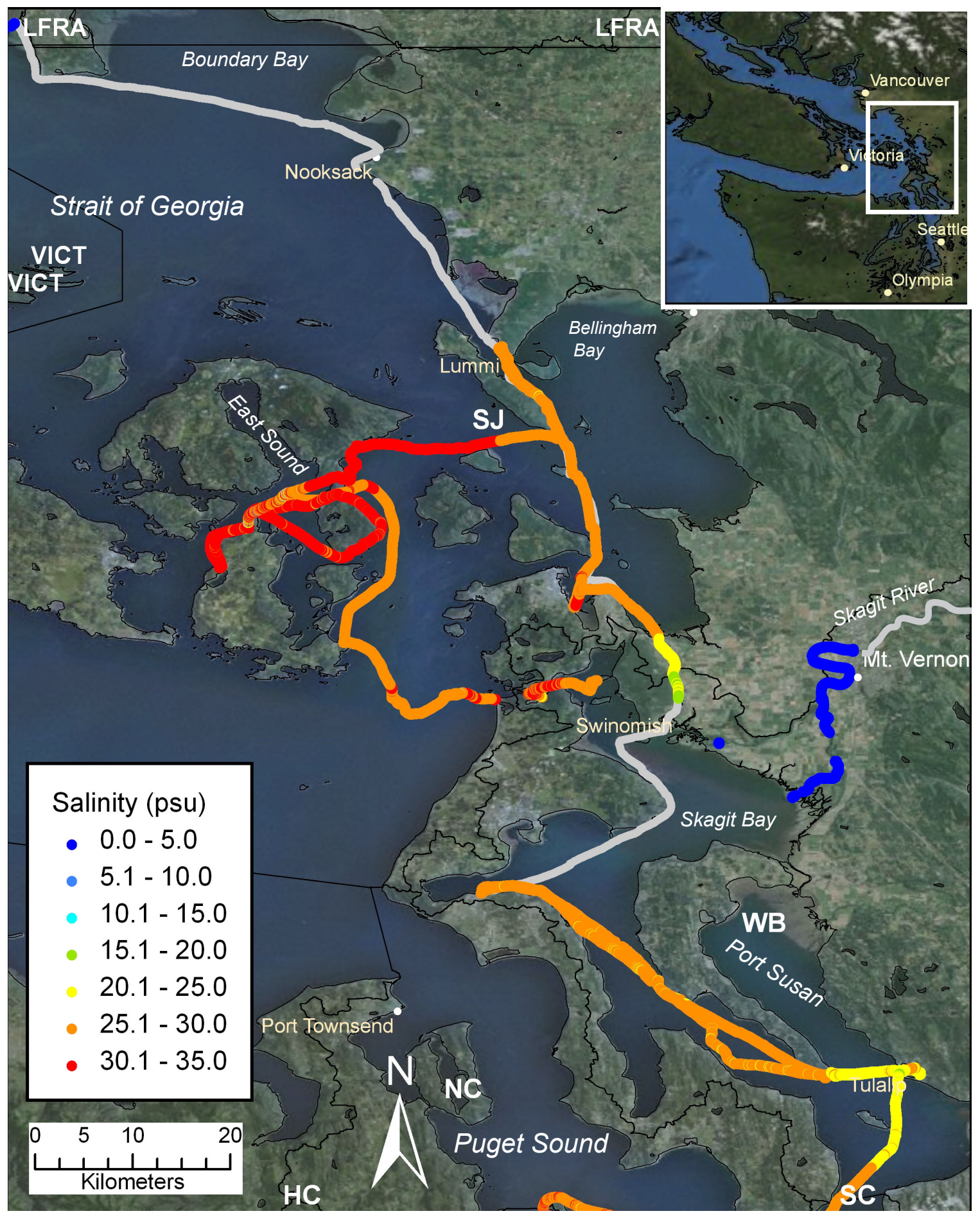

Figure 13. Surface-water salinity recorded in practical salinity units in the central Salish Sea from July 21 to August 4 , 2009. This region includes results from the San Juan, Whidbey, and North Central Puget Sound and from the Skagit River. 


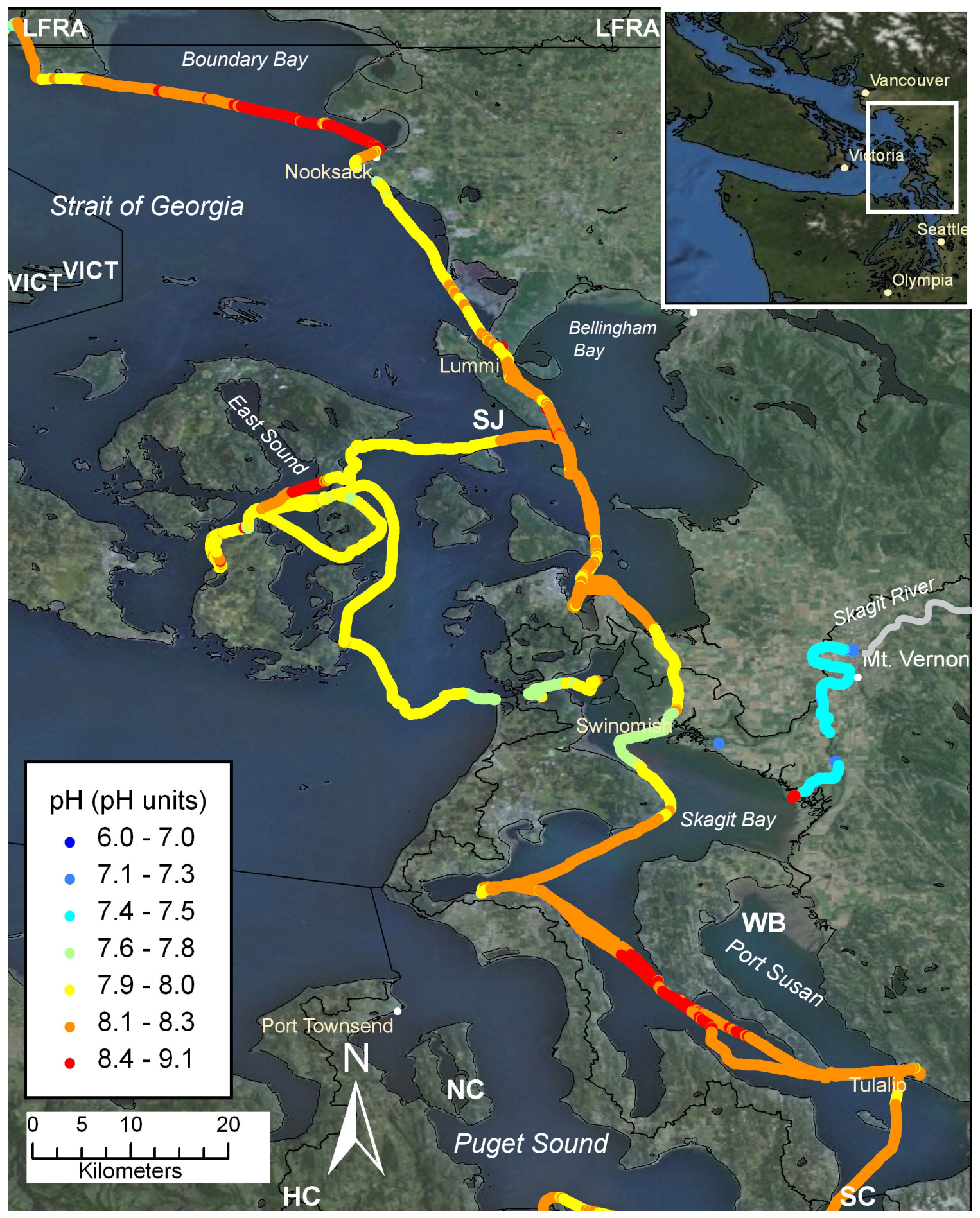

Figure 14. Surface-water pH recorded in standard units in the central Salish Sea from July 21 to August 4, 2009. This region includes results from the San Juan, Whidbey, and North Central Puget Sound and from the Skagit River. 


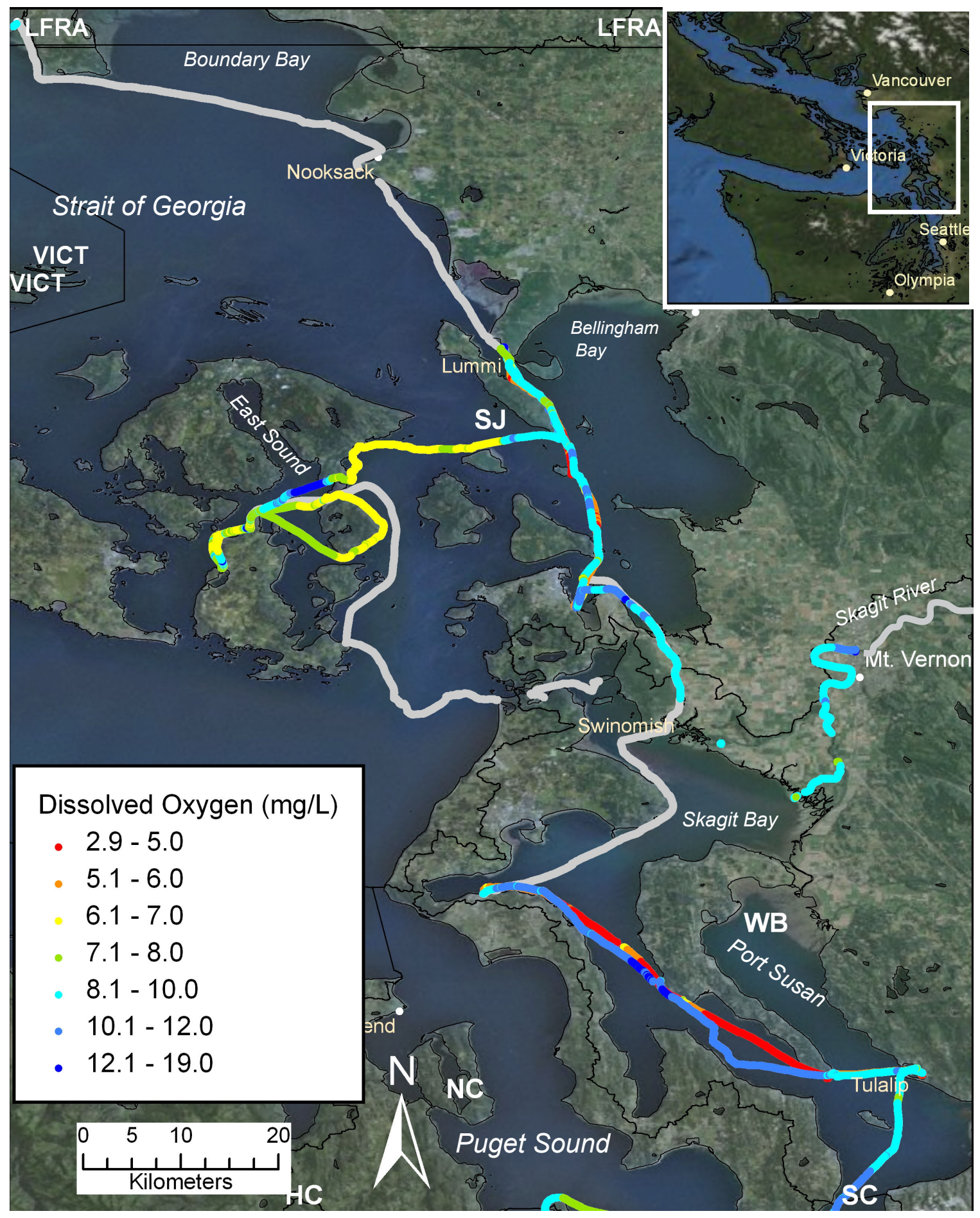

Figure 15. Surface-water dissolved oxygen recorded in milligrams per liter in the central Salish Sea from July 21 to August 4, 2009. This region includes results from the San Juan, Whidbey, and North Central Puget Sound and from the Skagit River. 


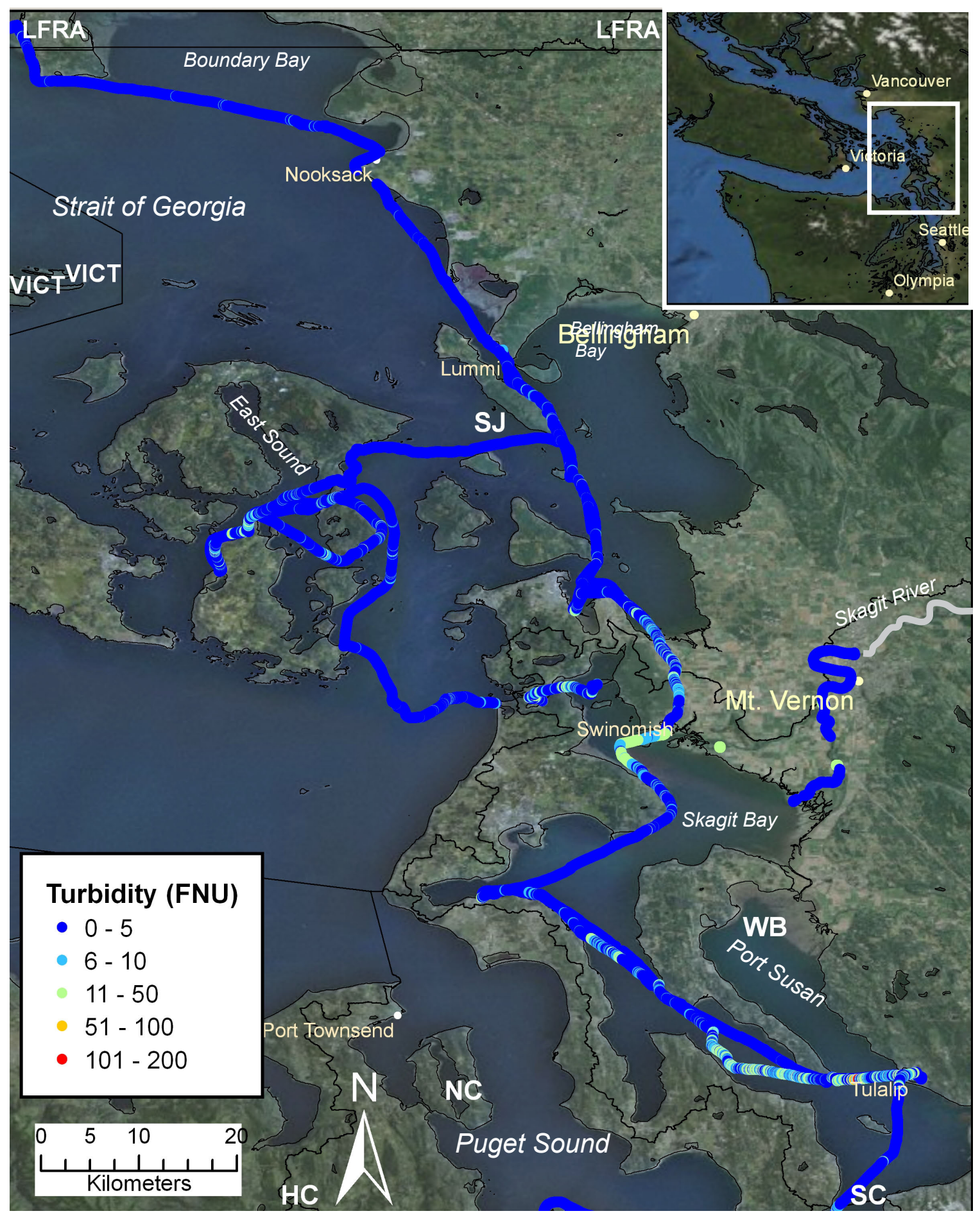

Figure 16. Surface-water turbidity recorded in Formazin Nephelometric Units along the central Salish Sea from July 21 to August 4, 2009. This region includes results from the San Juan, Whidbey, and North Central Puget Sound and from the Skagit River. 
Table 8. Water-quality statistics for San Juan Basin, 2009.

[Average, median, maximum, minimum, standard deviation (StdDev), and number of observations (n) for temperature in degrees Celsius, salinity in pratical salinity units, $\mathrm{pH}$ in $\mathrm{pH}$ units, dissolved-oxygen in milligrams per liter and percent saturation, and turbidity in Formazin Nephelometric Units. NaN was used for parameters which did not meet data-quality standards.]

\begin{tabular}{|l|c|c|c|c|c|c|c|c|c|c|}
\hline \multicolumn{7}{|c|}{ San Juan } \\
\hline \hline $\mathrm{n}$ & 3,702 & 1,082 & 1,933 & 2,141 & 3,992 & 3,604 & 1,758 & 18,212 \\
\hline $\begin{array}{l}\text { Temperature in } \\
\text { degrees Celsius }\end{array}$ & $7 / 22 / 09$ & $7 / 23 / 09$ & $7 / 24 / 09$ & $7 / 25 / 09$ & $7 / 26 / 09$ & $7 / 28 / 09$ & $7 / 29 / 09$ & $\begin{array}{c}\text { All } \\
\text { Days }\end{array}$ \\
\hline \hline Average & 11.7 & 11.7 & 11.4 & 15.0 & 13.6 & 15.1 & 17.0 & 13.6 \\
\hline Maximum & 14.3 & 18.0 & 13.4 & 18.8 & 20.0 & 22.5 & 20.5 & 22.5 \\
\hline Minimum & 10.7 & 10.8 & 10.7 & 11.8 & 10.7 & 11.8 & 13.8 & 10.7 \\
\hline StdDev & 0.4 & 1.2 & 0.5 & 1.5 & 2.2 & 2.0 & 1.1 & 2.4 \\
\hline \begin{tabular}{|l|c|c|c|c|c|c|c|c|c|}
\hline Salinity in practical \\
salinity units
\end{tabular} & $7 / 22 / 09$ & $7 / 23 / 09$ & $7 / 24 / 09$ & $7 / 25 / 09$ & $7 / 26 / 09$ & $7 / 28 / 09$ & $7 / 29 / 09$ & $\begin{array}{c}\text { All } \\
\text { Days }\end{array}$ \\
\hline \hline Average & 30 & 30 & 30 & NaN & 29 & 29 & 27 & 29 \\
\hline Maximum & 32 & 31 & 31 & NaN & 31 & 31 & 31 & 32 \\
\hline Minimum & 12 & 27 & 21 & NaN & 2.5 & 20 & 20 & 2.5 \\
\hline StdDev & 0.5 & 0.3 & 0.4 & NaN & 2.0 & 1.1 & 3.4 & 1.7 \\
\hline pH in pH units & $7 / 22 / 09$ & $7 / 23 / 09$ & $7 / 24 / 09$ & $7 / 25 / 09$ & $7 / 26 / 09$ & $7 / 28 / 09$ & $7 / 29 / 09$ & $\begin{array}{c}\text { All } \\
\text { Days }\end{array}$ \\
\hline \hline Maximum & 8.2 & 8.7 & 8.1 & 8.9 & 8.7 & 8.3 & 8.3 & 8.9 \\
\hline Minimum & 6.0 & 7.8 & 7.8 & 7.8 & 7.6 & 7.8 & 7.8 & 6.0 \\
\hline Median & 7.9 & 7.9 & 7.9 & 8.2 & 7.9 & 8.1 & 8.1 & 7.9 \\
\hline
\end{tabular}

\begin{tabular}{|l|c|c|c|c|c|c|c|c|}
\hline $\begin{array}{l}\text { Dissolved Oxygen } \\
\text { in milligrams per } \\
\text { liter }\end{array}$ & $7 / 22 / 09$ & $7 / 23 / 09$ & $7 / 24 / 09$ & $7 / 25 / 09$ & $7 / 26 / 09$ & $7 / 28 / 09$ & $7 / 29 / 09$ & $\begin{array}{c}\text { All } \\
\text { Days }\end{array}$ \\
\hline \hline Average & $\mathrm{NaN}$ & 7.9 & 7.0 & $\mathrm{NaN}$ & 8.6 & 7.4 & 9.6 & 7.9 \\
\hline Maximum & $\mathrm{NaN}$ & 15.8 & 9.6 & $\mathrm{NaN}$ & 16.3 & 12.5 & 12.9 & 16.3 \\
\hline Minimum & $\mathrm{NaN}$ & 6.5 & 6.1 & $\mathrm{NaN}$ & 6.2 & 4.2 & 7.8 & 4.2 \\
\hline StdDev & $\mathrm{NaN}$ & 1.6 & 0.5 & $\mathrm{NaN}$ & 2.0 & 2.0 & 0.8 & 1.9 \\
\hline $\begin{array}{l}\text { Dissolved Oxygen } \\
\text { percent saturation }\end{array}$ & $7 / 22 / 09$ & $7 / 23 / 09$ & $7 / 24 / 09$ & $7 / 25 / 09$ & $7 / 26 / 09$ & $7 / 28 / 09$ & $7 / 29 / 09$ & $\begin{array}{c}\text { All } \\
\text { Days }\end{array}$ \\
\hline \hline Average & $\mathrm{NaN}$ & 89.0 & 77.8 & $\mathrm{NaN}$ & 99.5 & 93.7 & 117.5 & 93.6 \\
\hline Maximum & $\mathrm{NaN}$ & 194.2 & 109.0 & $\mathrm{NaN}$ & 204.7 & 162.7 & 159.4 & 204.7 \\
\hline Minimum & $\mathrm{NaN}$ & 71.2 & 66.8 & $\mathrm{NaN}$ & 68.9 & 57.0 & 95.4 & 57.0 \\
\hline StdDev & $\mathrm{NaN}$ & 20.7 & 6.7 & $\mathrm{NaN}$ & 27.9 & 20.5 & 10.7 & 23.0 \\
\hline
\end{tabular}

\begin{tabular}{|l|c|c|c|c|c|c|c|c|}
\hline $\begin{array}{l}\text { Turbidity in } \\
\text { Formazin } \\
\text { Nephelometric Units }\end{array}$ & $7 / 22 / 09$ & $7 / 23 / 09$ & $7 / 24 / 09$ & $7 / 25 / 09$ & $7 / 26 / 09$ & $7 / 28 / 09$ & $7 / 29 / 09$ & $\begin{array}{c}\text { All } \\
\text { Days }\end{array}$ \\
\hline \hline Average & 2 & 4 & 2 & 0 & 1 & 1 & 3 & 1 \\
\hline Maximum & 50 & 95 & 23 & 10 & 23 & 24 & 61 & 95 \\
\hline Minimum & 0.0 & 0.0 & 0.0 & 0.0 & 0.0 & 0.0 & 0.0 & 0.0 \\
\hline StdDev & 2 & 7 & 2 & 1 & 2 & 2 & 4 & 3 \\
\hline
\end{tabular}


Table 9. Water-quality statistics for Whidbey Basin, 2009.

[Average, median, maximum, minimum, standard deviation (StdDev), and number of observations (n) for temperature in degrees Celsius, salinity in pratical salinity units, $\mathrm{pH}$ in $\mathrm{pH}$ units, dissolved-oxygen in milligrams per liter and percent saturation, and turbidity in Formazin Nephelometric Units. NaN was used for parameters which did not meet data-quality standards.]

\begin{tabular}{|l|l|l|l|l|l|l|l|}
\hline \multicolumn{1}{|c|}{ Whidbey Basin } \\
\hline \hline $\mathrm{n}$ & 450 & 444 & 1,805 & 4,300 & 949 & 14 & 7,962 \\
\hline
\end{tabular}

\begin{tabular}{|l|c|c|c|c|c|c|c|}
\hline $\begin{array}{l}\text { Temperature in } \\
\text { degrees Celsius }\end{array}$ & $7 / 21 / 2009$ & $7 / 29 / 2009$ & $7 / 30 / 2009$ & $7 / 31 / 2009$ & $8 / 2 / 2009$ & $8 / 4 / 2009$ & $\begin{array}{c}\text { All } \\
\text { Days }\end{array}$ \\
\hline \hline Average & 12.0 & 16.9 & 16.8 & 17.1 & 17.7 & 16.0 & 16.8 \\
\hline Maximum & 18.4 & 19.3 & 19.3 & 21.8 & 19.9 & 16.1 & 21.8 \\
\hline Minimum & 11.2 & 15.8 & 12.4 & 11.7 & 14.3 & 15.4 & 11.2 \\
\hline StdDev & 1.2 & 0.5 & 0.8 & 2.2 & 1.2 & 0.2 & 2.1 \\
\hline
\end{tabular}

\begin{tabular}{|l|c|c|c|c|c|c|c|}
\hline $\begin{array}{l}\text { Salinity in practical } \\
\text { salinity units }\end{array}$ & $7 / 21 / 2009$ & $7 / 29 / 2009$ & $7 / 30 / 2009$ & $7 / 31 / 2009$ & $8 / 2 / 2009$ & $8 / 4 / 2009$ & $\begin{array}{c}\text { All } \\
\text { Days }\end{array}$ \\
\hline \hline Average & 29 & 20 & $\mathrm{NaN}$ & 26 & 24 & 28 & 25 \\
\hline Maximum & 30 & 21 & $\mathrm{NaN}$ & 28 & 28 & 28 & 30 \\
\hline Minimum & 21 & 19 & $\mathrm{NaN}$ & 17 & 16 & 27 & 16 \\
\hline StdDev & 1.3 & 0.4 & $\mathrm{NaN}$ & 1.3 & 2.4 & 0.4 & 2.1 \\
\hline
\end{tabular}

\begin{tabular}{|l|c|c|c|c|c|c|c|}
\hline pH in pH units & $7 / 21 / 2009$ & $7 / 29 / 2009$ & $7 / 30 / 2009$ & $7 / 31 / 2009$ & $8 / 2 / 2009$ & $8 / 4 / 2009$ & $\begin{array}{c}\text { All } \\
\text { Days }\end{array}$ \\
\hline \hline Maximum & 8.2 & 8.0 & 8.3 & 8.4 & 8.3 & 8.2 & 8.4 \\
\hline Minimum & 7.8 & 7.8 & 7.5 & 7.8 & 7.9 & 8.2 & 7.5 \\
\hline Median & 7.8 & 7.9 & 8.1 & 8.2 & 8.2 & 8.2 & 8.2 \\
\hline
\end{tabular}

\begin{tabular}{|l|c|c|c|c|c|c|c|}
\hline $\begin{array}{l}\text { Dissolved Oxygen } \\
\text { in milligrams per } \\
\text { liter }\end{array}$ & $7 / 21 / 2009$ & $7 / 29 / 2009$ & $7 / 30 / 2009$ & $7 / 31 / 2009$ & $8 / 2 / 2009$ & $8 / 4 / 2009$ & $\begin{array}{c}\text { All } \\
\text { Days }\end{array}$ \\
\hline \hline Average & $\mathrm{NaN}$ & 9.4 & $\mathrm{NaN}$ & 8.2 & 9.3 & 10.4 & 8.4 \\
\hline Maximum & $\mathrm{NaN}$ & 9.7 & $\mathrm{NaN}$ & 12.6 & 10.5 & 10.5 & 12.6 \\
\hline Minimum & $\mathrm{NaN}$ & 7.9 & $\mathrm{NaN}$ & 4.0 & 7.7 & 10.4 & 4.0 \\
\hline StdDev & $\mathrm{NaN}$ & 0.2 & $\mathrm{NaN}$ & 3.1 & 0.8 & 0.0 & 2.8 \\
\hline \begin{tabular}{l|c|c|c|c|c|c|} 
Dissolved Oxygen \\
percent saturation
\end{tabular} & $7 / 21 / 2009$ & $7 / 29 / 2009$ & $7 / 30 / 2009$ & $7 / 31 / 2009$ & $8 / 2 / 2009$ & $8 / 4 / 2009$ & $\begin{array}{c}\text { All } \\
\text { Days }\end{array}$ \\
\hline \hline Average & $\mathrm{NaN}$ & 109.1 & $\mathrm{NaN}$ & 98.8 & 113.1 & 124.7 & 101.7 \\
\hline Maximum & $\mathrm{NaN}$ & 117.7 & $\mathrm{NaN}$ & 146.7 & 127.7 & 125.3 & 146.7 \\
\hline Minimum & $\mathrm{NaN}$ & 94.0 & $\mathrm{NaN}$ & 48.1 & 96.3 & 123.9 & 48.1 \\
\hline StdDev & $\mathrm{NaN}$ & 2.3 & $\mathrm{NaN}$ & 37.6 & 8.9 & 0.5 & 34.1 \\
\hline
\end{tabular}

\begin{tabular}{|l|c|c|c|c|c|c|c|}
\hline $\begin{array}{l}\text { Turbidity in } \\
\text { Formazin } \\
\begin{array}{l}\text { Nephelometric } \\
\text { Units }\end{array}\end{array}$ & $7 / 21 / 2009$ & $7 / 29 / 2009$ & $7 / 30 / 2009$ & $7 / 31 / 2009$ & $8 / 2 / 2009$ & $8 / 4 / 2009$ & $\begin{array}{c}\text { All } \\
\text { Days }\end{array}$ \\
\hline \hline Average & 5 & 5 & 3 & 3 & 1 & 5 & 3 \\
\hline Maximum & 39 & 42 & 28 & 114 & 21 & 9.4 & 114 \\
\hline Minimum & 0.7 & 0.6 & 0.0 & 0.0 & 0.0 & 0.6 & 0.0 \\
\hline StdDev & 5 & 3 & 5 & 7 & 3 & 3 & 6 \\
\hline
\end{tabular}


Table 10. Water-quality statistics for North Central Basin and Skagit River, 2009.

[Average, median, maximum, minimum, standard deviation (StdDev), and number of observations (n) for temperature in degrees Celsius, salinity in pratical salinity units, $\mathrm{pH}$ in $\mathrm{pH}$ units, dissolved-oxygen in milligrams per liter and percent saturation, and turbidity in Formazin Nephelometric Units. NaN was used for parameters which did not meet data-quality standards.]

\begin{tabular}{|l|c|}
\hline \multicolumn{2}{|c|}{ North Central } \\
\hline \hline $\mathrm{n}$ & 1,104 \\
\hline $\begin{array}{l}\text { Temperature in } \\
\text { degrees Celsius }\end{array}$ & $8 / 3 / 2009$ \\
\hline \hline Average & 13.9 \\
\hline Maximum & 15.5 \\
\hline Minimum & 12.3 \\
\hline StdDev & 0.9 \\
\hline
\end{tabular}

\begin{tabular}{|c|c|c|}
\hline \multicolumn{3}{|c|}{ Skagit River } \\
\hline \hline 578 & 1,789 & 2,367 \\
\hline $8 / 1 / 2009$ & $8 / 2 / 2009$ & All Days \\
\hline \hline 17.1 & 16.7 & 16.8 \\
\hline 23.4 & 23.8 & 23.8 \\
\hline 16.8 & 15.5 & 15.5 \\
\hline 0.4 & 1.5 & 1.4 \\
\hline
\end{tabular}

\begin{tabular}{|l|c|}
\hline $\begin{array}{l}\text { Salinity in practical } \\
\text { salinity units }\end{array}$ & $8 / 3 / 2009$ \\
\hline \hline Average & 29 \\
\hline Maximum & 30 \\
\hline Minimum & 21 \\
\hline StdDev & 0.9 \\
\hline
\end{tabular}

\begin{tabular}{|l|l|l|}
\hline $8 / 1 / 2009$ & $8 / 2 / 2009$ & All Days \\
\hline \hline
\end{tabular}

\begin{tabular}{|l|c|}
\hline pH in pH units & $8 / 3 / 2009$ \\
\hline \hline Maximum & 8.3 \\
\hline Minimum & 7.9 \\
\hline Median & 8.1 \\
\hline
\end{tabular}

\begin{tabular}{|l|l|l|}
\hline \hline 0.0 & 0.1 & 0.1 \\
\hline 0.0 & 6.0 & 6.0 \\
\hline 0.0 & 0.0 & 0.0 \\
\hline 0.0 & 0.6 & 0.5 \\
\hline
\end{tabular}

\begin{tabular}{|c|c|c|}
\hline $8 / 1 / 2009$ & $8 / 2 / 2009$ & All Days \\
\hline \hline 7.9 & 8.8 & 8.8 \\
\hline 7.3 & 6.6 & 6.6 \\
\hline 7.3 & 7.4 & 7.4 \\
\hline
\end{tabular}

\begin{tabular}{|l|c|}
\hline $\begin{array}{l}\text { Dissolved Oxygen in } \\
\text { milligrams per liter }\end{array}$ & $8 / 3 / 2009$ \\
\hline \hline Average & 7.1 \\
\hline Maximum & 9.4 \\
\hline Minimum & 5.9 \\
\hline StdDev & 0.7 \\
\hline
\end{tabular}

\begin{tabular}{|l|c|}
\hline $\begin{array}{l}\text { Dissolved Oxygen } \\
\text { percent saturation }\end{array}$ & $8 / 3 / 2009$ \\
\hline \hline Average & 82.1 \\
\hline Maximum & 107.9 \\
\hline Minimum & 69.7 \\
\hline StdDev & 7.7 \\
\hline
\end{tabular}

\begin{tabular}{|c|c|c|}
\hline $8 / 1 / 2009$ & $8 / 2 / 2009$ & All Days \\
\hline \hline 9.0 & 10.0 & 9.7 \\
\hline 16.2 & 18.7 & 18.7 \\
\hline 7.5 & 7.8 & 7.5 \\
\hline 1.4 & 1.3 & 1.4 \\
\hline $8 / 1 / 2009$ & $8 / 2 / 2009$ & All Days \\
\hline \hline
\end{tabular}

\begin{tabular}{|l|c|}
\hline $\begin{array}{l}\text { Turbidity in Formazin } \\
\text { Nephelometric Units }\end{array}$ & $8 / 3 / 2009$ \\
\hline \hline Average & $\mathrm{NaN}$ \\
\hline Maximum & $\mathrm{NaN}$ \\
\hline Minimum & $\mathrm{NaN}$ \\
\hline StdDev & $\mathrm{NaN}$ \\
\hline
\end{tabular}

\begin{tabular}{|c|c|c|}
\hline \hline 92.8 & 102.4 & 100.1 \\
\hline 166.9 & 187.3 & 187.3 \\
\hline 77.9 & 89.3 & 77.9 \\
\hline 13.9 & 11.7 & 12.9 \\
\hline $8 / 1 / 2009$ & $8 / 2 / 2009$ & All Days \\
\hline \hline 22 & $\mathrm{NaN}$ & 22 \\
\hline 29 & $\mathrm{NaN}$ & 29 \\
\hline 10 & $\mathrm{NaN}$ & 10 \\
\hline 2 & $\mathrm{NaN}$ & 2 \\
\hline
\end{tabular}




\section{South Salish Sea}

The South Salish Sea region contains three basins: Hood Canal (HC), South Central Puget Sound, hereafter referred to as South Central (SC), and South Puget Sound (SP). Hood Canal was monitored on four days from July 28 to August 3. South Central was monitored on August 3 and 4, and South Puget Sound was monitored on July 27, 2009. Air temperatures in the south Salish Sea ranged from $4.4^{\circ} \mathrm{C}$ at night in Quilcene, Wash. to a day time high of $40.0^{\circ} \mathrm{C}$ in Olympia, Wash. Average air temperatures for the month of July ranged from 19.3 to $20.8^{\circ} \mathrm{C}$ (National Oceanic and Atmospheric Administration, 2009). Results for the south Salish Sea TJWQP monitoring by parameter are shown in figures 18 to 22. Results are organized by basin in tables 11 and 12 .

Hood Canal temperatures (table 11) ranged from 13.4 to $27.2{ }^{\circ} \mathrm{C}$ and averaged $19.9{ }^{\circ} \mathrm{C}$ $(n=6,312)$. Daily averages of surface-water temperatures decreased as the canoes traveled from southern Hood Canal to northern Hood Canal where there is more input of cool water from the Strait of Juan de Fuca. The salinity ranged from 0.7 to $31 \mathrm{psu}$ and had an average salinity of $27 \mathrm{psu}(\mathrm{n}=6,312)$, with the lowest salinities recorded at the mouth of the Skokomish River. Hood Canal pH ranged from 7.0 to 8.4 $\mathrm{pH}$ units, with a median of $8.1 \mathrm{pH}$ units $(\mathrm{n}=6,312)$. Dissolved-oxygen readings from the first two days of travel in the southern portion of Hood Canal were not analyzed because they did not pass qualitycontrol criteria; the northern portion of Hood Canal had values ranging from 4.0 to $13.4 \mathrm{mg} / \mathrm{L}$, with an average concentration of $6.4 \mathrm{mg} / \mathrm{L}(\mathrm{n}=2,791)$. Dissolved-oxygen saturation levels ranged from 52.2 to 152.6 percent. Turbidity ranged from 0.0 to $190 \mathrm{FNU}$ and averaged $7 \mathrm{FNU}(\mathrm{n}=6,047)$.

In 2009 canoes traveled through only the northern portion of the South Central Basin. The surfacewater temperature in this portion of the region had a minimum of $13.2{ }^{\circ} \mathrm{C}$ and a maximum of $20.5^{\circ} \mathrm{C}$ (table 12) with an average of $15.7^{\circ} \mathrm{C}(\mathrm{n}=1,739)$. Salinity ranged from 17 to $30 \mathrm{psu}$ and averaged $28 \mathrm{psu}$ $(\mathrm{n}=1,739)$. The $\mathrm{pH}$ ranged from 8.0 and $8.5 \mathrm{pH}$ units with a median of $8.2 \mathrm{pH}$ units $(\mathrm{n}=1,739)$ during the two-day monitoring period. Dissolved-oxygen concentration ranged from 5.3 to $12.7 \mathrm{mg} / \mathrm{L}$ and averaged $8.3 \mathrm{mg} / \mathrm{L}(\mathrm{n}=1,739)$. Dissolved-oxygen saturation showed a minimum of 60.9 percent and a maximum of 146.5 percent and averaged 99.0 percent. Turbidity in the northern portion of the basin ranged from 0.3 to $180 \mathrm{FNU}$ and averaged $27 \mathrm{FNU}(\mathrm{n}=786)$. Rafts of biological film were observed on the water surface (fig. 17), and plankton were observed in South Central Basin during the Tribal Journey. 


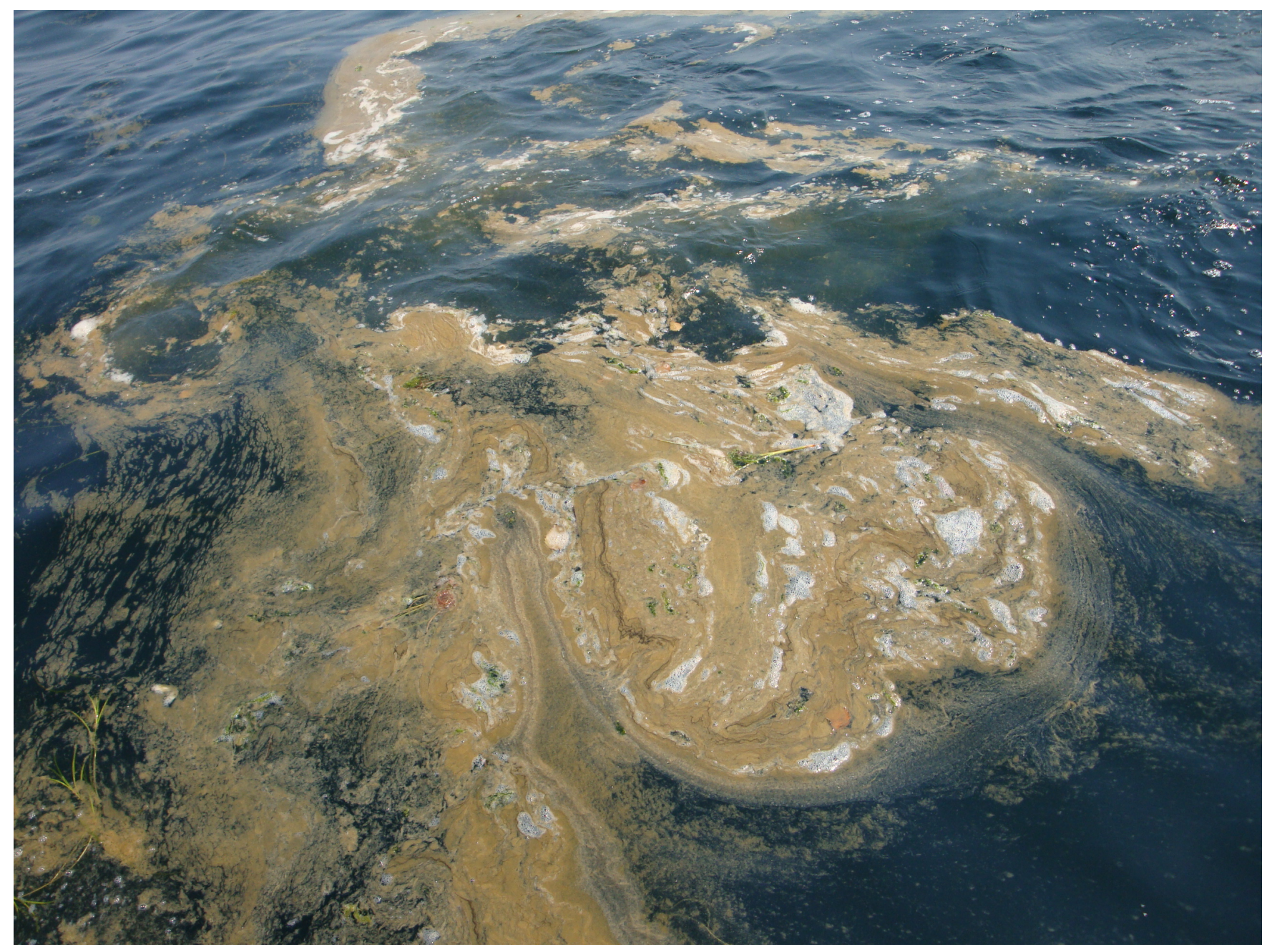

Figure 17. Biological growth observed in South Central Basin, August 2009. Photo by E. Grossman.

Surface-water temperatures (table 12) in South Puget Sound Basin ranged from 16.0 to $23.4^{\circ} \mathrm{C}$ and an average of $18.6^{\circ} \mathrm{C}(\mathrm{n}=1,453)$. Salinity ranged from 28 to $30 \mathrm{psu}$, and an average of $29 \mathrm{psu}(\mathrm{n}=1,453)$. The $\mathrm{pH}$ ranged from 8.1 to $8.5 \mathrm{pH}$ units, with a median of $8.1 \mathrm{pH}$ units $(\mathrm{n}=1,453)$. Dissolved-oxygen results are not summarized because the data did not meet data-quality criteria. The turbidity for South Puget Sound Basin ranged from 0.0 to 84 FNU and averaged 9 FNU $(n=1,453)$. The canoe and support boat crews observed several large jellyfish (possibly Cyanea capillata) and a persistent high density of quarter-sized plankton clusters throughout the basin. 


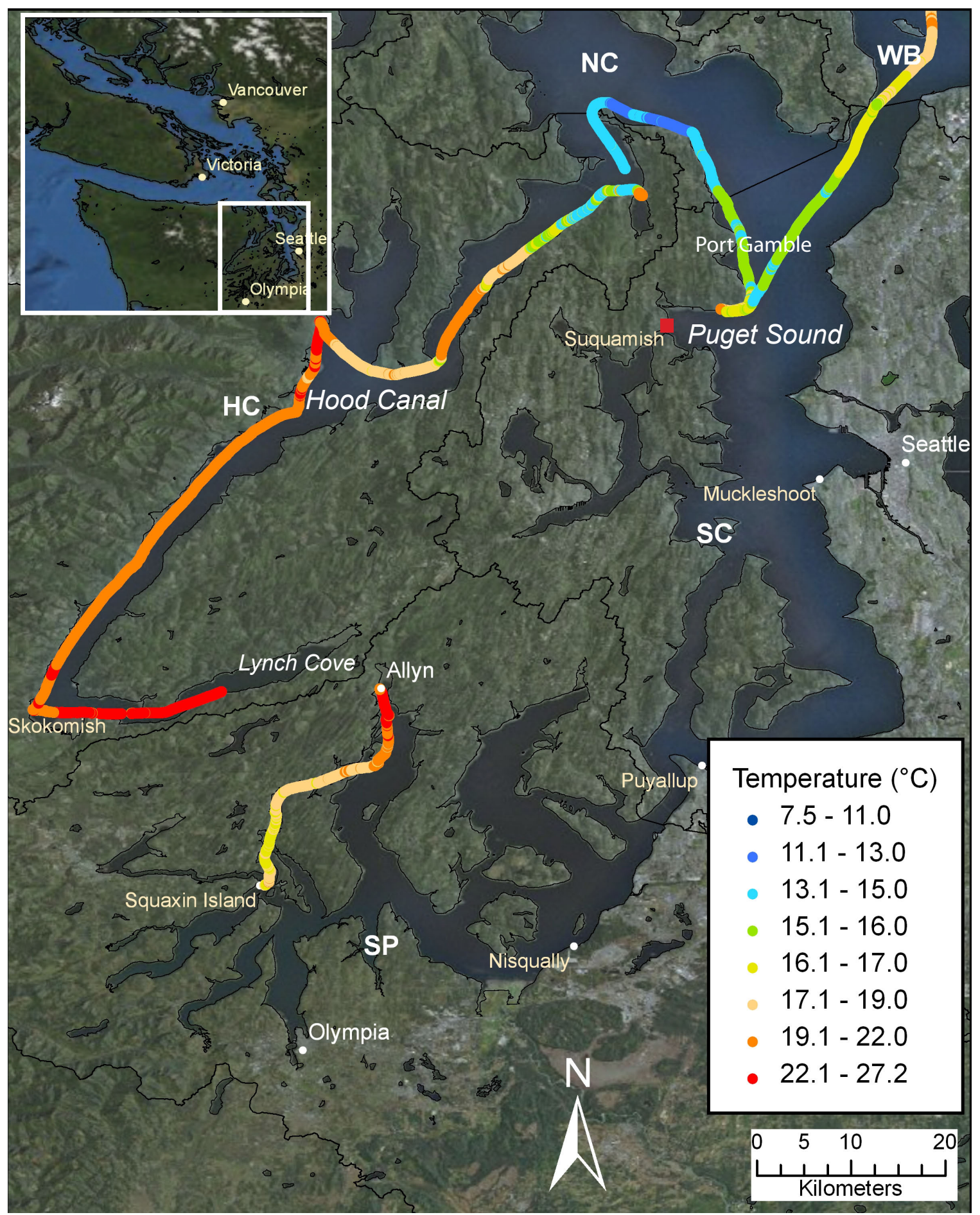

Figure 18. Surface-water temperature recorded in degrees Celsius in the southern Salish Sea region from July 21 to August 3, 2009. This region includes results from the Hood Canal, South Central Puget Sound, and South Puget Sound Basins. 


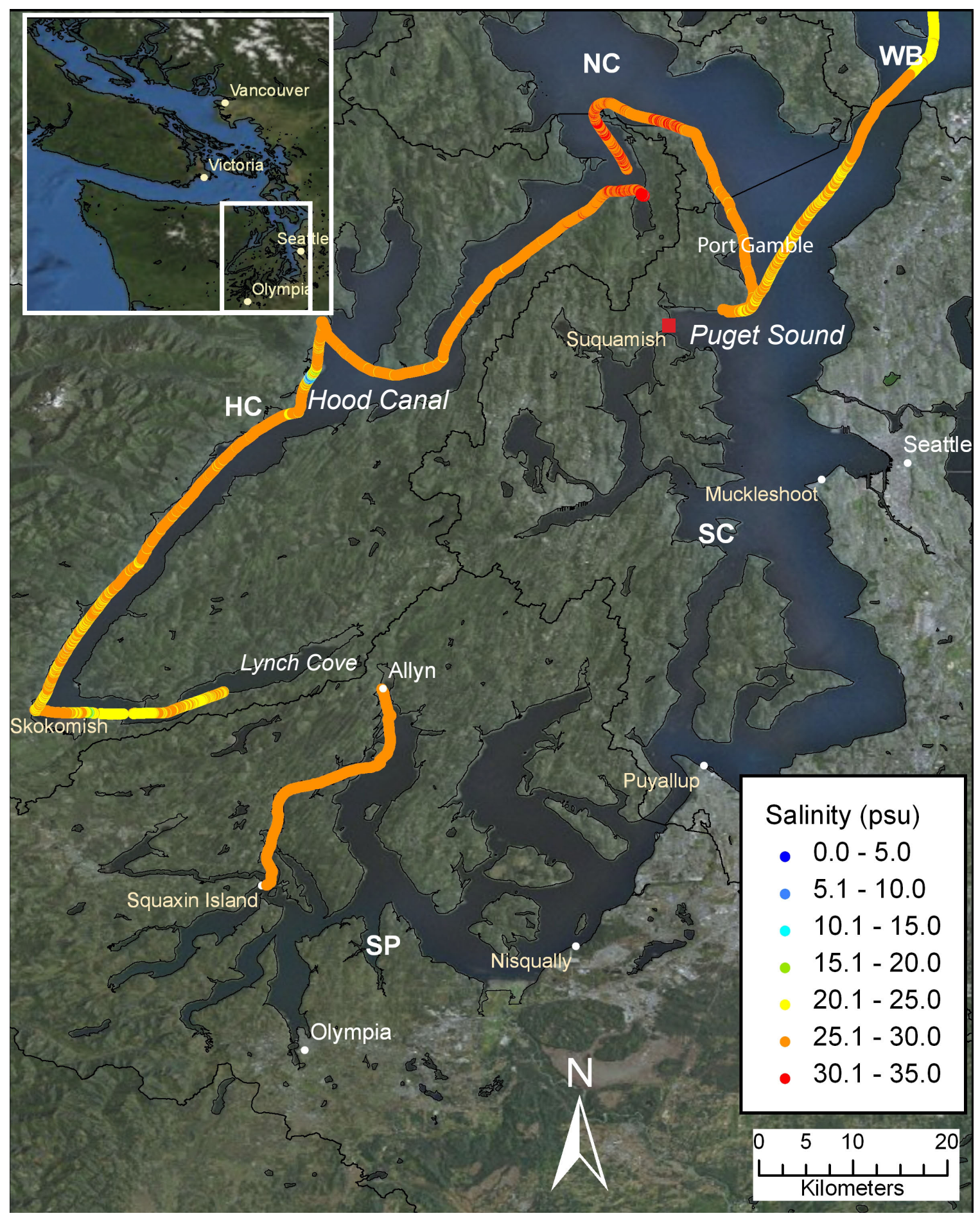

Figure 19. Surface-water salinity recorded in practical salinity units in the southern Salish Sea region from July 21 to August 3, 2009. This region includes results from the Hood Canal, South Central Puget Sound, and South Puget Sound Basins. 


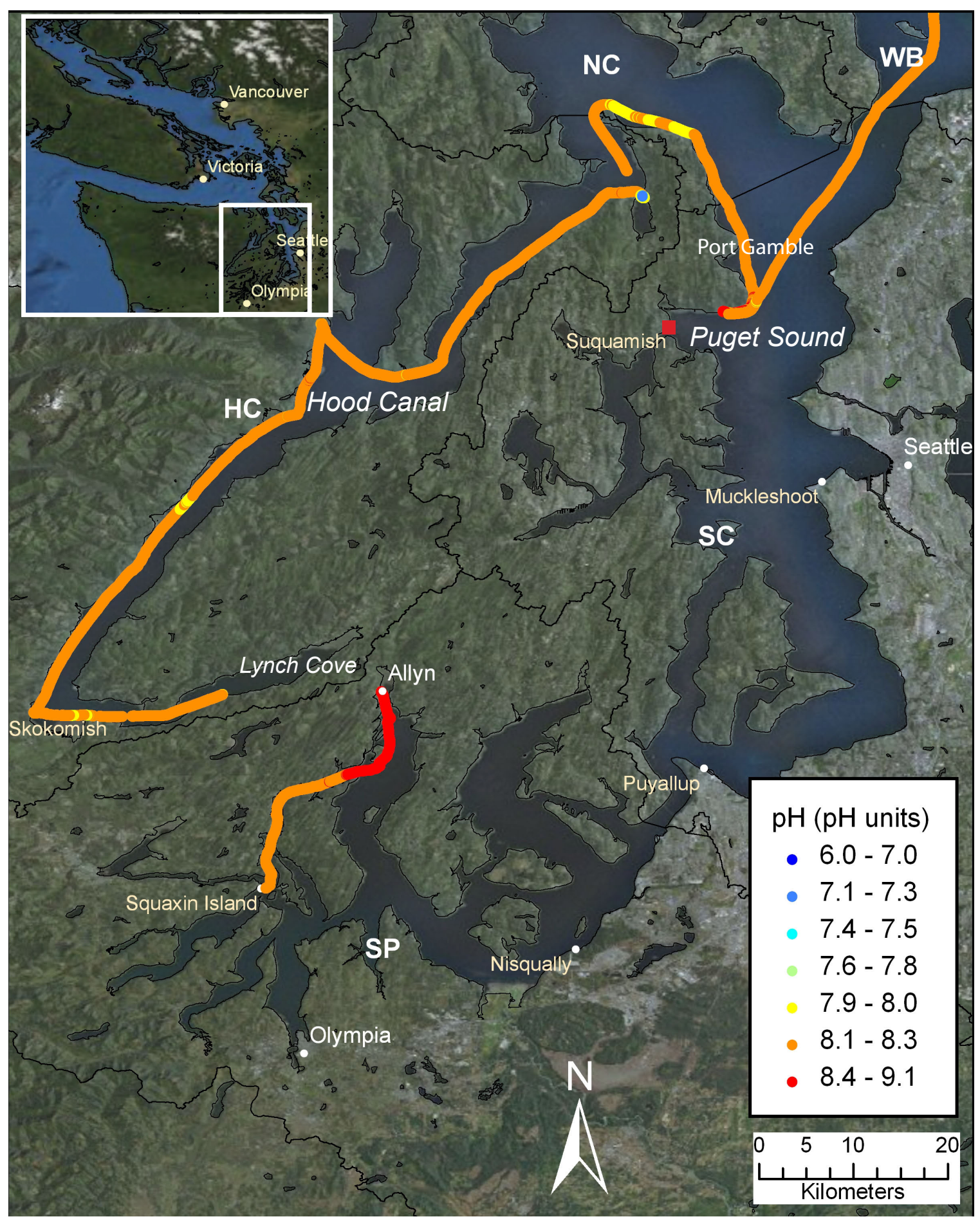

Figure 20. Surface-water pH recorded in standard units in the southern Salish Sea region from July 21 to August 3, 2009. This region includes results from the Hood Canal, South Central Puget Sound, and South Puget Sound Basins. 


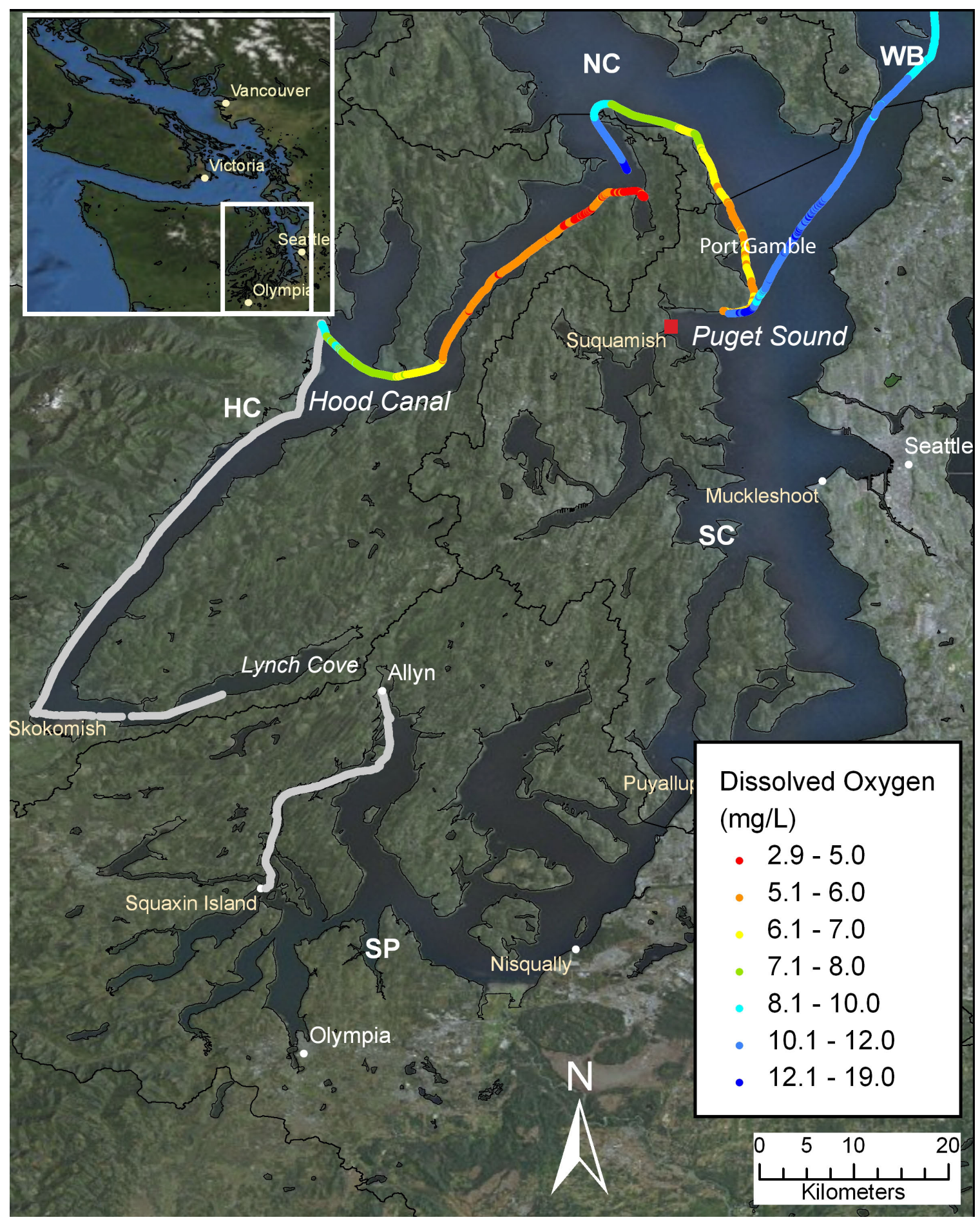

Figure 21. Surface-water dissolved oxygen recorded in milligrams per liter in the southern Salish Sea region from July 21 to August 3, 2009. This region includes results from the Hood Canal, South Central Puget Sound, and South Puget Sound Basins. 


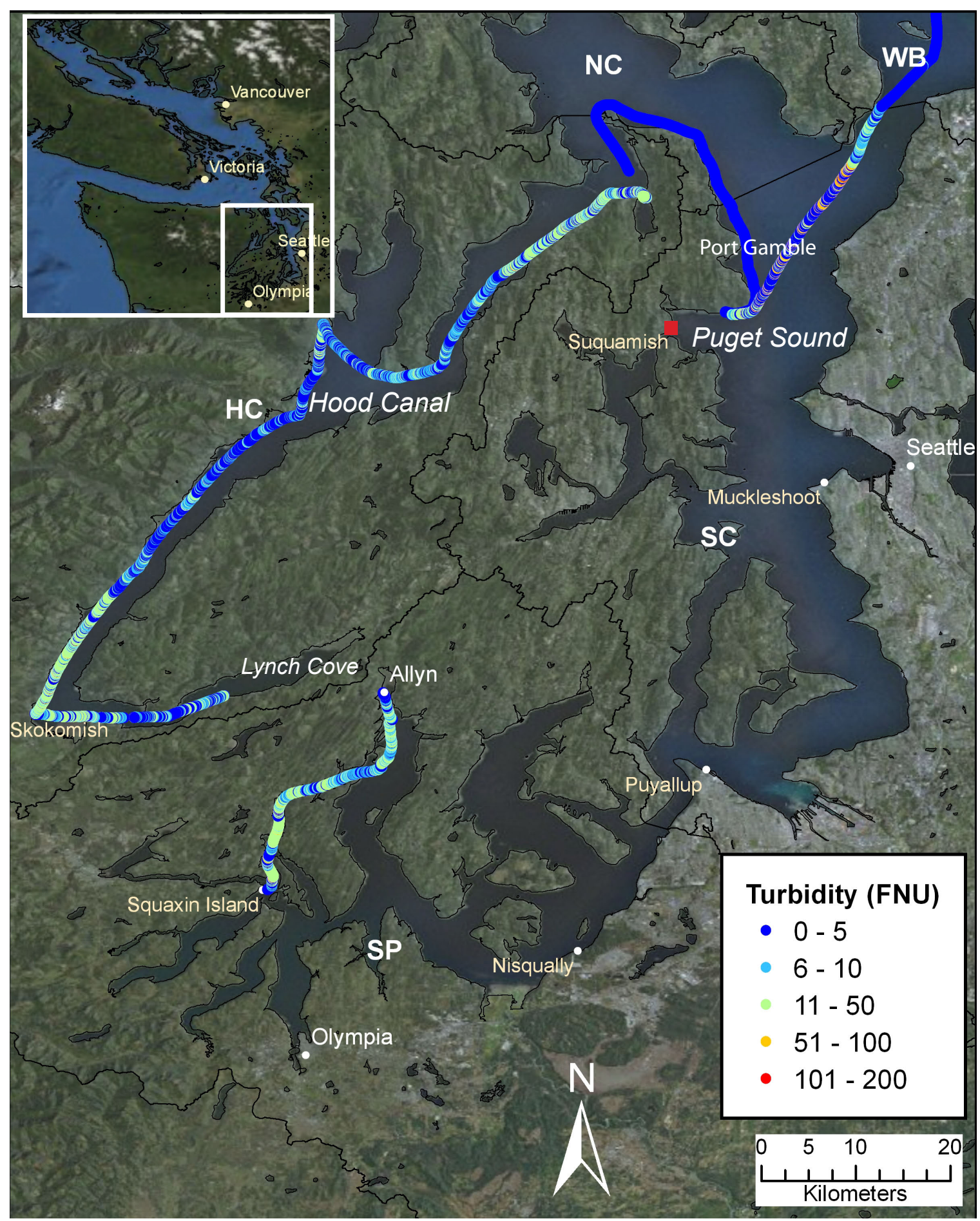

Figure 22. Turbidity recorded in Formazin Nephelometric Units in the southern Salish Sea region from July 21 to August 3, 2009. This region includes results from the Hood Canal, South Central Puget Sound, and South Puget Sound Basins. 
Table 11. Water-quality statistics for Hood Canal Basin, 2009.

[Average, median, maximum, minimum, standard deviation (StdDev), and number of observations (n) for temperature in degrees Celsius, salinity in pratical salinity units, $\mathrm{pH}$ in $\mathrm{pH}$ units, dissolved-oxygen in milligrams per liter and percent saturation, and turbidity in Formazin Nephelometric Units. NaN was used for parameters which did not meet data-quality standards.]

\begin{tabular}{|l|c|c|c|c|c|}
\hline \multicolumn{6}{|c|}{ Hood Canal } \\
\hline \hline $\mathrm{n}$ & 1,242 & 2,279 & 2,526 & 265 & 6,312 \\
\hline
\end{tabular}

\begin{tabular}{|c|c|c|c|c|c|}
\hline $\begin{array}{l}\text { Temperature in } \\
\text { degrees Celsius }\end{array}$ & $7 / 28 / 2009$ & $7 / 30 / 2009$ & $7 / 31 / 2009$ & $8 / 3 / 2009$ & $\begin{array}{l}\text { All } \\
\text { Days }\end{array}$ \\
\hline Average & 22.1 & 21.5 & 18.0 & 14.2 & 19.9 \\
\hline Maximum & 27.2 & 23.8 & 21.6 & 15.0 & 27.2 \\
\hline Minimum & 19.9 & 17.8 & 14.1 & 13.4 & 13.4 \\
\hline StdDev & 1.5 & 0.7 & 2.1 & 0.3 & 2.6 \\
\hline
\end{tabular}

\begin{tabular}{|l|c|c|c|c|c|}
\hline $\begin{array}{l}\text { Salinity in practical } \\
\text { salinity units }\end{array}$ & $7 / 28 / 2009$ & $7 / 30 / 2009$ & $7 / 31 / 2009$ & $8 / 3 / 2009$ & $\begin{array}{c}\text { All } \\
\text { Days }\end{array}$ \\
\hline \hline Average & 25 & 26 & 29 & 29 & 27 \\
\hline Maximum & 27 & 29 & 31 & 30 & 31 \\
\hline Minimum & 15 & 2.8 & 0.7 & 11 & 0.7 \\
\hline StdDev & 1.6 & 2.7 & 1.5 & 1.5 & 2.5 \\
\hline
\end{tabular}

\begin{tabular}{|l|c|c|c|c|c|}
\hline pH in pH units & $7 / 28 / 2009$ & $7 / 30 / 2009$ & $7 / 31 / 2009$ & $8 / 3 / 2009$ & $\begin{array}{c}\text { All } \\
\text { Days }\end{array}$ \\
\hline \hline Maximum & 8.3 & 8.4 & 8.3 & 8.2 & 8.4 \\
\hline Minimum & 7.9 & 7.7 & 7.0 & 8.0 & 7.0 \\
\hline Median & 8.1 & 8.1 & 8.1 & 8.1 & 8.1 \\
\hline
\end{tabular}

\begin{tabular}{|l|c|c|c|c|c|}
\hline $\begin{array}{l}\text { Dissolved Oxygen } \\
\text { in milligrams per } \\
\text { liter }\end{array}$ & $7 / 28 / 2009$ & $7 / 30 / 2009$ & $7 / 31 / 2009$ & $8 / 3 / 2009$ & $\begin{array}{c}\text { All } \\
\text { Days }\end{array}$ \\
\hline \hline Average & $\mathrm{NaN}$ & $\mathrm{NaN}$ & 5.9 & 11.3 & 6.4 \\
\hline Maximum & $\mathrm{NaN}$ & $\mathrm{NaN}$ & 8.8 & 13.4 & 13.4 \\
\hline Minimum & $\mathrm{NaN}$ & $\mathrm{NaN}$ & 4.0 & 9.4 & 4.0 \\
\hline StdDev & $\mathrm{NaN}$ & $\mathrm{NaN}$ & 1.1 & 0.9 & 2.0 \\
\hline
\end{tabular}

\begin{tabular}{|l|c|c|c|c|c|}
\hline $\begin{array}{l}\text { Dissolved Oxygen } \\
\text { percent saturation }\end{array}$ & $7 / 28 / 2009$ & $7 / 30 / 2009$ & $7 / 31 / 2009$ & $8 / 3 / 2009$ & $\begin{array}{c}\text { All } \\
\text { Days }\end{array}$ \\
\hline \hline Average & $\mathrm{NaN}$ & $\mathrm{NaN}$ & 73.6 & 132.3 & 79.2 \\
\hline Maximum & $\mathrm{NaN}$ & $\mathrm{NaN}$ & 116.1 & 152.6 & 152.6 \\
\hline Minimum & $\mathrm{NaN}$ & $\mathrm{NaN}$ & 52.2 & 108.5 & 52.2 \\
\hline StdDev & $\mathrm{NaN}$ & $\mathrm{NaN}$ & 15.5 & 10.3 & 22.9 \\
\hline
\end{tabular}

\begin{tabular}{|l|c|c|c|c|c|}
\hline $\begin{array}{l}\text { Turbidity in } \\
\text { Formazin } \\
\begin{array}{l}\text { Nephelometric } \\
\text { Units }\end{array}\end{array}$ & $7 / 28 / 2009$ & $7 / 30 / 2009$ & $7 / 31 / 2009$ & $8 / 3 / 2009$ & $\begin{array}{c}\text { All } \\
\text { Days }\end{array}$ \\
\hline \hline Average & 4.0 & 8.0 & 8.1 & $\mathrm{NaN}$ & 7.2 \\
\hline Maximum & 54 & 194 & 153 & $\mathrm{NaN}$ & 194 \\
\hline Minimum & 0.0 & 0.0 & 0.0 & $\mathrm{NaN}$ & 0.0 \\
\hline StdDev & 6.2 & 10.3 & 9.0 & $\mathrm{NaN}$ & 9.2 \\
\hline
\end{tabular}


Table 12. Water-quality statistics for South Central and South Sound Basins, 2009.

[Average, median, maximum, minimum, standard deviation (StdDev), and number of observations (n) for temperature in degrees Celsius, salinity in pratical salinity units, $\mathrm{pH}$ in $\mathrm{pH}$ units, dissolved-oxygen in milligrams per liter and percent saturation, and turbidity in Formazin Nephelometric Units. NaN was used for parameters which did not meet data-quality standards.]

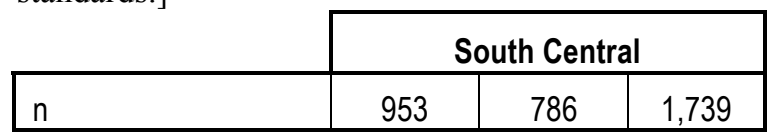

\begin{tabular}{|l|c|c|c|}
\hline $\begin{array}{l}\text { Temperature in } \\
\text { degrees Celsius }\end{array}$ & $8 / 3 / 2009$ & $8 / 4 / 2009$ & $\begin{array}{c}\text { All } \\
\text { Days }\end{array}$ \\
\hline \hline Average & 15.6 & 15.8 & 15.7 \\
\hline Maximum & 20.5 & 16.7 & 20.5 \\
\hline Minimum & 13.5 & 13.2 & 13.2 \\
\hline StdDev & 0.9 & 0.7 & 0.8 \\
\hline
\end{tabular}

\begin{tabular}{|l|c|c|c|}
\hline $\begin{array}{l}\text { Salinity in practical } \\
\text { salinity units }\end{array}$ & $8 / 3 / 2009$ & $8 / 4 / 2009$ & $\begin{array}{c}\text { All } \\
\text { Days }\end{array}$ \\
\hline \hline Average & 29 & 27 & 28 \\
\hline Maximum & 30 & 30 & 30 \\
\hline Minimum & 18 & 20 & 18 \\
\hline StdDev & 0.9 & 2.3 & 2.0 \\
\hline
\end{tabular}

\begin{tabular}{|l|c|c|c|}
\hline pH in pH units & $8 / 3 / 2009$ & $8 / 4 / 2009$ & $\begin{array}{c}\text { All } \\
\text { Days }\end{array}$ \\
\hline \hline Maximum & 8.5 & 8.3 & 8.5 \\
\hline Minimum & 8.1 & 8.0 & 8.0 \\
\hline Median & 8.2 & 8.2 & 8.2 \\
\hline
\end{tabular}

\begin{tabular}{|l|c|c|c|}
\hline $\begin{array}{l}\text { Dissolved Oxygen in } \\
\text { milligrams per liter }\end{array}$ & $8 / 3 / 2009$ & $8 / 4 / 2009$ & $\begin{array}{c}\text { All } \\
\text { Days }\end{array}$ \\
\hline \hline Average & 5.9 & 11.2 & 8.3 \\
\hline Maximum & 7.2 & 12.7 & 12.7 \\
\hline Minimum & 5.3 & 8.9 & 5.3 \\
\hline StdDev & 0.2 & 0.7 & 2.7 \\
\hline
\end{tabular}

\begin{tabular}{|l|c|c|c|}
\hline $\begin{array}{l}\text { Dissolved Oxygen } \\
\text { percent saturation }\end{array}$ & $8 / 3 / 2009$ & $8 / 4 / 2009$ & $\begin{array}{c}\text { All } \\
\text { Days }\end{array}$ \\
\hline \hline Average & 71.0 & 132.9 & 99.0 \\
\hline Maximum & 86.7 & 146.5 & 146.5 \\
\hline Minimum & 60.9 & 102.9 & 60.9 \\
\hline StdDev & 3.3 & 8.5 & 31.4 \\
\hline
\end{tabular}

\begin{tabular}{|l|c|c|c|}
\hline $\begin{array}{l}\text { Turbidity in Formazin } \\
\text { Nephelometric Units }\end{array}$ & $8 / 3 / 2009$ & $8 / 4 / 2009$ & $\begin{array}{c}\text { All } \\
\text { Days }\end{array}$ \\
\hline \hline Average & $\mathrm{NaN}$ & 27 & 27 \\
\hline Maximum & $\mathrm{NaN}$ & 175 & 175 \\
\hline Mlinimum & $\mathrm{NaN}$ & 0.3 & 0.3 \\
\hline
\end{tabular}

\begin{tabular}{|c|}
\hline South Sound \\
\hline \hline 1453 \\
\hline $7 / 27 / 2009$ \\
\hline 18.6 \\
\hline 23.4 \\
\hline 16.0 \\
\hline 2.1 \\
\hline $7 / 27 / 2009$ \\
\hline 29 \\
\hline 30 \\
\hline 28 \\
\hline 0.2 \\
\hline \hline
\end{tabular}




\section{Pacific Coast and Juan de Fuca Strait}

In 2009 the TJWQP monitoring area was expanded to include the Pacific coast off of Washington State. Water-quality conditions along the rugged Pacific Coast route were monitored by the Quinault Nation, and this summary covered the Pacific and Juan de Fuca Basins. The Pacific Coast Basin was monitored July 26, 2009, and the Juan de Fuca Basin (JF) was monitored July 29, 2009. The Songhees Nation also pulled a YSI sonde from Vancouver Island to Port Angeles, but the data quality was not validated because the sonde could not be recovered. The maximum air temperature was $31.1{ }^{\circ} \mathrm{C}$ for the Quillayute, Wash. area during July 2009 (National Oceanic and Atmospheric Administration, 2009). A maximum temperature of $35.0^{\circ} \mathrm{C}$ was recorded at Victoria International Airport in July 2009 during the time of the Tribal Journey. Results for the Pacific Coast and Juan de Fuca Basins during the TJWQP monitoring by parameter are shown in figures 23 to 25 . The surface water temperature (table 13) for the Pacific Coast Basin ranged from 9.7 to $16.2^{\circ} \mathrm{C}$ and averaged $11.0^{\circ} \mathrm{C}(\mathrm{n}=4,394)$. Salinity and $\mathrm{pH}$ data failed to meet the audit criteria and are not reported here. Dissolved-oxygen concentration ranged from 6.9 to $9.7 \mathrm{mg} / \mathrm{L}$ and averaged $7.7 \mathrm{mg} / \mathrm{L}(\mathrm{n}=4,394)$. Dissolved-oxygen saturation levels ranged from 75.5 to 103.9 percent and averaged 86.5 percent. The turbidity ranged from 0.0 to $85 \mathrm{FNU}$ and averaged 6 FNU (n=4,394).

Juan de Fuca basin surface-water temperatures (table 13) ranged between a minimum of 7.5 to $13.7^{\circ} \mathrm{C}$ and averaged $10.2^{\circ} \mathrm{C}(\mathrm{n}=3,153)$. The Juan de Fuca Basin had the coolest surface-water temperature of all basins monitored in 2009. Salinities ranged from 3.7 to 34 psu and averaged $32 \mathrm{psu}$ $(\mathrm{n}=3,151)$. The $\mathrm{pH}$ values ranged from 7.5 to $7.9 \mathrm{pH}$ units and the median was $7.7 \mathrm{pH}$ units $(\mathrm{n}=3,151)$. Dissolved-oxygen concentration ranged from 2.9 to $8.2 \mathrm{mg} / \mathrm{L}$ and averaged $5.7 \mathrm{mg} / \mathrm{L}(\mathrm{n}=3,151)$. Dissolved-oxygen saturation was below 100 percent for all measurements with a range of 29.9 to 90.1 percent and an average of 61.9 percent. The turbidity ranged from 0.0 to 83 FNU and averaged 6.3 FNU $(\mathrm{n}=3,151)$. 

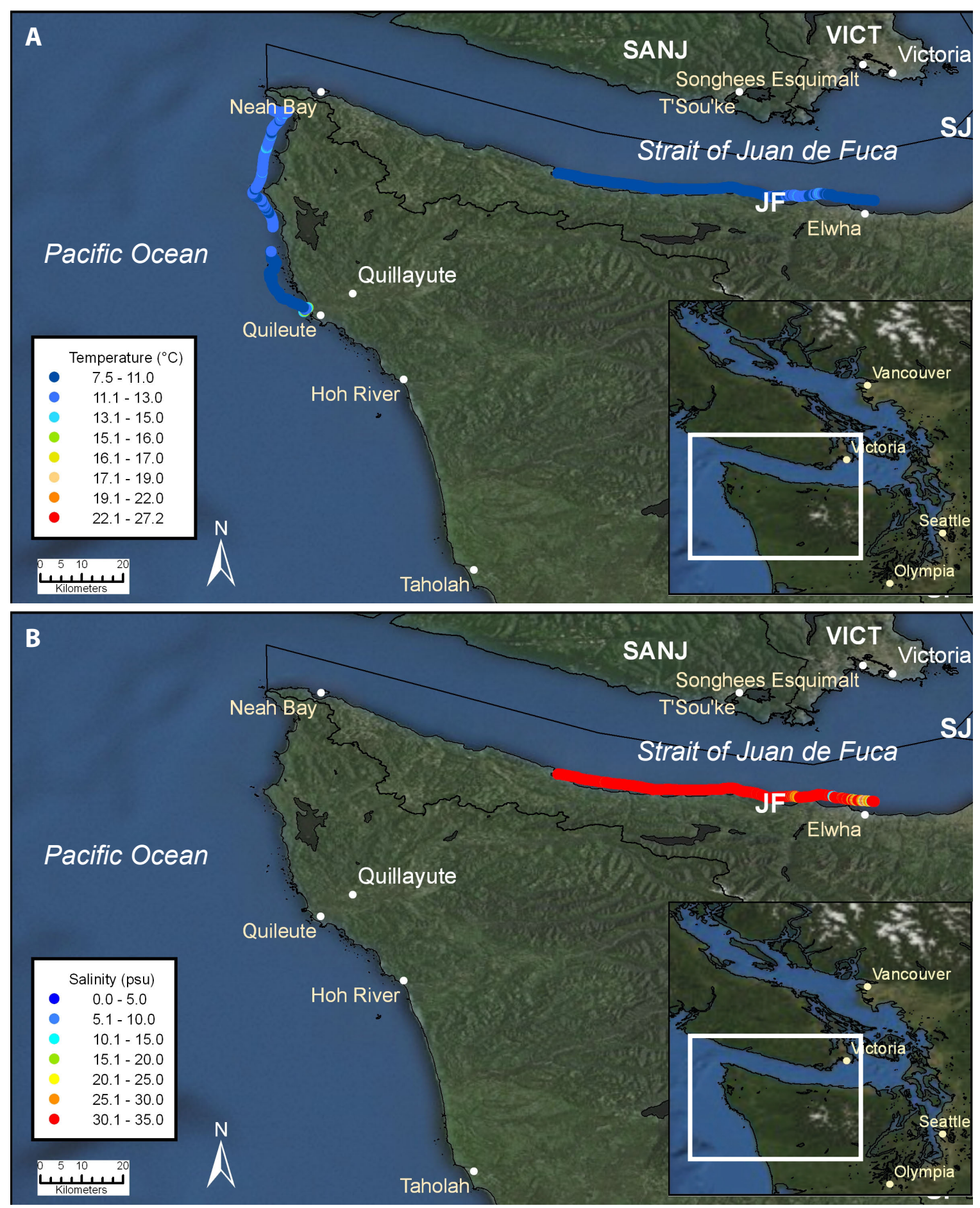

Figure 23. Surface-water temperature $(A)$ recorded in degrees Celsius and salinity $(B)$ recorded in practical salinity units in the west Salish Sea from July 26 to 29, 2009. This region includes results from the Pacific Coast and Juan de Fuca Basins. 

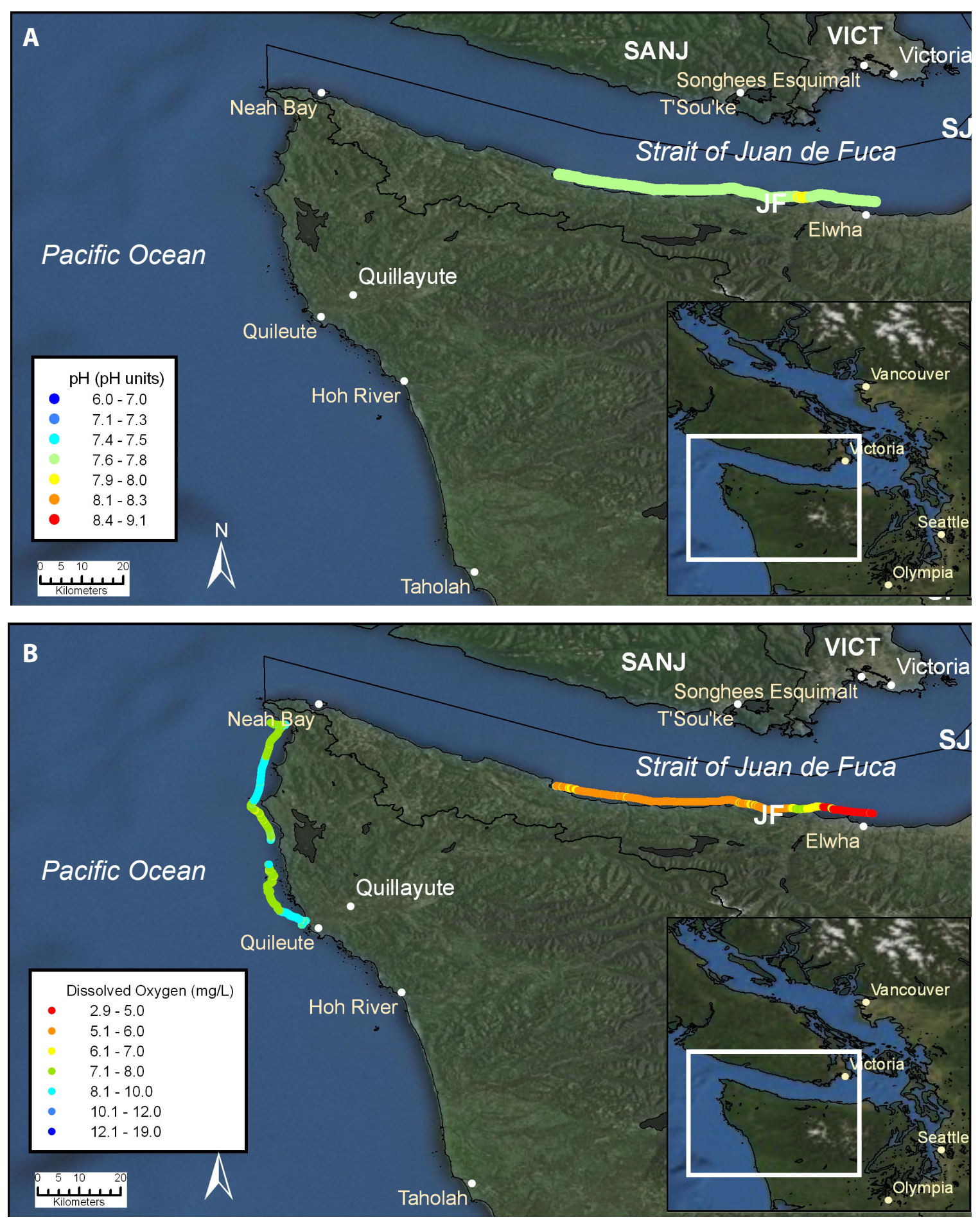

Figure 24. Surface-water pH (A) recorded in standard units and dissolved oxygen (B) recorded in milligrams per liter in the west Salish Sea from July 26 to 29, 2009. This region includes results from the Pacific Coast and Juan de Fuca Basins. 


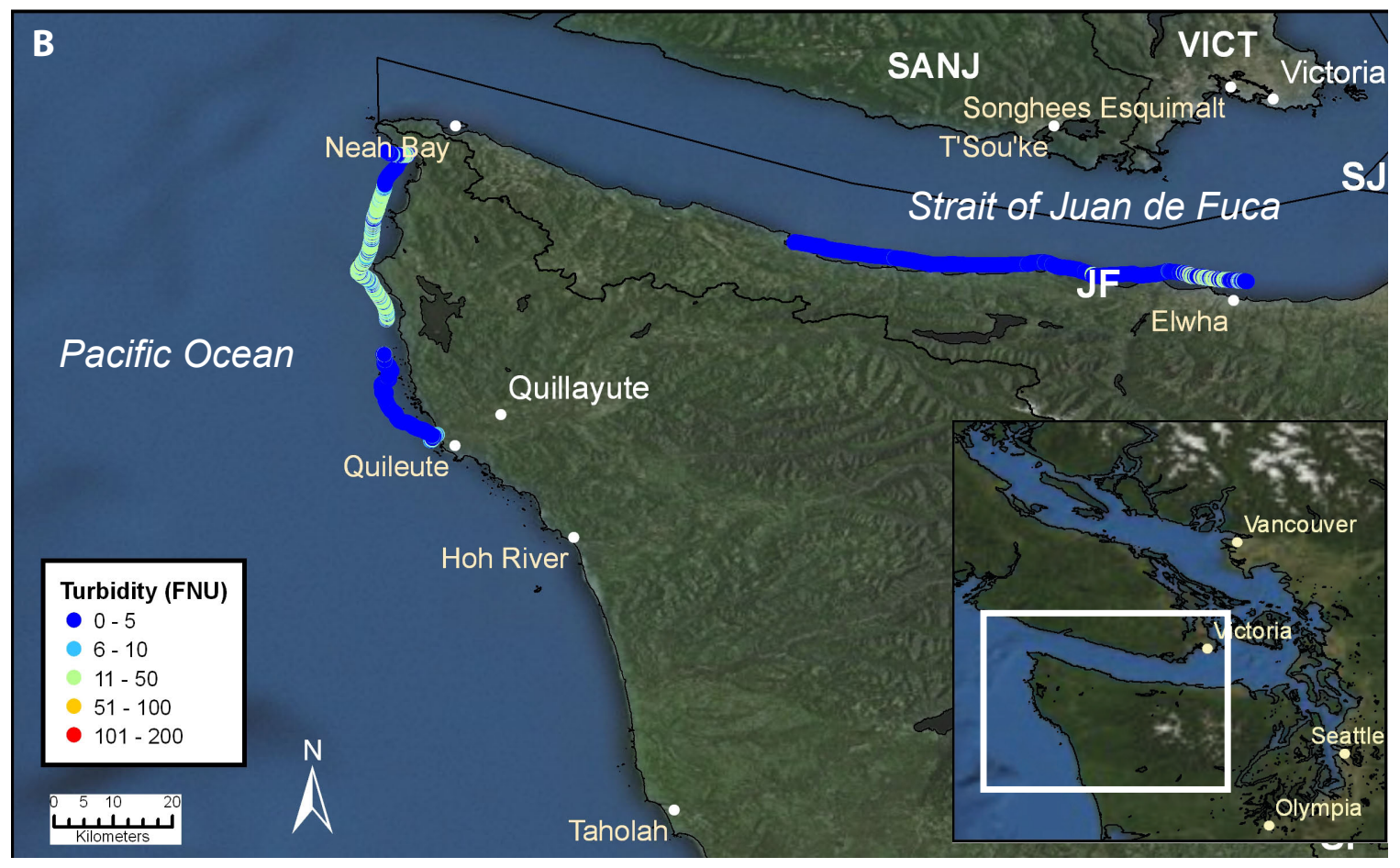

Figure 25. Surface-water turbidity measured in Formazin Nephelometric Units in the west Salish Sea from July 26 to 29,2009 . This region includes results from the Pacific Coast and Juan de Fuca Basins. 
Table 13. Water-quality statistics for Pacific Coast and Juan de Fuca Basins, 2009.

[Average, median, maximum, minimum, standard deviation (StdDev), and number of observations (n) for temperature in degrees Celsius, salinity in pratical salinity units, $\mathrm{pH}$ in $\mathrm{pH}$ units, dissolved-oxygen in milligrams per liter and percent saturation, and turbidity in Formazin Nephelometric Units. NaN was used for parameters which did not meet data-quality standards.]

\begin{tabular}{|c|c|c|}
\hline & Pacific Coast & Juan de Fuca \\
\hline $\mathrm{n}$ & 4,394 & 3,151 \\
\hline $\begin{array}{l}\text { Temperature in } \\
\text { degrees Celsius }\end{array}$ & $7 / 26 / 2009$ & $7 / 29 / 2009$ \\
\hline Average & 11.0 & 10.2 \\
\hline Maximum & 16.2 & 13.7 \\
\hline Minimum & 9.7 & 7.5 \\
\hline StdDev & 1.0 & 1.0 \\
\hline $\begin{array}{l}\text { Salinity in practical } \\
\text { salinity units }\end{array}$ & $7 / 26 / 2009$ & $7 / 29 / 2009$ \\
\hline Average & $\mathrm{NaN}$ & 32 \\
\hline Maximum & $\mathrm{NaN}$ & 34 \\
\hline Minimum & $\mathrm{NaN}$ & 3.7 \\
\hline StdDev & $\mathrm{NaN}$ & 2.5 \\
\hline $\mathrm{pH}$ in $\mathrm{pH}$ units & $7 / 26 / 2009$ & $7 / 29 / 2009$ \\
\hline Maximum & $\mathrm{NaN}$ & 7.9 \\
\hline Minimum & $\mathrm{NaN}$ & 7.5 \\
\hline Median & $\mathrm{NaN}$ & 7.7 \\
\hline $\begin{array}{l}\text { Dissolved Oxygen in } \\
\text { milligrams per liter }\end{array}$ & $7 / 26 / 2009$ & $7 / 29 / 2009$ \\
\hline Average & 7.7 & 5.6 \\
\hline Maximum & 9.7 & 8.2 \\
\hline Minimum & 6.9 & 2.9 \\
\hline StdDev & 0.5 & 0.9 \\
\hline $\begin{array}{l}\text { Dissolved Oxygen } \\
\text { percent saturation }\end{array}$ & $7 / 26 / 2009$ & $7 / 29 / 2009$ \\
\hline Average & 86.5 & 61.9 \\
\hline Maximum & 103.9 & 90.1 \\
\hline Minimum & 75.5 & 29.9 \\
\hline StdDev & 5.9 & 10.2 \\
\hline $\begin{array}{l}\text { Turbidity in Formazin } \\
\text { Nephelometric Units }\end{array}$ & $7 / 26 / 2009$ & $7 / 29 / 2009$ \\
\hline Average & 6 & 1.3 \\
\hline Maximum & 85 & 83 \\
\hline Minimum & 0.0 & 0.0 \\
\hline StdDev & 9 & 6.6 \\
\hline
\end{tabular}




\section{Discussion}

The TJWQP provides detailed information on water-quality properties across a vast region of the Salish Sea at high temporal and spatial resolution [measurements ever 10 seconds, approximately every $22 \mathrm{~m} \mathrm{(75} \mathrm{ft)].} \mathrm{The} \mathrm{measurements} \mathrm{made} \mathrm{during} \mathrm{the} \mathrm{Tribal} \mathrm{Journey} \mathrm{in} \mathrm{middle} \mathrm{to} \mathrm{late} \mathrm{summer} \mathrm{are}$ important for understanding an ecologically stressful period when surface-water temperatures are high, freshwater runoff from streams is decreasing to summer low flow, and biological growth and decay in nearshore waters are high (Davenne and Masson, 2001). The 2008 TJWQP survey demonstrated that intensive water-quality monitoring across the Salish Sea could be accomplished and that landscape-scale and site-specific patterns in water quality could be identified. In 2009, with the strong commitment of Coast Salish canoe families, Tribal and First Nation natural-resource managers, educators, the USGS, and many other contributors, the TJWQP monitored water-quality conditions throughout the Salish Sea during an unusually warm period that included record high air temperatures. Water-quality results from the 2009 TJWQP thus have the potential to lend important insight into how conditions may respond to future climate change, including impacts to nearshore waters from predicted increases in summer air temperatures and reduced summer river runoff (Littell and others, 2009). The results presented in this report are useful to show spatial differences between conditions in the Salish Sea in 2008 and 2009. Additional results from depth profiling and mooring deployments conducted in 2009 will assist in characterizing changes in water quality with depth and through time, and they will be presented in a forthcoming report.

Some of the warmest days on record in the Pacific Northwest occurred during the 2009 Journey. Maximum July temperatures in the Olympia area reached $40^{\circ} \mathrm{C}$ (average $19^{\circ} \mathrm{C}$ ) and $39^{\circ} \mathrm{C}$ (average 21 ${ }^{\circ} \mathrm{C}$ ) in Seattle (National Oceanic and Atmospheric Administration, 2009), providing the TJWQP a glimpse of how the Salish Sea may respond to future predicted climate-change driven warming. Temperatures in the northern Salish Sea ranged from $30.0^{\circ} \mathrm{C}$ in Blaine to $34.4^{\circ} \mathrm{C}$ in Vancouver (Environment Canada, 2009). No precipitation was recorded by the traveling canoes from July 21 to August 4, 2009. Skies were mostly sunny with light wind conditions on the water.

In contrast to 2009, weather conditions for the Salish Sea region during the 2008 Tribal Journey were not as extreme during the month of July. The Fraser River valley experienced warm air temperatures between $23{ }^{\circ} \mathrm{C}$ and $27^{\circ} \mathrm{C}$ with calm winds. The southern Salish Sea region experienced cooler temperatures in the mornings, 12 to $14{ }^{\circ} \mathrm{C}$, warming into the afternoon to $20{ }^{\circ} \mathrm{C}$. The skies were sunny to partly cloudy during the two week period with light to breezy wind conditions on the water.

Our results show all of the basins but one monitored in both years had higher surface-water temperatures in 2009 than in 2008. The only exception was Juan de Fuca Basin, which was $1.1{ }^{\circ} \mathrm{C}$ lower in 2009 than in 2008. The lower temperatures in 2009 were likely due to much stronger offshore and much weaker southerly alongshore components of upwelling during and preceeding (one and two weeks prior to) our measurements in 2009 and 2008. The highest temperatures in 2009 were recorded in Hood Canal, South Puget Sound, and Squamish Basins (fig. 26). South Puget Sound Basin had the greatest difference in mean surface-water temperature between years and was $4.3^{\circ} \mathrm{C}$ warmer in 2009 than in 2008. Whidbey and Hood Canal Basins were $3.0^{\circ} \mathrm{C}$ and $2.2^{\circ} \mathrm{C}$ warmer in 2009 than in 2008 , respectively (fig. 28). Among the basins monitored in both years which cover much of the Salish Sea, we measured a mean temperature that was $0.7^{\circ} \mathrm{C}$ higher in 2009 than in 2008 . The only exception was Juan de Fuca Basin, which was 1.1 lower in 2009 than in 2008. The lower temperatures in 2009 were likely due to much stronger offshore and much weaker southerly alongshore components of upwelling during and proceeding (one and two weeks prior to) our measurement in 2009 and 2008 (DART upwelling Indices, 45N125W-West of La Push, Wash., http://www.cbr.washington.edu/dart/upwell_com.html). In 2009, only the Pacific Coast and Juan de 
Fuca met Washington State criteria for extraordinary average surface-water temperatures (table 14). San Juan, North, and South Central Puget Sound had excellent water-temperature levels, while South Puget Sound, Whidbey, Lower Fraser, and Squamish Basins all had good surface water average temperature. The Hood Canal Basin was the only one with fair surface-water-quality average temperature.

With the elevated air temperatures experienced throughout the region in the summer of 2009 driving warmer surface-water tempeatures, it was expected that corresponding dissolved-oxygen concentrations would be lower. At several locations, including the surface waters off shore of Elwha in Juan de Fuca Basin, dissolved oxygen in surface waters was at concentrations that are recognized by the USEPA and Environment Canada as being threatening to the survival of marine organisms. Though most basins exhibited warmer surface-water temperatures in the summer of 2009 compaired to 2008, the San Juan and Squamish Basins both had areas with dissolved-oxygen concentrations above $16.0 \mathrm{mg} / \mathrm{L}$ and corresponding percent-saturation levels above 200 percent.

There were observations of a noticeable increase in suspended algal blooms in areas of dissolvedoxygen supersaturation. The most striking algal bloom occurred in Squamish Basin and spanned a distance of more than $11 \mathrm{~km}$. The lowest concentrations of dissolved oxygen were observed in the Juan de Fuca Basin, resulting in a classification of good dissolved-oxygen water quality during the Tribal Journey, However, all other basins were excellent or extraordinary for dissolved oxygen during the 2009 survey (table 5). San Juan and Whidbey basins had higher average dissolved oxygen in 2009 than in 2008 (fig. 28). 
Table 14. Average temperature and dissolved-oxygen classifications in the Salish Sea, 2008 and 2009. Classifications are based on Washington State water quality criteria extraordinary, excellent, good, and fair quality aquatic life uses (table 4).

\begin{tabular}{|c|c|c|}
\hline Squamish & 2008 & 2009 \\
\hline Temperature & & Good \\
\hline Dissolved Oxygen & & Extraordinary \\
\hline Lower Fraser & 2008 & 2009 \\
\hline Temperature & & Good \\
\hline Dissolved Oxygen & & Extraordinary \\
\hline San Juan & 2008 & 2009 \\
\hline Temperature & Extraordinary & Excellent \\
\hline Dissolved Oxygen & Excellent & Extraordinary \\
\hline North Central Puget Sound & 2008 & 2009 \\
\hline Temperature & Extraordinary & Excellent \\
\hline Dissolved Oxygen & Extraordinary & Extraordinary \\
\hline Whidbey & 2008 & 2009 \\
\hline Temperature & Excellent & Good \\
\hline Dissolved Oxygen & Extraordinary & Extraordinary \\
\hline South Central Puget Sound & 2008 & 2009 \\
\hline Temperature & Excellent & Excellent \\
\hline Dissolved Oxygen & Extraordinary & Extraordinary \\
\hline Hood Canal & 2008 & 2009 \\
\hline Temperature & Good & Fair \\
\hline Dissolved Oxygen & Extraordinary & Excellent \\
\hline South Puget Sound & 2008 & 2009 \\
\hline Temperature & Excellent & Good \\
\hline Dissolved Oxygen & Extraordinary & \\
\hline Pacific Coast & 2008 & 2009 \\
\hline Temperature & & Extraordinary \\
\hline Dissolved Oxygen & & Extraordinary \\
\hline Juan de Fuca & 2008 & 2009 \\
\hline Temperature & Extraordinary & Extraordinary \\
\hline Dissolved Oxygen & Extraordinary & Good \\
\hline
\end{tabular}

\begin{tabular}{|l|l|}
\hline Extraordinary & \\
\hline Excellent & \\
\hline Good & \\
\hline Fair & \\
\hline
\end{tabular}



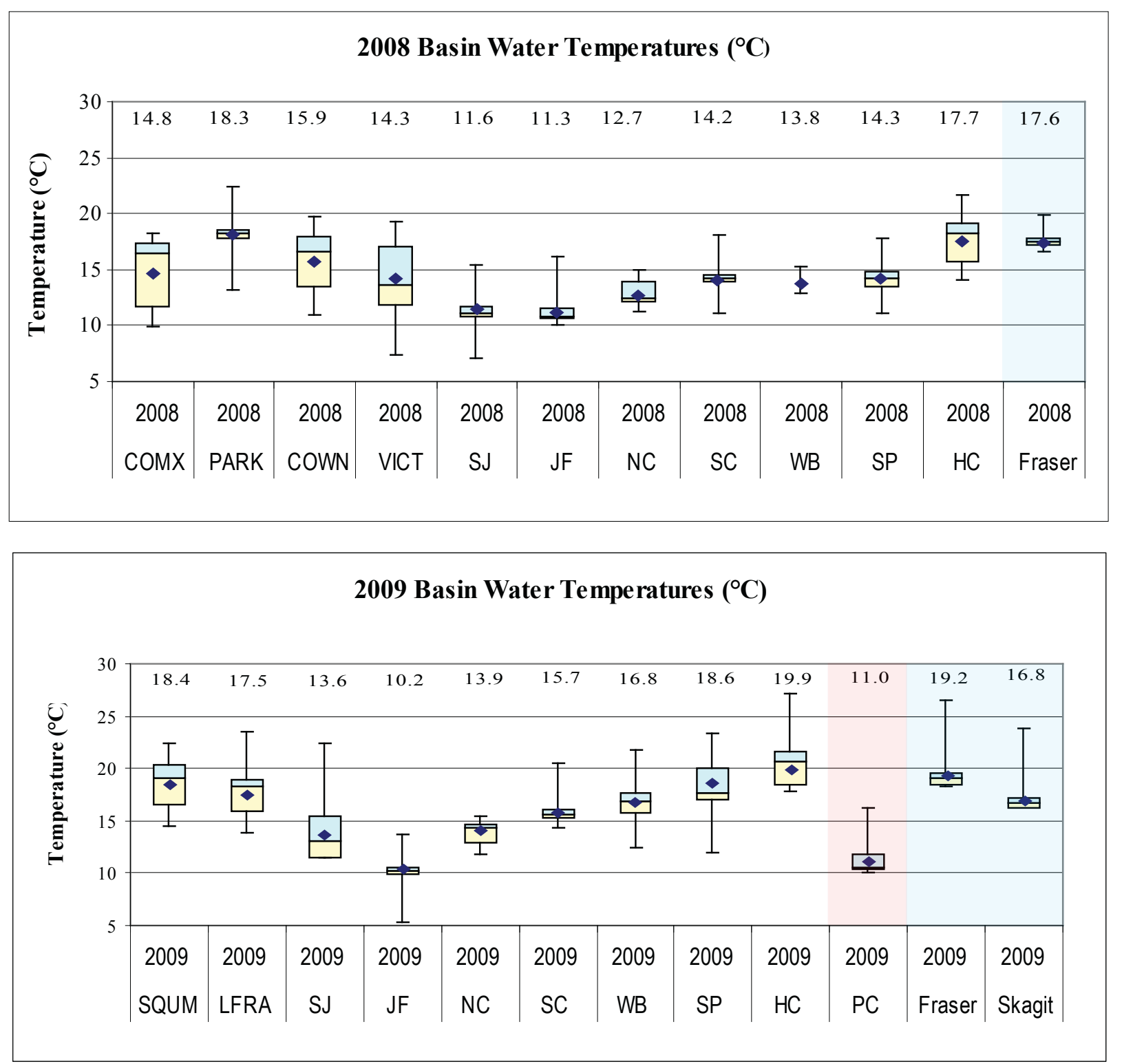

Figure 26. Surface-water temperature (in degrees Celsius) by basin in the Salish Sea, 2008 and 2009, for marine water bodies and fresh water. Basins are arranged from furthest north (left) to furthest south (right), followed by oceanic and fresh water inputs. Numbers above plots are the average temperature for each basin. 

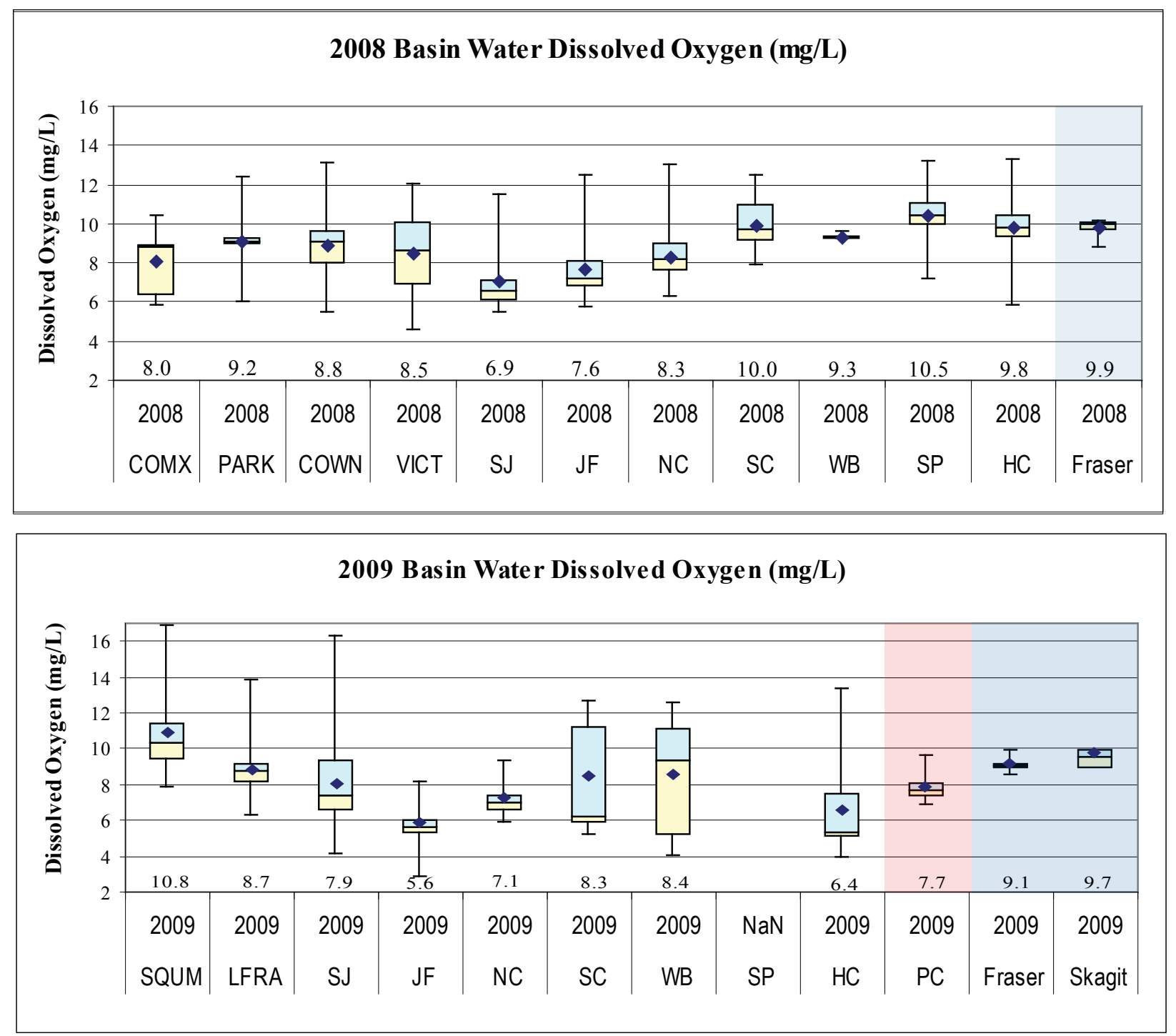

Figure 27. Dissolved-oxygen concentrations by basin in the Salish Sea, 2008 and 2009. Basins are arranged from furthest north (left) to furthest south (right), followed by oceanic and fresh water inputs to the Salish Sea. NaN indicates no data. 

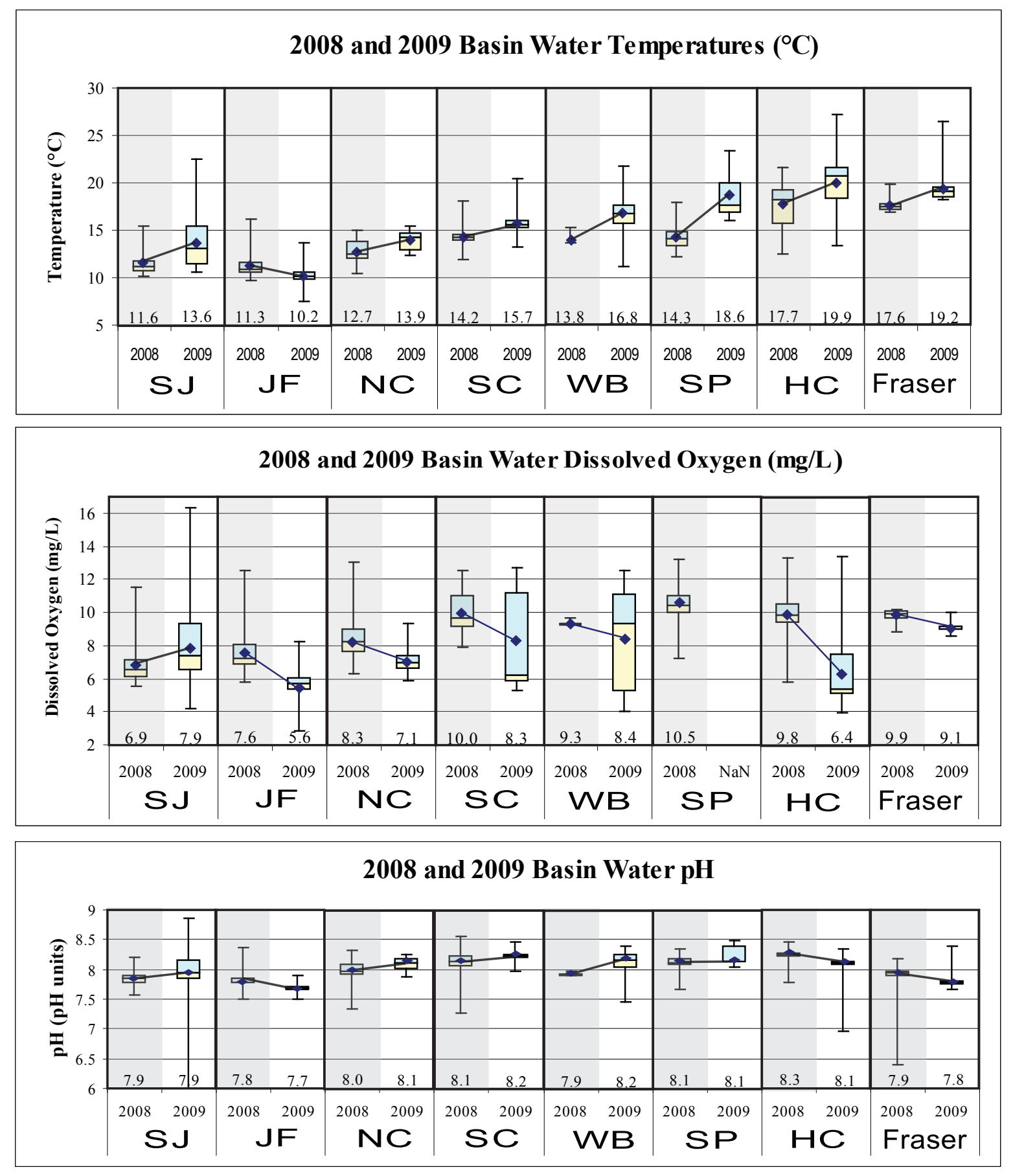

Figure 28. Temperature, dissolved oxygen, and pH by basin for the Salish Sea, 2008 and 2009. Basins are arranged from north (left) to south (right), followed by fresh water inputs from Fraser River.

Salinities in 2009 were greatest in the Juan de Fuca Basin owing to the close proximity and strongest influence of the Pacific Ocean relative to the other basins. Squamish Basin had the lowest average salinity of all the basins monitored. Squamish, Lower Fraser, and Whidbey Basins showed depressed salinity results related to the freshwater inputs from the Squamish, Fraser, and Skagit Rivers. 
The freshwater plume of the Skagit River was detected, through depressed salinity levels from surrounding areas, as far away as $12 \mathrm{~km}$ north through the Swinomish Channel from the delta.

There were more instances of $\mathrm{pH}$ criteria exceedances ( $\mathrm{pH}$ less than 6.5 or greater than 8.5 units) in 2009 than in 2008 (fig. 28). Squamish, San Juan, and Whidbey Basins all contained water masses with $\mathrm{pH}$ levels exceeding $8.5 \mathrm{pH}$ units. These exceedances seemed to be associated with algal blooms and locally elevated water temperatures. The San Juan Basin had the widest range of $\mathrm{pH}$ readings of all sites, possibly related to the active mixing and upwelling of oceanic waters entering through the Strait of Juan De Fuca. Instances of $\mathrm{pH}$ greater than 9.0 units also generally were associated with an oxygen super-saturation. Juan de Fuca and Hood Canal Basins pH levels that were lower in 2009 than in 2008 (fig. 28).

In 2009, Salish Sea surface waters generally were clear, with low turbidities across all of the basins. Local exceptions occurred within the algal blooms observed in the North (Howe Sound, Burrard Inlet) and South (Central and South Puget Sound Basins) Regions, where turbidity levels were elevated due to high biological productivity, and in the Fraser River, where suspended sediment produced high turbidities.

The elevated surface-water temperatures seen in 2009 may be related to the higher air temperatures occurring in 2009 and associated warming of surface waters in shallow areas associated with tidal flats and shallow embayments, particularly areas with sluggish circulation. In Samish Bay, Port Susan, Port Gamble, Lynch Cove in Hood Canal and South Puget Sound north of Squaxin Island, surface-water temperatures were much higher in the shallow waters than adjacent deeper waters (fig. 29, $A-E)$. Higher insolation and air temperatures would increase water temperatures, particularly in shallow areas with long water-residence times. In addition, increased heating of tidally exposed substrates may be important; during day-time low tides the sun heats up exposed mud and sand on emergent tide flats, which then warms overlying waters as incoming tides flood the flats. In areas of reduced circulation within these shallow embayments, the cooling effect of incoming waters may not have been sufficient to cool important habitats for juvenile fishes and invertebrates. For instance, water temperatures above 18 ${ }^{\circ} \mathrm{C}$ are known to affect adversely the feeding behavior and ultimate survival of the bull trout, a Department of Interior Trust species (Selong and others, 2001). Also of interest, the Fraser River Delta, with a constant flow of fresh water, warmed $2{ }^{\circ} \mathrm{C}$ as the river water mixed in the estuary (fig. $29 \mathrm{C}$ ). Adequate time-series data for shallow estuaries are sparse. Improving our understanding of the magnitude, spatial extent, and duration of warming in shallow regions of the Salish Sea will be critical to understanding their impact on sensitive species. 

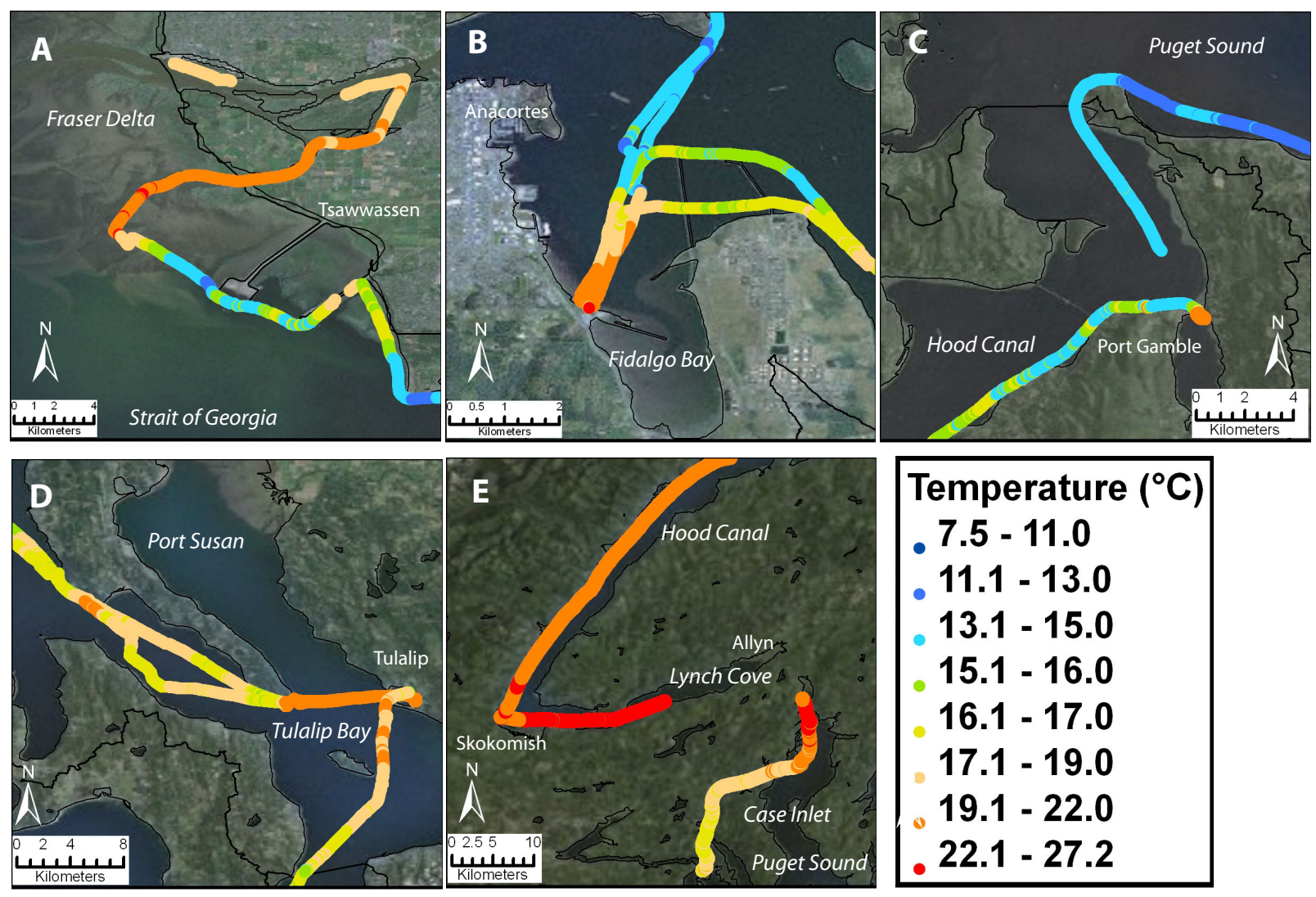

Figure 29. Elevated temperatures associated with shallow embayments monitored by the TJWQP. A, Samish Bay $B$, Port Susan C, Fraser River delta D, Port Gamble, Wash. E, South Puget Sound and Hood Canal.

In addition to identifying areas of water-quality impairment, the methods employed by this project collect sufficient quantitative data that may help define spatial gradients in water-quality and habitat conditions that may affect biota. Although examples of gradients in temperature and salinity near shallow embayments (fig. 29) and rivers (figs. 7, 13,19) clearly are influenced by freshwater inputs and warming of shallow waters as described above, striking and abrupt gradients in water quality also occur in other areas of the Salish Sea, particularly across boundaries between water masses with different properties. For example, at the mouth of East Sound at the south end of Orcas Island in the San Juan Islands, significant gradients were observed in temperature, $\mathrm{pH}$, and dissolved oxygen in association with a visible plume that extended for about $4 \mathrm{~km}$ and emanated from East Sound during the ebbing tide (fig. 30). A change of $3.3{ }^{\circ} \mathrm{C}$ occurred over a distance of $80 \mathrm{~m}$ along the west edge of the plume and a change of $4.2^{\circ} \mathrm{C}$ occurred across $100 \mathrm{~m}$ at the east edge of the plume. Changes of this magnitude are likely to be important to temperature-sensitive fishes, yet our understanding of such thresholds and impacts remains poor. Dissolved-oxygen concentrations also changed abruptly by $4.2 \mathrm{mg} / \mathrm{L}$ over a 250 $\mathrm{m}$ distance along the west plume edge, and by $6.7 \mathrm{mg} / \mathrm{L}$ along the eastern plume edge. Also along the eastern edge (within $0.2 \mathrm{~km}$ ), $\mathrm{pH}$ increased from 8.0 units in the surrounding waters to 8.7 units within the plume, which exceeds Washington State water-quality criteria. One of the strengths of the data obtained by the TJWQP is their ability to reveal these abrupt changes in water quality that occur over very short distances traditional water-quality monitoring frequently relies on repeated sampling at a single location which can only show changes with time. 


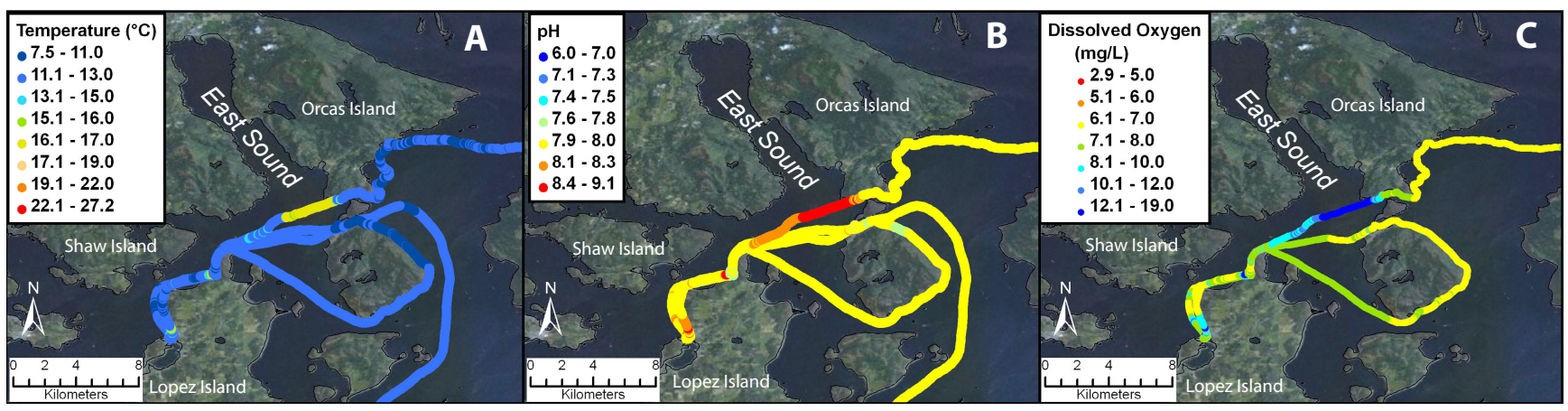

Figure 30. Water properties offshore of East Bay south of Orcas Island in the San Juan Islands. $A$ temperature in degrees Celsius, $B \mathrm{pH}$ in pH units, and $\mathrm{C}$ dissolved oxygen in milligrams per liter.

\section{Blending Science and Tradition}

Along the Tribal Journey, stories were shared between the elders, youth, the Skippers, and the Pullers. For some people the Tribal Journey is a time of healing, for others it is a way to reconnect with long lost relatives, and for all it is a way to maintain tradition. With the introduction of the TJWQP, there is an added dialogue, the status of the environment. The TJWQP has created an excellent opportunity for a concerned group of people, many of whom do not have science backgrounds, to play a key role in a research effort and to reaffirm the Coast Salish People's role as stewards of the environment.

With the success of the TJWQP, the Coast Salish People have made a significant contribution toward monitoring the waters of the Salish Sea. The outcome of the TJWQP will support the Coast Salish Nation's effort to address increasing environmental impacts. As the aboriginal inhabitants of the Salish Sea ecosystem, the Coast Salish People are responsible for the well being and health of their ecosystem and communities and perhaps through the TJWQP will be increasingly compelled to share their understanding and vision for improving the health of the Salish Sea. The Coast Salish People have an important leading role in helping to manage their communities today and into the future. The TJWQP acknowledges this role and encourages all Coast Salish People to participate actively and learn more about the conditions affecting their traditional territories across the Salish Sea.

Degradation of water quality has caused economic hardship impacting fishing and shellfish activities of the Coast Salish People. Culturally and economically, these are the core resources that define Coast Salish communities. Environmental issues affecting these resources thus affect the families and relatives on both sides of the border because this project provides Coast Salish with a science tool and because the information derived from the project can be shared with the world. We now have a unique opportunity to address these transboundary environmental issues across political boundaries. We know that environmental issues cannot be addressed individually or resolved with only local policy and actions, but that ecosystems need to be addressed at a larger scale, especially in the Salish Sea where tidal currents mix waters across political boundaries on a daily basis. The TJWQP is building a scientific foundation to gather data and to provide information for improved and informed policy. Data and findings will be disseminated through the Coast Salish Gathering, and information will be shared with Federal agencies and other interested parties. An open dialogue between the Coast Salish Gathering leadership and Federal representatives will strengthen the local effort to provide a safe and healthy home for Coast Salish People for today and tomorrow. This is the common goal on a local and regional basis for the Coast Salish Nation. 


\section{Future Directions}

The strength of the TJWQP lies in its ability to gather information over extensive areas at high spatial resolution, typically $\sim 22 \mathrm{~m}(\sim 75 \mathrm{ft})$. Collecting this data over multiple years, and hopefully decades, will aid in identifying trends and persistent impacts due to human activities and expected climate change. Planning is underway to secure funding and support to repeat the surveys during the 2010 Tribal Journey to Makah and into the future. As the project has grown scientifically, so have the relationships developed between the Coast Salish Canoe Families and TJWQP staff and new partners. For instance, planning is underway to develop an internship program through the Northwest Indian College and other local colleges and universities. The goal of this internship will be to broaden the impact of the TJWQP by providing additional environmental education to the Coast Salish communities and to provide opportunities for Coast Salish community members to participate in environmental monitoring within their own communities. These community-based internships will provide waterquality technician training to interested individuals and will broaden the scope of the existing study to include periods outside the time frame of the annual Tribal Journeys.

In addition to monitoring conducted from canoes in 2009, support boats were utilized to measure conductivity, temperature, and depth in vertical profiles by casting instruments from the surface to a maximum depth of $40 \mathrm{~m}$ and to collect water samples for analysis of phytoplankton and filtered nutrients. Results from the support-boat monitoring will provide information about nutrient patterns and their influence on food-web dynamics throughout the Salish Sea. Analysis of these data will be completed in 2010. In addition, four moored buoys with YSI sondes, temperature sensors throughout the water column, and water-level loggers at their base were deployed at Nisqually, Suquamish, Samish, and Nanaimo. Instruments on the moorings recorded water-quality physical properties and water levels continuously at 10 minute intervals for a three month period between July and September of 2009. Buoy data provide additional information on the temporal variability in water quality due to tidal mixing, daily heating and cooling, and variability associated with winds, upwelling, and river flow. Results of the support-boat and mooring-based monitoring activities will be synthesized in a subsequent report.

The water-quality information collected by the TJWQP is essential for the Coast Salish Nations to develop policy and to implement resource management in the Salish Sea ecosystem. It is the ultimate goal of the TJWQP coordinators that the TJWQP becomes a sustainable Coast Salish project and that Coast Salish build the capacity to administer and expand the project to suit their needs. Ideally, members of Canoe Families from around the Salish Sea will take the TJWQP forward for the greater good of the Coast Salish People.

\section{Acknowledgments}

The 2009 TJWQP was funded by the Northwest Straits Commission, the Swinomish Tribe, Environment Canada, and the USGS and supported by Coast Salish Chiefs, Chairmen, Elders, and Canoe Skippers, the USEPA, Environment Canada, and Parks Canada. We are grateful to the Squaxin Island Tribe, Homalco Nation, Sto:lo People, Squamish Nation, Songhees Nation, Blue Heron Canoe Club, and the Swinomish Canoe Families and are especially thankful for the dedicated efforts of the water-quality technicians who supported them. Thank you to the Northwest Straits Commission for the use of the GPS units and initial support. Thank you to Jude Apple for all of your advice and late night efforts. We would also like to thank Elissa Fjellman and Eric Haskins of the Swinomish GIS team for all of their help. We thank Ray Julich and Andrew Stevens of USGS for technical assistance in data visualization. Paul Dorn of Suquamish Tribe was of great assistance with monitoring at the final landing at Suquamish. Thank you dedicated technicians Tiffany Hoyopatubbi, Clinton Charlie, Carol Reiss, Nick Pinel, and Chris Curran. Last but not least we would like to thank Jennifer LaVista and Susan 
Marcus for all of their communications assistance and the efforts of Richard Wagner and Dan Hoover of the USGS for their thorough technical review of this report.

\section{References Cited}

Akin, S.K., Grossman, E.E., Lekanof, D., O’Hara, C., 2009, Coast Salish and U.S. Geological Survey: Tribal Journey water quality project, Coast Salish Gathering Report 2009-001, 58 p. [last accessed March 1, 2010, at http://walrus.wr.usgs.gov/reports/reprints/TJWQP.pdf].

British Columbia, 2007, Watershed atlas watershed codes for British Columbia, Canada [last accessed November 3, 2009, at http://www.env.gov.bc.ca/fish/watershed atlas maps/watershed code/wsg/index.html].

Coast Salish Gathering, 2008, Coast Salish gathering conference program 2008 [last accessed March 1, 2010, at http://www.coastsalishgathering.com/01gathering/proceedings.shtml].

Davenne, E., and Masson, D., 2001, Water properties in the Straits of Georgia and Juan de Fuca: Canada Department of Fisheries and Oceans [http://www.pac.dfompo.gc.ca/science/oceans/cotesud-southcoast/JdFG_e.pdf].

Environment Canada, 2000, Water quality trends in selected British Columbia water bodies, 2000 [last accessed May 7, 2008: http://www.env.gov.bc.ca/wat/wq/trendsWQS/regions.html].

Environment Canada, 2009, Discharge and water temperature measurements for the Fraser River at Hope (08MF005), British Columbia [last accessed November 28, 2009 at http://scitech.pyr.ec.gc.ca/waterweb/fullgraph.asp].

Environment Canada, 2009b, Monthly climate statistics for July to August 2009 [last accessed December 10, 2009 at http://www.climate.weatheroffice.ec.gc.ca/climateData/canada_e.html].

Fraser, D.A., Gaydos, J.K., Karlsen, E., and Rylko, M.S., 2006, Collaborative science, policy development and program implementation in the transboundary Georgia Basin/Puget Sound Ecosystem: Environmental Monitoring and Assessment 113, p. 49-69.

Littell, J.S., M. McGuire Elsner, L.C. Whitely Binder, and A.K. Snover, eds., 2009, The Washington Climate Change Impacts Assessment: Evaluating Washington's Future in a Changing Climate Executive Summary. in The Washington Climate Change Impacts Assessment: Evaluating Washington's Future in a Changing Climate, Climate Impacts Group, University of Washington, Seattle, Washington [last accessed on April 13, 2010, at http://www.cses.washington.edu/db/pdf/wacciaexecsummary638.pdf].

National Oceanic and Atmospheric Administration, 2009, National Weather Service monthly statistic query [last accessed on December 10, 2009, at http://www.weather.gov/climate/xmacis.php?wfo=sew].

National Oceanic and Atmospheric Administration, 2009b Friday Harbor tides and currents [last accessed on September 21, 2009, at http://tidesandcurrents.noaa.gov/geo.shtml?location=9449880].

Puget Sound Partnership, 2008, Action Agenda [last accessed on December 10, 2008, at http://www.psp.wa.gov/aa_action_agenda.php].

SeaDoc, 2008, "Salish Sea Facts" The SeaDoc Society, 2008 [last accessed on December 10, 2008 at http://www.seadocsociety.org/Salish-Sea-Facts].

Selong, J.H., T. McMahon, A.V. Zale, F.T. Barrows, 2001, Effect of Temperature on Growth and Survival of Bull Trout, with Application of an Improved Method for Determining Thermal Tolerance in Fishes. Transactions of the American Fisheries Society 2001; 130: 1026-1037. 
Shipman, H., 2008, A Geomorphic classification of Puget Sound nearshore landforms. Puget Sound Nearshore Partnership Report No. 2008-01. Published by Seattle District, U.S. Army Corps of Engineers, Seattle, Washington.

Washington Administrative Code, 2006, Washington State Department of Ecology marine water designated uses and criteria WAC Title 173-201A-210 [last accessed March 3, 2008, at http://apps.leg.wa.gov/wac/default.aspx?cite=173-201A-210].

Washington Sea Grant Program, 2000, Draft: Northwest Straits Overview A Science Gap Report [last accessed December 10, 2008 at http://www.wsg.washington.edu/communications/online/gap.pdf].

Wilde, F.D., ed., 2005, Field Measurements: U.S. Geological Survey Techniques of Water-Resources Investigations, book 9, chap. A6 [last accessed December 2, 2008 at http://pubs.water.usgs.gov/twri9A/].

United States Environmental Protection Agency, 2008, Puget Sound Georgia Basin Ecosystem Indicators: United States Environmental Protection Agency [http://www.epa.gov/region10/psgb/indicators/].

United States Geological Survey, 2009, USGS Surface-Water Data for Washington [last accessed December 11, 2009 at http://wdr.water.usgs.gov/wy2009/pdfs/12200500.2009.pdf]. 


\section{Appendixes}

Appendix I: YSI 6920 V2-2 Sensor specifications including units, range, resolution, and accuracy.

\begin{tabular}{|c|c|c|c|c|}
\hline YSI Sensor & Units & Range & Resolution & Accuracy \\
\hline \multirow{2}{*}{$\begin{array}{c}\text { ROX Optical } \\
\text { Dissolved Oxygen }\end{array}$} & $\mathrm{mg} / \mathrm{L}$ & 0 to $50 \mathrm{mg} / \mathrm{L}$ & $0.01 \mathrm{mg} / \mathrm{L}$ & $\begin{array}{l}0 \text { to } 20 \mathrm{mg} / \mathrm{L}: \pm 0.1 \mathrm{mg} / \mathrm{L} \text { or } \\
1 \% \text { of reading }\end{array}$ \\
\hline & $\begin{array}{c}\% \\
\text { Saturation }\end{array}$ & 0 to $500 \%$ & $0.10 \%$ & $\begin{array}{l}0 \text { to } 200 \%: \pm 1 \% \text { or } 1 \% \text { of } \\
\text { air saturation }\end{array}$ \\
\hline \multirow{2}{*}{$\begin{array}{l}\text { Dissolved Oxygen } \\
6562 \text { Rapid Pulse }\end{array}$} & $\mathrm{mg} / \mathrm{L}$ & 0 to $50 \mathrm{mg} / \mathrm{L}$ & $0.01 \mathrm{mg} / \mathrm{L}$ & $\begin{array}{l}0 \text { to } 20 \mathrm{mg} / \mathrm{L}: \pm 0.2 \mathrm{mg} / \mathrm{L} \text { or } \\
2 \% \text { of reading }\end{array}$ \\
\hline & $\begin{array}{c}\% \\
\text { Saturation }\end{array}$ & 0 to $500 \%$ & $0.10 \%$ & $\begin{array}{l}0 \text { to } 200 \%: \pm 2 \% \text { or } 1 \% \text { of } \\
\text { air saturation }\end{array}$ \\
\hline $\begin{array}{l}\text { Turbidity } 6136 \\
\text { Sensor }\end{array}$ & $\mathrm{FNU}_{1}$ & $\begin{array}{l}0 \text { to } 1,000 \\
\text { FNU }\end{array}$ & $0.1 \mathrm{FNU}$ & $\begin{array}{l} \pm 2 \% \text { of reading or } 0.3 \\
\text { FNU, whichever is greater }\end{array}$ \\
\hline $\begin{array}{l}\text { Conductivity } 6560 \\
\text { Sensor }\end{array}$ & $\mathrm{mS} / \mathrm{cm}$ & $\begin{array}{l}0 \text { to } 100 \\
\mathrm{mS} / \mathrm{cm}\end{array}$ & $\begin{array}{c}0.001 \text { to } 0.1 \\
\mathrm{mS} / \mathrm{cm}\end{array}$ & $\begin{array}{l} \pm 0.5 \% \text { of reading }+0.001 \\
\mathrm{mS} / \mathrm{cm}\end{array}$ \\
\hline Salinity & ppt & 0 to $70 \mathrm{ppt}$ & $0.01 \mathrm{ppt}$ & $\begin{array}{l} \pm 1 \% \text { of reading or } 0.1 \mathrm{ppt} \\
\text { whichever is greater }\end{array}$ \\
\hline $\begin{array}{l}\text { Temperature } 6560 \\
\text { Sensor }\end{array}$ & ${ }^{\circ} \mathrm{C}$ & -5 to $+50^{\circ} \mathrm{C}$ & $0.01^{\circ} \mathrm{C}$ & $\pm 0.15^{\circ} \mathrm{C}$ \\
\hline pH 6561 Sensor & pH units & 0 to 14 units & 0.01 units & \pm 0.2 units \\
\hline ORP & $\mathrm{mV}$ & $\begin{array}{c}-999 \text { to }+999 \\
m V\end{array}$ & $0.1 \mathrm{mV}$ & $\pm 20 \mathrm{mV}$ \\
\hline Chlorophyll 6025 & $\mu g / L$ & $\begin{array}{c}\sim 0 \text { to } 400 \\
\mu \mathrm{g} / \mathrm{L}\end{array}$ & $\sim 0.1$ & $0.1 \mu \mathrm{g} / \mathrm{L} \mathrm{Chl}$ \\
\hline Depth - Shallow & $\mathrm{m}$ & 0 to $9.1 \mathrm{~m}$ & $0.001 \mathrm{~m}$ & $\pm 0.02 \mathrm{~m}$ \\
\hline
\end{tabular}

Units include milligrams per liter (mg/L), percent (\%), Formazin Nephelometric Units (FNU), millisemans per centimeter $(\mathrm{mS} / \mathrm{cm})$, parts per thousand $(\mathrm{ppt})$, degrees Celsius $\left({ }^{\circ} \mathrm{C}\right), \mathrm{pH}$ standard units, millivolts $(\mathrm{mV})$, and meters $(\mathrm{m})$

1. The United States Geological Survey methods for reporting turbidity data collected with near-infrared turbidimeters following ISO 7027 protocols is reported as Formazin Nephelometric Units (FNU). More information can be found in the USGS National Field Manual

(http://water.usgs.gov/owq/FieldManual/Chapter6/6.8.pdf). 
Appendix II: Calibration and Audit Log recording the accuracy of conductivity, pH, turbidity, and dissolved oxygen.

Failed audits are highlighted in red.

[Units include milligrams per liter $(\mathrm{mg} / \mathrm{L})$, percent $(\%)$, Formazin Nephelometric Units $(\mathrm{FNU})$, millisemans per centimeter $(\mathrm{mS} / \mathrm{cm})$, degrees Celsius $\left.\left({ }^{\circ} \mathrm{C}\right).\right]$

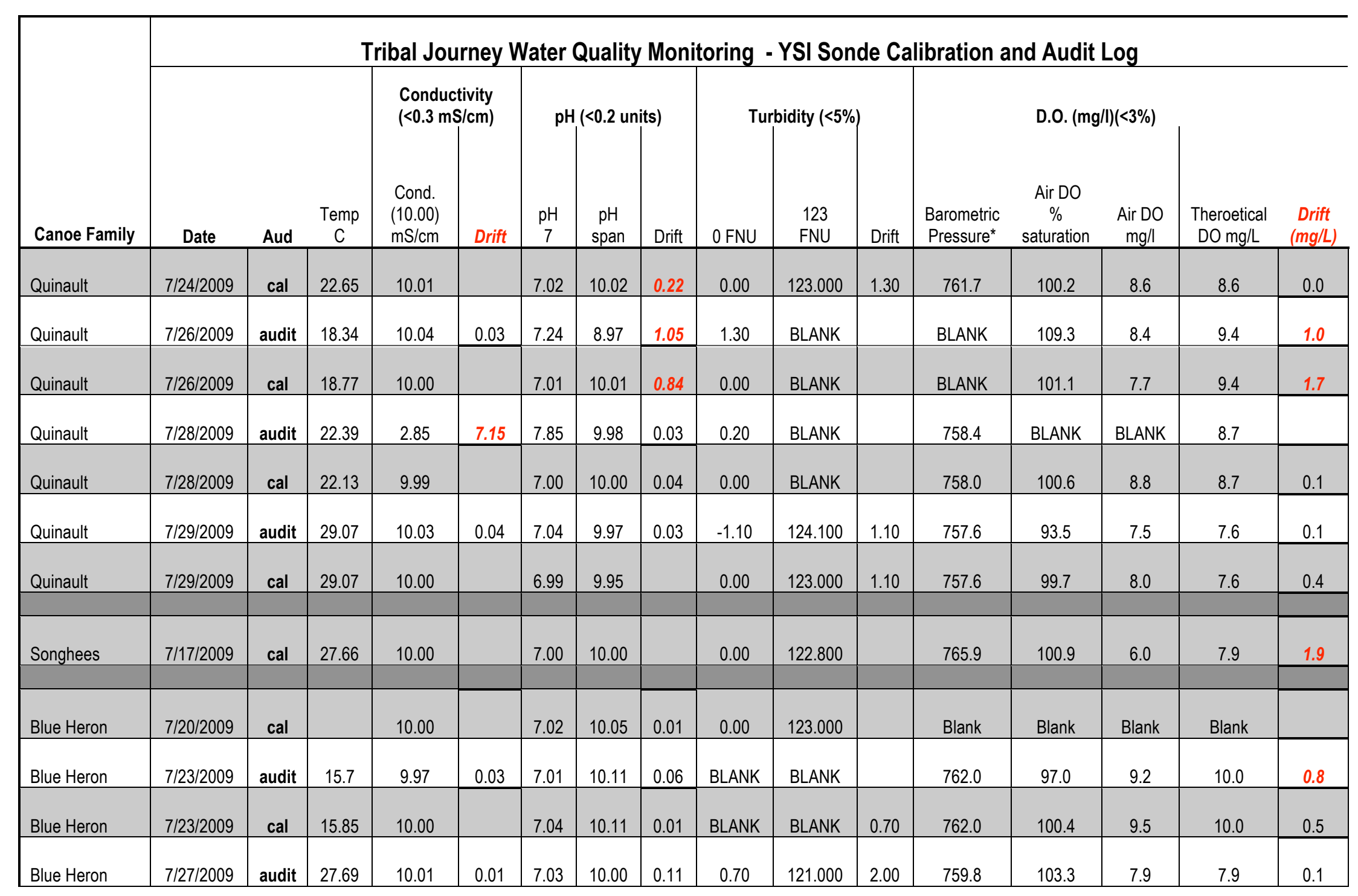


Appendix II: Calibration and Audit Log recording the accuracy of conductivity, pH, turbidity, and dissolved oxygen.

Failed audits are highlighted in red.

[Units include milligrams per liter (mg/L), percent (\%), Formazin Nephelometric Units $(\mathrm{FNU})_{1}$, millisemans per centimeter $(\mathrm{mS} / \mathrm{cm})$, degrees Celsius $\left({ }^{\circ} \mathrm{C}\right)$.]

\begin{tabular}{|c|c|c|c|c|c|c|c|c|c|c|c|c|c|c|c|c|}
\hline \multirow[b]{3}{*}{$\begin{array}{l}\text { Canoe } \\
\text { Family }\end{array}$} & \multicolumn{16}{|c|}{ Tribal Journey Water Quality Monitoring - YSI Sonde Calibration and Audit Log } \\
\hline & & & & $\begin{array}{l}\text { Condu } \\
(<0.3 \mathrm{~m}\end{array}$ & $\begin{array}{l}\text { ivity } \\
\text { /cm) }\end{array}$ & & $<0.2$ un & & & bidity $(<5 \%$ & & & D.O. $(\mathrm{mg} / \mathrm{l})$ & $<3 \%)$ & & \\
\hline & Date & Aud & $\begin{array}{c}\text { Temp } \\
\text { C }\end{array}$ & $\begin{array}{l}(10.00) \\
\mathrm{mS} / \mathrm{cm}\end{array}$ & Drift & $\begin{array}{c}\mathrm{pH} \\
7 \\
\end{array}$ & $\begin{array}{c}\mathrm{pH} \\
\text { span }\end{array}$ & Drift & $\begin{array}{c}0 \\
\text { FNU }\end{array}$ & $\begin{array}{l}123 \\
\text { FNU }\end{array}$ & Drift & $\begin{array}{l}\text { Barometric } \\
\text { Pressure }^{*}\end{array}$ & $\begin{array}{c}\% \\
\text { saturation }\end{array}$ & $\begin{array}{c}\mathrm{DO} \\
\mathrm{mg} / \mathrm{l}\end{array}$ & $\begin{array}{l}\text { Theroetical } \\
\text { DO mg/L }\end{array}$ & $\begin{array}{c}\text { Drift } \\
(\mathrm{mg} / \mathrm{L})\end{array}$ \\
\hline Swinomish & $7 / 27 / 2009$ & cal & 27.69 & 10.00 & & 7.00 & 10.00 & 0.03 & 0.00 & 123.000 & 0.10 & 759.3 & 100.0 & 7.6 & 7.9 & 0.3 \\
\hline Swinomish & $7 / 29 / 2009$ & audit & 21.11 & 9.92 & 0.08 & 7.03 & 10.04 & 0.04 & -0.10 & BLANK & & 760.5 & 99.6 & 8.4 & 8.5 & 0.1 \\
\hline Swinomish & $7 / 29 / 2009$ & cal & 21.11 & 10.00 & & 7.00 & 10.00 & 0.00 & 0.00 & BLANK & 0.40 & 760.0 & 100.0 & 8.4 & 8.5 & 0.1 \\
\hline Swinomish & $7 / 29 / 2009$ & audit & 25.31 & 9.97 & 0.03 & 7.00 & 9.98 & 0.02 & -0.40 & BLANK & & 756.1 & 101.8 & 8.4 & 8.2 & 0.2 \\
\hline Swinomish & 7/29/2009 & cal & 25.31 & 10.00 & & 7.00 & 10.00 & 0.02 & 0.00 & BLANK & 0.20 & 756.2 & 99.4 & 8.2 & 8.2 & 0.0 \\
\hline Swinomish & $7 / 31 / 2009$ & audit & 24.76 & 10.04 & 0.04 & 6.98 & 10.02 & 0.02 & 0.20 & BLANK & & 759.5 & 101.4 & 8.8 & 8.3 & 0.5 \\
\hline Swinomish & $7 / 31 / 2009$ & cal & 24.76 & 10.00 & & 7.00 & 10.00 & 0.04 & 0.00 & BLANK & 0.80 & 759.5 & 99.9 & 8.7 & 8.3 & 0.4 \\
\hline Swinomish & $8 / 2 / 2009$ & audit & 23.73 & 10.07 & 0.07 & 7.04 & 10.02 & 0.02 & -0.80 & 123.300 & 0.30 & 761.5 & 99.5 & 8.4 & 8.5 & 0.1 \\
\hline Swinomish & $8 / 2 / 2009$ & cal & 23.7 & 10.00 & & 7.01 & 10.03 & 0.06 & 0.00 & 123.000 & 0.40 & 761.5 & 100.4 & 8.4 & 8.5 & 0.1 \\
\hline Swinomish & $8 / 4 / 2009$ & audit & 18.84 & 9.98 & 0.03 & 6.95 & 10.08 & 0.05 & 0.40 & 123.600 & 0.60 & 762.1 & 100.7 & 9.2 & 9.3 & 0.1 \\
\hline Swinomish & $8 / 4 / 2009$ & cal & 18.84 & 10.00 & & 7.03 & 10.08 & & 0.00 & 123.000 & & 762.1 & 100.2 & 9.2 & 9.3 & 0.1 \\
\hline
\end{tabular}


Appendix II: Calibration and Audit Log recording the accuracy of conductivity, pH, turbidity, and dissolved oxygen.

Failed audits are highlighted in red.

[Units include milligrams per liter $(\mathrm{mg} / \mathrm{L})$, percent $(\%)$, Formazin Nephelometric Units $(\mathrm{FNU})_{1}$, millisemans per centimeter $(\mathrm{mS} / \mathrm{cm})$, degrees Celsius $\left({ }^{\circ} \mathrm{C}\right)$.]

\begin{tabular}{|c|c|c|c|c|c|c|c|c|c|c|c|c|c|c|c|c|}
\hline \multirow[b]{3}{*}{$\begin{array}{l}\text { Canoe } \\
\text { Family }\end{array}$} & \multicolumn{16}{|c|}{ Tribal Journey Water Quality Monitoring - YSI Sonde Calibration and Audit Log } \\
\hline & \multirow[b]{2}{*}{ Date } & \multirow[b]{2}{*}{ Aud } & \multirow[b]{2}{*}{$\begin{array}{l}\text { Temp } \\
\mathrm{C}\end{array}$} & \multirow{2}{*}{\multicolumn{2}{|c|}{$\begin{array}{c}\text { Conductivity }(<0.3 \\
\mathrm{mS} / \mathrm{cm}) \\
\begin{array}{c|}\text { Cond. (10.00) } \\
\mathrm{mS} / \mathrm{cm}\end{array} \\
\end{array}$}} & \multicolumn{3}{|c|}{$\mathrm{pH}(<0.2$ units) } & \multicolumn{3}{|c|}{ Turbidity $(<5 \%)$} & \multicolumn{3}{|c|}{ D.O. $(\mathrm{mg} / \mathrm{l})(<3 \%)$} & \multirow[b]{2}{*}{$\begin{array}{l}\text { Theroetical } \\
\text { DO mg/L }\end{array}$} & \multirow[b]{2}{*}{$\begin{array}{r}\text { Drift } \\
(\mathrm{mg} / \mathrm{L}\end{array}$} \\
\hline & & & & & & $\mathrm{pH} 7$ & $\begin{array}{c}\mathrm{pH} \\
\text { span }\end{array}$ & Drift & $\begin{array}{c}0 \\
\text { FNU }\end{array}$ & $\begin{array}{l}123 \\
\text { FNU }\end{array}$ & Drift & $\begin{array}{l}\text { Barometric } \\
\text { Pressure }^{*}\end{array}$ & $\begin{array}{l}\text { Air DO \% } \\
\text { saturation }\end{array}$ & $\begin{array}{c}\text { Air DO } \\
\mathrm{mg} / \mathrm{l}\end{array}$ & & \\
\hline Squamish & $7 / 21 / 2009$ & cal & 27 & 10.00 & & 7.00 & 9.98 & 0.15 & 0.00 & 123.000 & 3.10 & 762.3 & 100.3 & 8.2 & 7.9 & 0.3 \\
\hline Squamish & $7 / 22 / 2009$ & audit & 21.95 & 10.09 & 0.09 & 7.15 & 9.98 & 0.00 & 3.10 & BLANK & & 761.1 & 100.7 & 9.1 & 8.7 & 0.4 \\
\hline Squamish & $7 / 22 / 2009$ & cal & 21.95 & 10.00 & & 7.00 & 10.00 & 0.00 & 0.40 & BLANK & 0.10 & 761.1 & 100.2 & 9.1 & 9.1 & 0.0 \\
\hline Squamish & $7 / 23 / 2009$ & audit & 18.7 & 5.35 & 4.65 & 7.00 & 10.04 & 0.04 & 0.50 & BLANK & & 762.8 & 103.4 & 9.7 & 9.4 & 0.3 \\
\hline Squamish & $7 / 23 / 2009$ & cal & 18.7 & 10.00 & & 7.00 & 10.00 & 0.04 & 0.00 & BLANK & 0.00 & 762.8 & 100.3 & 9.5 & 9.4 & 0.1 \\
\hline Squamish & $7 / 24 / 2009$ & audit & 19.87 & 9.73 & 0.27 & 6.96 & 9.99 & 0.01 & 0.00 & BLANK & & 761.7 & 98.0 & 9.1 & 9.2 & 0.1 \\
\hline Squamish & $7 / 24 / 2009$ & cal & 19.88 & 10.00 & & 7.00 & 10.00 & 0.00 & 0.00 & BLANK & 0.50 & 761.7 & 100.2 & 9.3 & 9.2 & 0.1 \\
\hline Squamish & $7 / 25 / 2009$ & audit & 21.06 & 10.32 & 0.32 & 7.00 & 10.02 & 0.02 & 0.50 & BLANK & & 762.2 & 90.6 & 8.0 & 8.9 & 0.9 \\
\hline Squamish & $7 / 25 / 2009$ & $\mathrm{cal}$ & 21.07 & 10.00 & & 7.00 & 10.00 & 0.06 & 0.00 & BLANK & 1.99 & 762.3 & 100.2 & 8.9 & 8.9 & 0.1 \\
\hline Squamish & $7 / 27 / 2009$ & audit & 27.7 & 11.50 & 1.50 & 6.94 & 9.96 & 0.04 & -1.99 & 119.400 & 3.60 & 759.3 & 81.0 & 6.5 & 8.1 & 1.6 \\
\hline Squamish & $7 / 27 / 2009$ & cal & 27.7 & BLANK & & 7.00 & 10.00 & 0.14 & 0.00 & 123.000 & 0.50 & 759.3 & 99.8 & 8.0 & 8.1 & 0.1 \\
\hline Squamish & $7 / 29 / 2009$ & audit & 25.31 & 9.71 & 0.29 & 7.14 & 9.96 & 0.04 & 0.50 & BLANK & & 755.9 & 106.5 & 8.7 & 8.3 & 0.5 \\
\hline Squamish & $7 / 29 / 2009$ & cal & 25.3 & 9.99 & & 7.00 & 10.00 & 0.10 & 0.00 & BLANK & 0.20 & 755.9 & 99.4 & 8.2 & 8.3 & 0.1 \\
\hline Squamish & $7 / 30 / 2009$ & audit & 21.62 & 9.87 & 0.12 & 6.90 & 10.08 & 0.08 & -0.20 & BLANK & & 757.6 & 113.1 & 9.7 & 8.7 & 1.0 \\
\hline Squamish & $7 / 30 / 2009$ & cal & 21.62 & 10.00 & & 7.00 & 10.05 & 0.07 & 0.00 & BLANK & 0.70 & 757.6 & 99.5 & 8.5 & 8.7 & 0.2 \\
\hline Squamish & $7 / 31 / 2009$ & audit & 23.02 & 9.96 & 0.04 & 6.93 & 10.06 & 0.01 & 0.70 & BLANK & & 761.4 & 81.6 & 7.0 & 8.6 & 1.6 \\
\hline Squamish & $7 / 31 / 2009$ & cal & 23.02 & 10.01 & & 7.00 & 10.00 & & 0.00 & BLANK & & 761.2 & 100.0 & 8.5 & 8.6 & 0.1 \\
\hline
\end{tabular}


Appendix II: Calibration and Audit Log recording the accuracy of conductivity, pH, turbidity, and dissolved oxygen. Failed audits are highlighted in red.

[Units include milligrams per liter (mg/L), percent (\%), Formazin Nephelometric Units $(\mathrm{FNU})_{1}$, millisemans per centimeter $(\mathrm{mS} / \mathrm{cm})$, degrees Celsius $\left({ }^{\circ} \mathrm{C}\right)$.]

\begin{tabular}{|c|c|c|c|c|c|c|c|c|c|c|c|c|c|c|c|c|}
\hline \multirow[b]{3}{*}{ Canoe Family } & \multicolumn{16}{|c|}{ Tribal Journey Water Quality Monitoring - YSI Sonde Calibration and Audit Log } \\
\hline & & & & $\begin{array}{l}\text { Condu } \\
(<0.3 \mathrm{~m}\end{array}$ & $\begin{array}{l}\text { ivity } \\
\text { (cm) }\end{array}$ & & $<0.2$ un & & & bidity $(<$ & & & D.O. (mg/l & $(<3 \%)$ & & \\
\hline & Date & Aud & $\begin{array}{c}\text { Temp } \\
\text { C }\end{array}$ & $\begin{array}{l}(10.00) \\
\mathrm{mS} / \mathrm{cm}\end{array}$ & Drift & $\mathrm{pH} 7$ & $\begin{array}{c}\mathrm{pH} \\
\text { span }\end{array}$ & Drift & $0 \mathrm{FNU}$ & $\begin{array}{c}123 \\
\text { FNU }\end{array}$ & Drift & $\begin{array}{l}\text { Barometric } \\
\text { Pressure* }\end{array}$ & $\begin{array}{c}\% \\
\text { saturation }\end{array}$ & $\begin{array}{c}\mathrm{DO} \\
\mathrm{mg} / \mathrm{l}\end{array}$ & $\begin{array}{c}\text { Theroetical } \\
\text { DO mg/L }\end{array}$ & $\begin{array}{c}\text { Drift } \\
\text { (mg/L) }\end{array}$ \\
\hline Squaxin Island & $7 / 27 / 2009$ & audit & 30.37 & 10.12 & 0.12 & 7.06 & 9.96 & 0.01 & 0.40 & BLANK & & 762.7 & 91.3 & 6.9 & 7.6 & 0.7 \\
\hline Squaxin Island & $7 / 27 / 2009$ & cal & 30.37 & 10.00 & & 6.99 & 9.95 & 0.00 & 0.00 & BLANK & 0.50 & 762.7 & 100.3 & 7.6 & 7.6 & 0.0 \\
\hline Squaxin Island & $7 / 28 / 2009$ & audit & 30.22 & 9.99 & 0.01 & 6.99 & 10.01 & 0.06 & -0.50 & BLANK & & 759.4 & 86.2 & 5.4 & 6.4 & 1.0 \\
\hline Squaxin Island & $7 / 28 / 2009$ & cal & 30.22 & 10.01 & & 6.99 & 9.96 & 0.05 & 0.00 & BLANK & 0.20 & 759.4 & 98.2 & 6.4 & 6.4 & 0.0 \\
\hline Squaxin Island & $7 / 31 / 2009$ & cal & 20.14 & 10.00 & & 7.02 & 10.05 & 0.11 & 0.00 & 123.000 & 0.20 & 760.3 & 99.6 & 8.5 & 9.1 & 0.6 \\
\hline Squaxin Island & $8 / 1 / 2009$ & audit & 23.48 & 9.94 & 0.06 & 6.91 & 9.99 & 0.06 & -0.20 & 120.000 & 3.00 & 748.6 & 103.2 & 8.6 & 8.5 & 0.1 \\
\hline Squaxin Island & & cal & Blank & Blank & & Blank & Blank & & Blank & Blank & & Blank & Blank & Blank & Blank & \\
\hline Squaxin Island & $8 / 4 / 2009$ & audit & 18.15 & 10.09 & 0.09 & 7.06 & 10.09 & 0.04 & 122.10 & BLANK & 122.10 & 761.7 & 103.0 & 9.4 & 9.5 & 0.1 \\
\hline Squaxin Island & $8 / 4 / 2009$ & cal & 18.15 & 10.08 & & 7.03 & 10.08 & 0.03 & 0.00 & BLANK & & 761.7 & 100.0 & 9.2 & 9.5 & 0.3 \\
\hline
\end{tabular}

